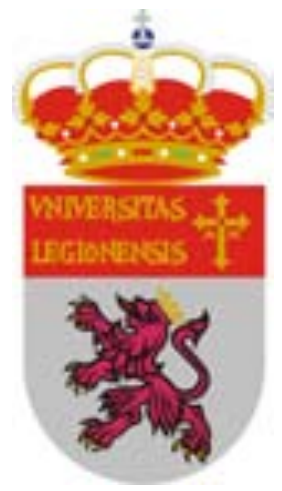

UNIVERSIDAD DE LEÓN

FACULTAD DE VETERINARIA

DEPARTAMENTO DE MEDICINA, CIRUGÍA Y ANATOMÍA VETERINARIA

\title{
INHIBICIÓN MEDIANTE ADALIMUMAB DE LA HIPERTROFIA REACTIVA DE LAS CÉLULAS DE MÜLLER EN UN CULTIVO ORGANOTÍPICO DE NEURORRETINA PORCINA
}

IVÁN FERNÁNDEZ BUENO

LEÓN 2011 



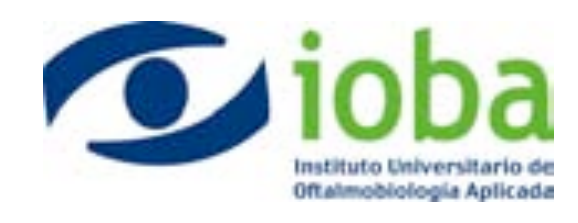

\section{INHIBICIÓN MEDIANTE ADALIMUMAB DE LA HIPERTROFIA REACTIVA DE LAS CÉLULAS DE MÜLLER EN UN CULTIVO ORGANOTÍPICO DE NEURORRETINA PORCINA}

Memoria de Tesis presentada por IVÁN FERNÁNDEZ BUENO para optar al grado de Doctor en Medicina y Cirugía Veterinaria por la Universidad de León

Directores:

Prof. Dr. JOSÉ MANUEL GONZALO ORDEN

Prof. Dr. JOSÉ CARLOS PASTOR JIMENO 



\section{INFORME DEL DIRECTOR DE LA TESIS}

El Dr. D. José Manuel Gonzalo Orden como Director de la Tesis Doctoral titulada "Inhibición mediante adalimumab de la hipertrofia reactiva de las células de Müller en un cultivo organotípico de neurorretina porcina" realizada por D. Iván Fernandez Bueno en el programa de doctorado Medicina y Cirugía Animal, informa favorablemente el depósito de la misma, dado que reúne las condiciones necesarias para su defensa.

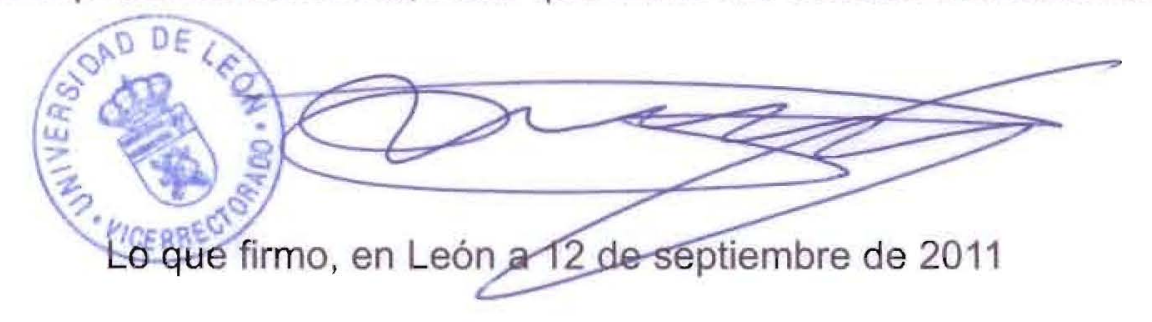





\section{INFORME DEL DIRECTOR DE LA TESIS}

El Dr. D. José Carlos Pastor Jimeno como Director de la Tesis Doctoral titulada "Inhibición mediante adalimumab de la hipertrofia reactiva de las células de Müller en un cultivo organotipico de neurorretina porcina" realizada por D. Iván Fernandez Bueno en el programa de doctorado Medicina y Cirugia Animal, informa favorablemente el depósito de la misma, dado que reúne las condiciones necesarias para su defensa.

Lo que firmo, en Valladolid a 5 de septiembre de 2011

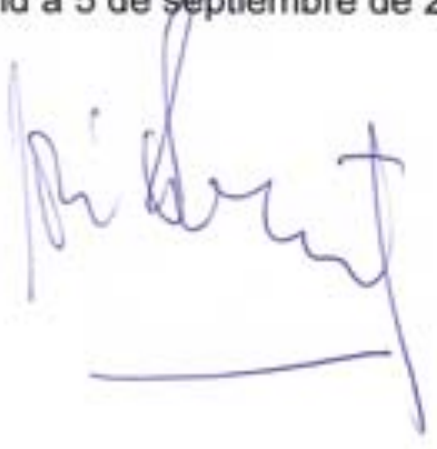




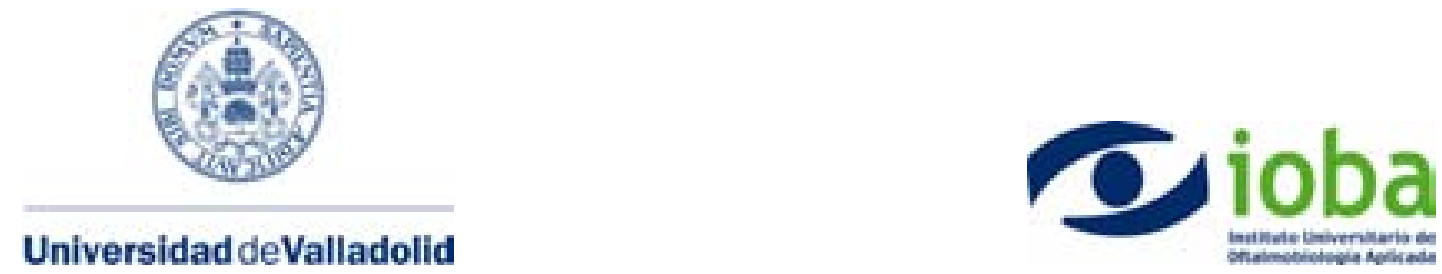

COMISIÓN DE INVESTIGACIÓN

La Comisión de Investigación del IOBA, en su reunión del 21 de julio de 2011, ha analizado su proyecto de tesis doctoral titulado:

"Inhibición mediante adalimumab de la hipertrofia reactiva de las células de Müller en un cultivo organotípico de neurorretina porcina", no encontrando ninguna objeción para poder ser remitido a la Comisión de Doctorado de la Universidad de León.

Y para que así conste se expide el presente certificado,

En Valladolid, a 21 de julio de 2011

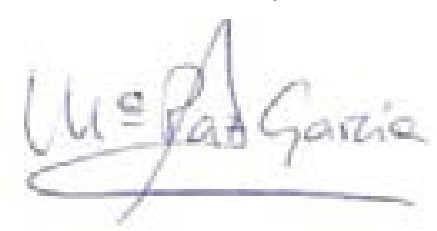

Fdo.: M a Paz García García

Secretaria de la Comisión de Investigación 

Desde estas líneas quiero expresar mi más sincero agradecimiento a todas aquellas personas que han contribuido en la culminación de la presente Tesis Doctoral. En particular, mis agradecimientos van dirigidos a las siguientes personas:

Al Prof. Dr. José Carlos Pastor Jimeno, director de esta Tesis, por haberme dado la oportunidad de formar parte del IOBA y de realizar este trabajo; por confiar en mí. Porque nunca ha cesado en su empeño de que esta línea de investigación saliera adelante, encontrando el apoyo científico y económico para poder desarrollarla adecuadamente. Por sus horas de dedicación y por brindarme la oportunidad de aprender a su lado.

Al Prof. Dr. José Manuel Gonzalo Orden, director de esta Tesis, por darme la oportunidad de trabajar a su lado, por su confianza y apoyo desde que era estudiante de veterinaria hasta el día de hoy, haciendo posible que llegase este momento.

Al Prof. Dr. Manuel José Gayoso porque desde el primer día puso a mi disposición todos sus conocimientos y las instalaciones del Dpto. de Biología Celular, Histología y Farmacología, para que este trabajo pudiera iniciarse y avanzar en la línea adecuada.

A Maite García por su inestimable contribución en el desarrollo de la parte experimental de este trabajo, y porque siempre me ha ayudado cuando lo he necesitado.

Al Prof. Dr. Nicolás Cuenca de la Universidad de Alicante, por permitirme complementar y clarificar partes de este trabajo, gracias a la magnífica aportación que supone el empleo de la microscopía confocal, así como un punto de vista alejado del ambiente oftalmológico. Sin olvidar el tiempo empleado por Laura Fernández en el procesamiento y adquisición de las imágenes, y en hacer más amenas mis estancias en Alicante.

Al Prof. Dr. Alfredo Corell por aportar unos notables conocimientos sobre la fisiología de los leucocitos sanguíneos y por permitirme llevar a cabo los estudios de citometría de flujo, con la inestimable colaboración del Dr. Roberto Reinoso y de Mario Martino.

A la Dra. Amalia Enríquez de Salamanca y a Carmen García por su aportación en el empleo del TNF $\alpha$ y en la puesta a punto de las técnicas de ELISA.

Al Dr. Javier Domínguez y al grupo que dirige en el Instituto Nacional de Investigación y Tecnología Agraria y Alimentaria (INIA, Madrid), por sus indicaciones y protocolos para la obtención y purificación de los monocitos porcinos. 
Al Dr. Girish K Srivastava por sus comentarios durante la planificación de los experimentos, y al resto del Grupo de Retina del IOBA por sus sugerencias en la interpretación de los resultados.

A la empresa Abbott Immunology (Madrid) por su interés en esta línea de investigación y por la donación de las muestras de Humira ${ }^{\circledR}$ utilizadas en este trabajo.

A todo el personal del matadero Justino Gutiérrez S.L. (Laguna de Duero, Valladolid), en especial a los veterinarios, por su inestimable colaboración en la obtención de las muestras porcinas utilizadas en la realización de este trabajo.

Al Prof. Dr. Daniel Albert por permitirme realizar una estancia en el Department of Ophthalmology and Visual Sciences de la University of Wisconsin (Madison, WI, EE.UU.), así como a todos los investigadores que se interesaron por implicarme en sus proyectos y por hacer que mi estancia fuera lo más productiva posible.

A todas las personas que componen el Dpto. de Biología Celular, Histología y Farmacología, en especial a Ignacio Alcalde por enseñarme la mayoría de los procesamientos histológicos utilizados en este trabajo, a Luis Santiago por la preparación de las muestras incluidas en epoxi-resina, y a Roberto Cantalapiedra, a Patricia Gallego y a Pablo Pérez por hacer más agradables las horas en el laboratorio.

A todos los integrantes del Dpto. de Medicina, Cirugía y Anatomía Veterinaria, en especial a la Prof. Dra. Mạ Asunción Orden y al Prof. Dr. José Manuel Gonzalo Cordero por ser los primeros en orientarme hacia la formación doctoral.

A toda la plantilla del IOBA por hacerme sentir uno más dentro del Instituto.

A mis padres y abuelos por su confianza y apoyo en el largo camino de la investigación, y por su amor incondicional.

A Patry por su cariño y por su aliento en el tramo final.

A mis amigos, Jose, Ros, Mesi, Borja, David, Marta y Alicia por haberme demostrado su interés y apoyo durante la realización de este trabajo.

A todos, muchas gracias.

Valladolid, septiembre de 2011

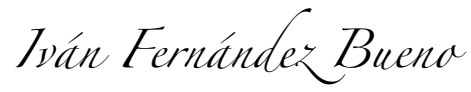


"Para una voluntad firme, nada es imposible, no hay fácil ni Bifúcil; fácil es lo que ya sabemos hacer, Bifúcil, lo que aún no hemos aprendido a hacer bien"

Bernarda Houssay 

A mis padres y abuelos 

Tudice

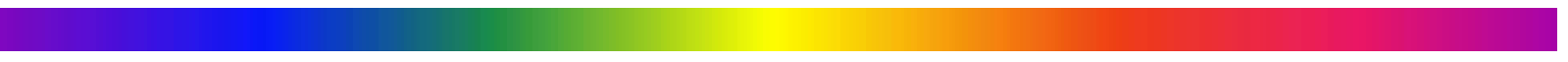



Lista de abreviaturas

Financiación 5

Difusian cientéfica 9

1. Gustificacion 15

2. Fipótesis de trabaja 23

3. Objetivas 27

4. Estada actual del tema 31

4.1. Tratamientos médicos y profilaxis de la vitreorretinopatía proliferante 33

4.2. Modelos experimentales de la vitreorretinopatía proliferante 35

4.2.1. Modelos in vivo 36

4.2.2. Modelos in vitro 42

4.3. Citoquinas implicadas en la patogénesis de la vitreorretinopatía proliferante ...... 45

4.3.1. El TNF $\alpha$ y sus receptores TNFR1 y TNFR2 46

4.3.2. Otras citoquinas secretadas por los macrófagos e implicadas en el desarrollo de la vitreorretinopatía proliferante 48

4.4. Agentes biológicos bloqueantes del TNF 51

4.4.1. Características 53

4.4.2. Utilización intraocular 55

5. Material y mêtado 59

5.1. Experimentos 61

5.2. Preparación y cultivo organotípico de los explantes de neurorretina porcina ...... 63

5.3. Extracción de los PBMCs y adición a los explantes en cultivo 67 
5.4. Extracción de los monocitos $\operatorname{CD} 14^{+}$y adición a los explantes en cultivo

5.4.1. Obtención de los PBMCs

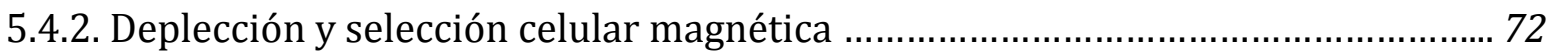

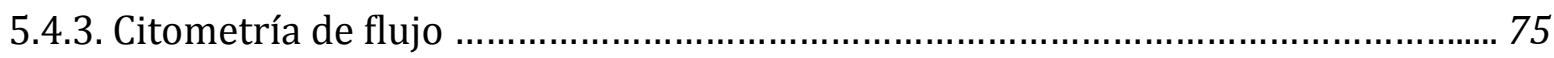

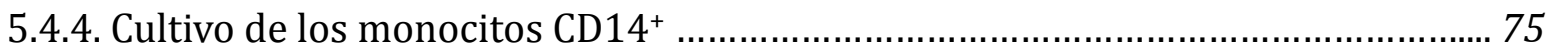

5.4.5. Determinación de los niveles de TNF $\alpha$ en el medio de cultivo ............................... 76

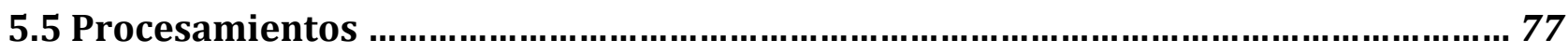

5.6. Técnicas de tinción histológica y citológica ........................................................ 79

5.7. Técnicas de inmunohistoquímica e inmunocitoquímica .................................. 81

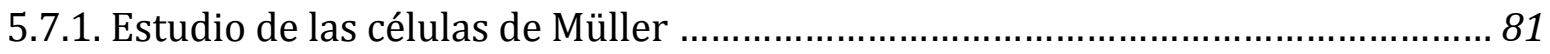

5.7.2. Estudio de los monocitos y de los macrófagos ............................................. 83

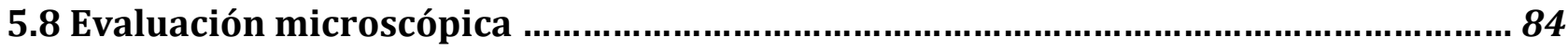

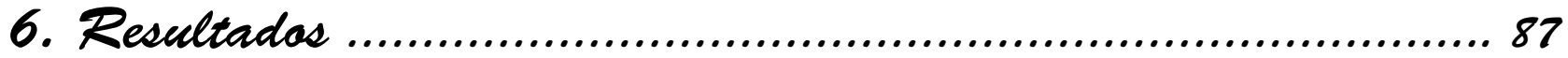

6.1. Caracterización histológica e inmunohistoquímica de la retina porcina recién

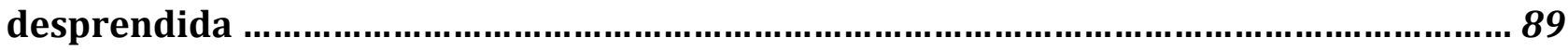

6.2. Caracterización histológica e inmunohistoquímica de los explantes

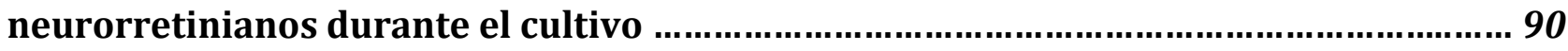

6.3. Caracterización histológica e inmunohistoquímica de los explantes neurorretinianos cultivados con PBMCs ...................................................................... 97

6.4. Caracterización inmunohistoquímica de los explantes neurorretinianos cultivados

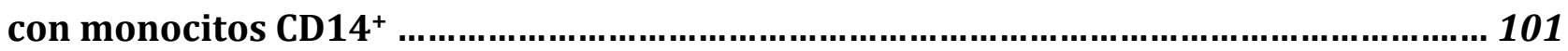

6.5. Caracterización inmunohistoquímica de los explantes neurorretinianos cultivados con TNF $\alpha$ 105

6.6. Caracterización inmunohistoquímica de los explantes neurorretinianos cultivados con adalimumab 108

6.7. Caracterización inmunohistoquímica de los explantes neurorretinianos cultivados con TNF $\alpha /$ adalimumab 109 


\subsection{Evaluación del espesor de los explantes neurorretinianos durante los}

7.1.1. Elección del modelo de cultivo organotípico de la neurorretina porcina

7.1.2. Elección del medio de cultivo retiniano

7.1.3. Elección de los métodos de obtención de los PBMCs

7.1.4. Elección de la GFAP y de la CRALBP como proteínas a evaluar en las células gliales 120

7.2. Discusión de los resultados 122

7.2.1. Puesta a punto y estandarización del cultivo organotípico de neurorretina porcina 122

7.2.2. Cultivo de los explantes neurorretinianos con PBMCs 125

7.2.3. Cultivo de los explantes neurorretinianos con monocitos CD14+ 132

7.2.4. Cultivo de los explantes neurorretinianos con TNF $\alpha$ 134

7.2.5. Cultivo de los explantes neurorretinianos con adalimumab y con $\mathrm{TNF} \alpha$ / adalimumab 137

7.3. Continuación de la línea de investigación 142

8. Canclusianes 145

9. Bibliagrafía 149

Anexal

Fernandez-Bueno I, Pastor JC, Gayoso MJ, Alcalde I, Garcia MT. Müller and macrophage-like cell interactions in an organotypic culture model of porcine neuroretina. Mol Vis 2008; 14:2148-56 

Lista de abreviaturas 

cols.: colaboradores

CRALBP (Cellular RetinALdehide-Binding Protein): proteína celular de unión al retinaldehido CD (Cluster of Differentiation): cúmulo de diferenciación

DMAE: Degeneración Macular Asociada a la Edad

DMEM (Dulbeco's Modified Eagle Medium)

DR: Desprendimiento de Retina

ED $_{50}$ (Effective Dose 50\%): dosis efectiva 50\%, dosis que produce el efecto deseado en el 50\% de los casos

EDTA (EthyleneDiamineTetraacetic Acid): ácido etilendiaminotetraacético

ELISA (Enzyme-Linked ImmunoSorbent Assay)

EPR: Epitelio Pigmentario de la Retina

FBS (Fetal Bovine Serum): suero bovino fetal

FDA (Food and Drug Administration): agencia del gobierno de los Estados Unidos responsable de la regulación de alimentos, suplementos alimenticios, medicamentos, cosméticos, aparatos médicos, productos biológicos y derivados sanguíneos

FPS (Fetal Porcine Serum): suero porcino fetal

GCL (Ganglion Cell Layer): capa de las células ganglionares

GFAP (Glial Fibrillary Acidic Protein): proteína glial fibrilar acídica

IFN (InterFeroN): interferón

HBSS (Hank's Balanced Salt Solution)

IgG1: inmunoglobulina G1

IGF (Insulin Growth Factor): factor de crecimiento insulínico

IL (InterLeuquin): interleucina

ILM (Inner Limiting Membrane): membrana limitante interna

INL (Inner Nuclear Layer): capa nuclear interna

IPL (Inner Plexiform Layer): capa plexiforme interna

IS (Inner Segments): segmentos internos de los fotorreceptores 
MIF (Macrophage migration Inhibitory Factor): factor inhibidor de la migración macrofágica NF (Nuclear Factor): factor nuclear

NFL (Nerve Fiber Layer): capa de las fibras del nervio óptico

OLM (Outer Limiting Membrane): membrana limitante externa

ONL (Outer Nuclear Layer): capa nuclear externa

OPL (Outer Plexiform Layer): capa plexiforme externa

OS (Outer Segments): segmentos externos de los fotorreceptores

PB (Phosphate Buffer): tampón fosfato

PBS (Phosphate Buffer Saline): tampón fosfato salino

PBMCs (Peripheral Blood Mononuclear Cells): células mononucleares de sangre periférica PDGF (Platelet-Derived Growth Factor): factor de crecimiento derivado de plaquetas

PF: paraformaldehido

PRP (Platelet-Rich Plasma): plasma enriquecido en plaquetas

ROCK (RhO-assoCiated protein Kinase)

RPMI (Roswell Park Memorial Institute medium)

SWC (SWine Cluster of differentiation): cúmulo de diferenciación porcino

TBS (Tris Buffered Saline)

TGF (Transforming Growth Factor): factor de crecimiento transformante

TNF (Tumor Necrosis Factor): factor de necrosis tumoral

mTNF: forma transmembrana del TNF

STNF: forma soluble del TNF

TNFR (Tumor Necrosis Factor Receptor): receptor del factor de necrosis tumoral STNFR: forma soluble del TNFR

VEGF (Vascular Endothelial Growth Factor): factor de crecimiento del endotelio vascular VRP: VitreoRretinopatía Proliferante 
Financiacion 

Esta línea de investigación ha contado con la financión de un Proyecto de Investigación en Biomedicina de la Junta de Castilla y León (Expediente: SAN/1052/VA17/05).

La financiación personal durante el desarrollo de este trabajo ha sido posible gracias a la Consejería de Educación de la Junta de Castilla y León, mediante la concesión de las siguientes ayudas:

1. Beca para la formación de personal investigador (FPI) de la Comunidad de Castilla y León, cofinanciada por el Fondo Social Europeo; convocadas por Orden EDU/1878/2006, de 23 de noviembre de 2006 (B.O.C. y L. de 27 de noviembre) y resueltas por Orden EDU/ 1165/2007, de 26 de junio (B.O.C. y L. de 28 de junio), para la realización del trabajo de investigación titulado "Interacciones entre células de Müller y macrófagos en cultivo organotípico de retina", bajo la dirección del Dr. José Carlos Pastor Jimeno en el Instituto Universitario de Oftalmobiología Aplicada (IOBA) de la Universidad de Valladolid.

2. Ayuda para la realización de estancias breves en centros de investigación nacionales o extranjeros en el año 2009; convocadas por Orden EDU/1947/2008, de 14 de noviembre de 2008 (B.O.C. y L. de 17 de noviembre) y resueltas por Orden EDU/939/2009, de 28 de abril de 2009 (B.O.C. y L. de 5 de mayo), en el Department of Ophthalmology and Visual Sciences, School of Medicine and Public Health, University of Wisconsin-Madison, Madison (Wisconsin), EE.UU., durante 12 semanas. 

Difusian cientifica 

Este trabajo ha dado lugar a los siguientes artículos científicos:

Fernandez-Bueno I, Pastor JC, Gayoso MJ, Alcalde I, Garcia MT. Müller and macrophage-like cell interactions in an organotypic culture model of porcine neuroretina. Mol Vis 2008; 14:2148-56. Índice Impacto 2008: 2,464.

Fernandez-Bueno I, Garcia-Gutierrez MT, Srivastava G, Gayoso MJ, Gozalo-Orden JM, Pastor JC. Adalimumab reduces the GFAP expression increased by TNF- $\alpha$ in an organotypic culture of porcine neuroretina. En preparación.

Este trabajo ha sido presentado en los siguientes congresos científicos:

1. Pastor JC, Fernández-Bueno I, Gayoso MJ. Modelo de Cultivo Organotípico de Retina Porcina. 83 Congreso de la Sociedad Española de Oftalmología (SEO). Las Palmas, septiembre 2007.

2. Fernández-Bueno I. Organotypic culture model of porcine neuroretina. IOBA Retina Workshop 2007. Valladolid, noviembre 2007.

3. Fernández-Bueno I, Pastor JC, Gonzalo JM, Gayoso MJ. Modelo de Enfermedades Retinianas: Cultivo Organotipico de Retina. XVI Congreso de la Sociedad Española de Cirugía Veterinaria. Zaragoza, abril 2008.

4. Fernandez-Bueno I, Pastor JC, Gayoso MJ, Alcalde I, Garcia MT. Müller Cells Modifications After Interact With Macrophage-Like Cells in an Organotypic Culture of Porcine Neuroretina. The Association for Research in Vision and Ophthalmology (ARVO) Annual Meeting. Fort Lauderdale (Florida, EE.UU.), abril 2008. 
5. Fernandez-Bueno I, Pastor JC, Gonzalo-Orden JM, Gayoso MJ. Retinal Diseases Model: Neuroretinal Organotypic Culture. The European Society of Veterinary Ophthalmology (ESVO) and The European College of Veterinary Ophthalmologist (ECVO) 2008 Meeting. Versailles (Francia), mayo 2008.

6. Fernández-Bueno I, Pastor JC, Gayoso MJ, Alcalde I, Garcia MT. Interacciones entre Células de Müller y Células Macrofágicas en Cultivo Organotípico de Neurorretina Porcina. V Congreso de Neurociencias de Castilla y León. Ponferrada, septiembre 2008.

7. Fernández-Bueno I. Neuroretinal Organotypic Culture as a Retinal Diseases Model. IOBA Retina Workshop 2008. Valladolid, noviembre 2008.

8. Fernandez-Bueno I, Pastor JC, Gayoso MJ, Garcia MT. Development of an Ex-Vivo Model of Retinal Diseases. The European Society of Veterinary Ophthalmology (ESVO) and The European College of Veterinary Ophthalmologist (ECVO) 2009 Meeting. Copenhague (Dinamarca), junio 2009.

9. Pastor JC, Fernandez-Bueno I, Gayoso MJ, Garcia MT, Corell A, Reinoso R, Enriquez A, García C. Neuroretinal reactive gliosis changes were not appreciable in the presence of macrophagelike cells that do not produce significant TNF $\alpha$ and/or IL-1b levels. Preliminary results. The Association for Research in Vision and Ophthalmology (ARVO) Annual Meeting. Fort Lauderdale (Florida, EE.UU.), mayo 2010.

10. Pastor JC, Fernandez-Bueno I, Garcia M, Gayoso M, Enriquez de Salamanca A. Exogenous TNFa addition early enhanced GFAP and ISB4 expression in an organotypic culture of porcine neuroretina. 10th EURETINA Congress. París (Francia), septiembre 2010.

11. Fernandez-Bueno I, Garcia M, Pastor JC, Gayoso MJ, Corell A, Reinoso R, Enriquez de Salamanca A, Garcia C. Porcine CD14+ monocytes did not secreted detectable TNF $\alpha$ and/or 
IL-1 $\beta$ levels in an organotypic culture of porcine neuroretina. Macrophages and Inflammation, Barcelona BioMed Conferences; BBVA Foundation-IRB Barcelona. Barcelona, octubre 2010.

12.Fernandez-Bueno I, MT Garcia-Gutierrez, MJ Gayoso, Pastor JC. Enhanced GFAP Expression Induced By Exogenous TNFa Could Be Diminished By Adalimumab In An Organotypic Culture Of Porcine Retina. The Association for Research in Vision and Ophthalmology (ARVO) Annual Meeting. Fort Lauderdale (Florida, EE.UU.), mayo 2011.

Este trabajo ha recibido los siguientes premios y distinciones:

1. Premio Dres. Galo y Gustavo Leoz a la mejor Comunicación de Investigación: "Modelo de Cultivo Organotípico de Retina Porcina" Pastor JC, Fernández-Bueno I, Gayoso MJ. 83 Congreso de la Sociedad Española de Oftalmología. Las Palmas, septiembre 2007.

2. Award for Best Poster presented at the 2008 Annual Meeting of the European Society of Veterinary Ophthalmology (ESVO) and the European College of Veterinary Ophthalmology (ECVO): “Retinal Diseases Model: Neuroretinal Organotypic Culture” Fernandez-Bueno I, Pastor JC, Gonzalo-Orden JM, Gayoso MJ. The European Society of Veterinary Ophthalmology (ESVO) and The European College of Veterinary Ophthalmologist (ECVO) 2008 Meeting. Versailles (Francia), mayo 2008.

3. Accesit al Premio Excma. Diputación de Valladolid al trabajo "Interacciones entre células de Müller y macrófagos porcinos en cultivo organotípico" Fernández-Bueno I, Pastor JC, Gayoso MJ, Alcalde I, García MT. Real Academia de Medicina y Cirugía de Valladolid. Valladolid, enero 2009. 

1. Gustificacion 

Los procesos de inflamación y reparación de la retina no son suficientemente conocidos a pesar de su extraordinaria trascendencia para el mantenimiento de la función visual. Se sabe, no obstante, que la respuesta inflamatoria exagerada conduce a graves alteraciones morfológicas, con una desestructuración retiniana, y por lo tanto a serias modificaciones funcionales, con pérdida de la función visual. Estos procesos de reparación pueden considerarse como una de las bases patogenéticas más importantes de una grave complicación de los desprendimientos de retina, denominada vitreorretinopatía proliferante (VRP).

La VRP sigue siendo la principal causa de fracaso de la cirugía del desprendimiento de retina $(D R)^{1}$, entidad que se presenta en un caso nuevo por cada 10.000 individuos/año, ${ }^{2}$ situándose la incidencia de la VRP entre el 5 y el 10\% de los casos en nuestro entorno. ${ }^{3}$ Esta patología tiene unos costes muy elevados, tanto a nivel económico como en términos sociales, y supone una pérdida severa de la función visual por parte del individuo. ${ }^{4}$ Además hay un problema añadido, y es que hasta la fecha no existe una profilaxis adecuada a pesar de los innumerables esfuerzos realizados por los investigadores a lo largo de los últimos treinta años.

Como se ha mencionado, la VRP está considerada como un proceso de inflamación y cicatrización exagerado, originado tras la rotura del tejido retiniano, y donde se producen proliferación celular, depósito de la matriz extracelular, remodelación tisular y formación de membranas contráctiles. ${ }^{5}$ Esta complicación se desarrolla en el contexto de una marcada respuesta inflamatoria y fibrótica, estando ligada, probablemente en muchos casos, a un ambiente genético propicio. ${ }^{6-8}$ La VRP también puede ser interpretada como el resultado de la acción de una cascada de citoquinas y factores de crecimiento sobre la retina, que han sido 


\section{1. qustificaciān}

detectados en concentraciones elevadas en muestras vítreas de pacientes con VRP.9, 10 Estos factores serían liberados por las interacciones entre las células propias de la retina, como las gliales y el epitelio pigmentario de la retina (EPR), y las de origen no retiniano, como los macrófagos, los linfocitos, los fibroblastos, las plaquetas y los polimorfonucleares, que llegan a la cavidad vítrea tras la rotura de la barrera hemato-retiniana, originada por el DR. ${ }^{11-14}$ Entre todas las células implicadas, merece la pena destacar el papel que parecen jugar las células gliales y los macrófagos en la patogenia de la VRP. ${ }^{15-17}$ En cualquier caso, la consecuencia final de esta patología es la desorganización intrarretiniana, con la formación, en ocasiones, de membranas epi y subretinianas, que al contraerse, provocan un DR traccional y la progresiva pérdida de la función visual. ${ }^{5,14}$

Las células de Müller son las principales células gliales de la retina de los vertebrados, siendo consideradas una glía radial especializada que se extiende por todo el espesor retiniano, contactando con los procesos y cuerpos neuronales. Asimismo, las células de Müller constituyen una unión anatómica y funcional con las neuronas retinianas, siendo esenciales en la creación y mantenimiento de la arquitectura neurorretiniana, en la supervivencia neuronal y en la regulación del procesamiento de la información visual. ${ }^{18,19}$ En condiciones patológicas, las células de Müller pueden actuar como moduladoras de la respuesta inmune e inflamatoria, y son capaces de fagocitar fragmentos de células retinianas y cuerpos extraños. ${ }^{20-23}$ Pero lo más destacable es que se vuelven "activas" o "reactivas" en respuesta a cualquier alteración patológica retiniana. Esta acción, llamada gliosis celular, es uno de los principales componentes de la compleja respuesta retiniana que se produce frente a estímulos patológicos. Su componente inespecífico más sensible, que puede ser utilizado como marcador celular precoz frente a un daño, es el aumento que exhiben los filamentos intermedios originados por la GFAP (del inglés, Glial Fibrillary Acidic Protein). ${ }^{24-26}$ En la VRP, las células de Müller proliferan bruscamente y en colaboración con células de tipo 
fibroblástico, probablemente derivadas del EPR, originan membranas fibrocelulares en ambas superficies retinianas, y sobre todo, son las principales responsables de los cambios intrarretinianos. ${ }^{14,27-30}$ Estas modificaciones que sufren las células de Müller no pueden ser consideradas como acciones beneficiosas para la retina, ya que las células están alteradas durante el proceso de remodelado, lo que tiene serias consecuencias para la fisiología retiniana. ${ }^{31}$ Por ello desde hace más de treinta años, se considera necesario inhibir los cambios que sufren estas células, lo que todavía no se ha conseguido de manera satisfactoria. $17,32-34$

Por su parte, los macrófagos son células extremadamente adaptables, capaces de modificar su comportamiento en respuesta a diversas señales provenientes de otras células o de la matriz extracelular. Juegan un papel crítico en el sistema inmune, bien actuando como células reguladoras o efectoras en la infección, el crecimiento tumoral y los procesos traumáticos. ${ }^{35}$ Los macrófagos poseen muchas funciones: como parte del sistema inmune innato pueden fagocitar microorganismos y células dañadas o muertas, y liberar varios tipos de citoquinas; y como parte del sistema inmune adquirido actúan como células presentadoras de antígenos, como células efectoras en procesos de lisis celular, y fagocitando a las células opsonizadas. ${ }^{36}$ Los macrófagos, ausentes en el tejido retiniano en condiciones fisiológicas, ${ }^{37}$ migran a la retina, desde el torrente circulatorio, tras la rotura de las barreras hematoretinianas, que se produce en los $\mathrm{DR},{ }^{11-14,} 38$ liberando potentes citoquinas proinflamatorias $\mathrm{y}$ proangiogénicas. A estos macrófagos infiltrantes se les atribuye un gran potencial destructivo en comparación con los macrófagos tisulares de la retina, la microglía, y pueden llegar a alterar la función retiniana. ${ }^{39,40}$ Se ha propuesto que la interacción entre los macrófagos y las células gliales es uno de los desencadenantes de la cascada que conduce al daño neuronal en diversas enfermedades neurodegenerativas, y que además, los macrófagos infiltrantes se asocian estrechamente, en el parénquima retiniano, con las células de Müller activas. ${ }^{39}$ Sin 


\section{Zustificacion}

olvidar, como se ha mencionado, que existen fuertes evidencias que apoyan que la inflamación, 5, 41, 42 y especialmente uno de sus componentes celulares, los macrófagos, juegan un papel importante en el desarrollo de la VRP. ${ }^{14,38,43-49}$

En estas interacciones entre los macrófagos y las células de Müller, parece jugar un papel fundamental una de las principales citoquinas proinflamatorias secretadas por los macrófagos, el TNF $\alpha$ (del inglés, Tumor Necrosis Factor). ${ }^{39}$ Esta proteína tiene un amplio rango de funciones biológicas, y está implicada en procesos inflamatorios, proliferativos y de muerte celular. ${ }^{50}$ Las alteraciones en la regulación de la producción de este factor pueden originar la activación de las células inmunes y la consiguiente cronicidad de la respuesta inflamatoria, originando un daño tisular. ${ }^{51}$ Además, se sabe que en el sistema nervioso central, el TNF $\alpha$ está directamente implicado en la desmielinización y en la degeneración axonal. ${ }^{52}$ Esta citoquina se presenta, y juega un papel fundamental, en gran variedad de enfermedades intraoculares como las uveítis, algunas degeneraciones retinianas hereditarias, y el glaucoma. ${ }^{53-59}$ Además, en la VRP, están aumentados los niveles intraoculares de $\mathrm{TNF} \alpha{ }^{10,60,61}$ pudiendo unirse a sus receptores en las células de Müller, y probablemente activandolas. ${ }^{39,62}$ Por último, un reciente estudio del Grupo de Retina del IOBA ha descrito un SNP (del inglés, Single Nucleotide Polimorphism) en el locus del TNF asociado con la VRP. ${ }^{8}$

La confirmación del TNF $\alpha$ como posible diana terapéutica en el tratamiento de la VRP abre el camino a la utilización de novedosas opciones terapéuticas, aún por explorar. En este sentido, durante los últimos años se ha estudiado la regulación y la supresión del TNF $\alpha$ en diversas enfermedades inflamatorias oculares, mediante la utilización de varios agentes biológicos bloqueantes del TNF.63-70 Entre ellos, se ha utilizado el adalimumab (Humira ${ }^{\circledR}$ ), un anticuerpo monoclonal anti-TNF totalmente humanizado. Este fármaco se emplea satisfactoriamente en el tratamiento de varias enfermedades inflamatorias sistémicas, como la 
artritis reumatoide y la enfermedad de Crohn, y progresivamente, ha ido probando su efectividad en el control de determinadas inflamaciones oculares. ${ }^{69-71}$

No obstante, a pesar de la importancia que aparentan tener las células de Müller y los macrófagos, mediante interacciones vía TNF $\alpha$, en el desarrollo de la VRP, y la disponibilidad de alternativas terapéuticas emergentes, la bibliografía al respecto es relativamente escasa, y los datos que se tienen sobre los mecanismos celulares implicados en la activación, control del crecimiento y de la apoptosis, en la migración y en la recirculación de las células inflamatorias en la retina son muy incompletos. ${ }^{45,72,73}$ Así mismo, los procesos que desencadenan la lesión tisular retiniana, inducidos por las células inflamatorias, son en gran parte desconocidos, y por lo tanto, la posibilidad de controlarlos farmacológicamente no es fácil. ${ }^{74,75}$ Unido al hecho de que cualquiera de los modelos previamente descritos para el estudio de la VRP presentan diferentes problemas que los hacen poco extrapolables, ${ }^{76}$ y que en los seres humanos, solo de forma excepcional, se tiene acceso directo a los cambios iniciales que acontecen tras un DR. Todo ello puede explicar porque se ha avanzado relativamente poco en este terreno.

Así pues, antes de iniciar estudios clínicos, es necesario recurrir a un modelo experimental, que simulando adecuadamente las condiciones patológicas, permita estudiar al conjunto de las células retinianas como una unidad, reproduciendo las interacciones que acontecen tras un DR, lo que permitiría llevar a cabo estudios experimentales, y analizar los resultados potenciales de las nuevas terapias oculares en la VRP. Este tema constituye un hecho relevante ya que otras aproximaciones terapeúticas y/o profilácticas, desarrolladas a lo largo de los últimos treinta años, han fracasado. ${ }^{2,5}$ 

2. Fipátesis de trabaja 

Las interacciones entre los macrófagos y las células de Müller retinianas, mediadas por el $\mathrm{TNF} \alpha$, incrementan la hipertrofia reactiva que sufren estas células tras un desprendimiento de retina, y pueden facilitar las modificaciones intrarretinianas que se han observado en algunos pacientes con vitreorretinopatía proliferante. La utilización de agentes biológicos bloqueantes del TNF reduce los cambios glióticos descritos, constituyendo una aproximación para el tratamiento o la profilaxis de esta patología.

Partiendo de un modelo de cultivo organotípico de neurorretina de cerdo, se puede desarrollar un modelo in vitro que simula los cambios celulares asociados con la vitreorretinopatía proliferante, y que permite estudiar las interacciones entre las células de Müller y los macrófagos o las citoquinas secretadas por éstos. 

3. Objetivas 

El objetivo general de este trabajo es analizar el papel que juegan las células macrofágicas en el incremento de la respuesta gliótica por parte de las células de Müller, probablemente ligada a la acción del $\mathrm{TNF} \alpha$, y evaluar el efecto potencial que pudieran tener los agentes biológicos bloqueantes del TNF sobre dicha respuesta, en un modelo de cultivo organotípico de neurorretina porcina.

Los objetivos específicos son:

- Poner a punto y estandarizar un modelo de cultivo organotípico de neurorretina porcina, inicialmente descrito por Winkler y cols. (2002). ${ }^{77}$

- Caracterizar las variaciones espontáneas que sufre el tejido retiniano a lo largo del cultivo, y en concreto, las células de Müller, mediante el estudio de las proteínas implicadas en la gliosis reactiva.

- Analizar las modificaciones que sufren las células de Müller en presencia de leucocitos o de monocitos $\mathrm{CD}_{14}{ }^{+}$, obteniendo ambas fracciones celulares a partir de sangre periférica porcina.

- Evaluar las variaciones que sufren las células de Müller en presencia de TNF $\alpha$ exógeno, de adalimumab (Humira ${ }^{\circledR}$ ), agente antagonista del TNF, o de ambos. 



\section{Estada actual}

del tema 



\subsection{Tratamientos médicos y profilaxis de la}

\section{vitreorretinopatía proliferante}

Durante las últimas décadas se han probado numerosas terapias médicas para el tratamiento de la VRP, pero muchas de ellas revelaron serios efectos secundarios, y solo unas pocas llegaron a ser utilizadas en ensayos clínicos. ${ }^{5,78}$ Estos tratamientos estaban basados, principalmente, en la inhibición de la proliferación celular y en impedir la contracción de las membranas fibrocelulares desarrolladas en la VRP, siendo los más destacables, los siguientes:

- Corticosteroides: se han empleado la triamcinolona, la dexametasona y otros. Algunos han sido probados en ensayos clínicos, ${ }^{78-81}$ pero muchos de los resultados han sido insatisfactorios, ${ }^{78,81}$ pudiendo tener utilidad potencial el uso de acetónido de triamcinolona únicamente como adyuvante de la cirugía. ${ }^{82}$

- Agentes antiproliferativos: el 5-fluorouracilo ha sido uno de los más utilizados en humanos, ${ }^{83}$ pero sus múltiples efectos secundarios y las dudas acerca de su eficacia han limitado su uso en la clínica. La colchicina ${ }^{84}$ y la daunomicina, ${ }^{85,86}$ también se han utilizado sin que se apreciaran signos clínicos ni angiográficos de toxicidad, pero tampoco se observó una clara mejoría en los resultados. ${ }^{87}$ No se ha podido comprobar su eficacia en el tratamiento de la VRP ya establecida, ${ }^{88}$ y desde luego se trata de fármacos que no están exentos de efectos adversos, ${ }^{89}$ por lo que el interés en esta aproximación terapéutica ha decaído en los últimos años.

- Anticoagulantes: se han utilizado la heparina ${ }^{90}$ y la heparina de bajo peso molecular, ${ }^{91}$ para prevenir la formación de fibrina. Inicialmente se describió que la combinación de heparina de bajo peso molecular con 5-fluorouracilo, como profilaxis ante el posible desarrollo de una VRP tras la realización de una vitrectomía o de una cirugía para reaplicar la retina, reducía la 
incidencia de la VRP postoperatoria, ${ }^{92}$ sin embargo, estudios posteriores no recomiendan su utilización en estos casos. ${ }^{93}$ Asimismo, esta terapia no aumenta la tasa de éxito de la cirugía vitreorretiniana en los casos de una VRP preoperatoria. 88

- Irradiación con electrones: se encontraron resultados experimentales satisfactorios, ${ }^{94}$ pero en seres humanos fueron decepcionantes. ${ }^{95}$

- Antioxidantes: la N-acetilcisteína demostró eficacia para inhibir el desarrollo de la VRP solo en modelos experimentales. ${ }^{96}$

- Otras opciones terapéuticas: principalmente basadas en la utilización de agentes con acciones antiproliferativas, dirigidos hacia la regulación de los factores de crecimiento implicados en la patogenia de la VRP. Entre ellos, la IL4 (del inglés, InterLeuquin), que bloquea los mediadores de la inflamación y la proliferación de los macrófagos activados; ${ }^{97}$ los antagonistas del calcio, como el nilvadipino, que impiden la síntesis del ADN; ${ }^{98}$ el taxol, que estabiliza los microtúbulos e inhibe la replicación, la migración y la concentración de fibroblastos, por tanto reduce la incidencia de los DR traccionales que aparecen en la VRP; ${ }^{99}$ la hipertermia, que suprime la proliferación celular, por lo tanto inhibe la proliferación de las células del EPR; ${ }^{100}$ el IFN $\gamma$ (del inglés, InterFeroN), que reduce el efecto mitogénico de los fibroblastos; ${ }^{101}$ el trapidil, antagonista específico del PDGF (del inglés, Platelet-Derived Growth Factor), que puede controlar la proliferación de las células gliales; ${ }^{102}$ e inhibidores de la adhesión celular, cuyo principal representante son las desintegrinas. ${ }^{103}$

Además de los efectos que puedan tener estas sustancias, otro punto importante a tener en cuenta es que los conocimientos referentes a su farmacocinética, tras la inyección en el interior del globo ocular, son escasos. Uno de los problemas que presentan es su corta vida media, ${ }^{104}$ por ello se están llevando a cabo estudios, encaminados a conseguir una liberación 
controlada de estos fármacos que asegure una elevada vida media en el globo ocular, ${ }^{105}$ reduciendo sus concentraciones y, por lo tanto, sus efectos secundarios. ${ }^{106,107}$ Se han barajado posibles vectores, como las micropartículas o microesferas cargadas; ${ }^{108-110}$ el uso de aceite de

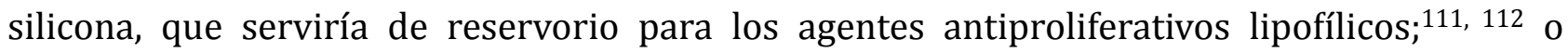
combinaciones farmacológicas, destacando el uso conjunto de 5-fluorouracilo y corticosteroides, que ralentizan la hidrólisis de estos compuestos y, por tanto, aumentan su vida media. ${ }^{113}$

Todas estas opciones abrieron un gran abanico de posibilidades teóricas para obtener un tratamiento eficaz frente a la VRP, sin embargo, el efecto de la mayoría de estas sustancias está basado, en muchos de los casos, en estudios in vitro y sus efectos en humanos todavía hoy son completamente desconocidos, por lo que a pesar de los avances observados en otros campos de la oftalmología en los últimos años, las estrategias terapéuticas y la frecuencia de la VRP siguen siendo las mismas que a principios de los años ochenta. La cirugía es el único tratamiento del que se dispone actualmente, no superando las tasas de reaplicación retiniana el $80 \%$ en los casos leves, y no alcanzando el 30\% en los casos graves. Pero más allá de los resultados anatómicos, todos los pacientes que desarrollan una VRP tienen un pronóstico funcional muy poco alentador. ${ }^{114}$

\subsection{Modelos experimentales de la vitreorretinopatía}

\section{proliferante}

Como ya se ha comentado, en los seres humanos solo en contadas ocasiones se pueden estudiar los cambios iniciales que suceden tras un DR, siendo necesario recurrir a modelos que simulen esta enfermedad. Se han descrito múltiples modelos in vivo, sin que haya uno 
plenamente satisfactorio, presentando cada uno de ellos determinadas limitaciones, ${ }^{76} \mathrm{y}$ dentro de los modelos in vitro, las técnicas de cultivos celulares no reproducen de forma adecuada las interacciones entre las células de un tejido relativamente complejo, como es la retina. ${ }^{115}$ Así pues, la mejor opción para el estudio de los cambios celulares asociados con la VRP, pudiera ser el desarrollo de un modelo de cultivo organotípico de todo el tejido retiniano, o al menos de la neurorretina, de tal manera que se pueda estudiar al conjunto de las células retinianas como una unidad, ${ }^{116}$ reproduciendo las interacciones que acontecen entre éstas tras un DR y permitiendo su manipulación mediante la adición de diferentes agentes, como células o factores implicados en la VRP, para intentar asemejar el comportamiento celular en el modelo con el que acontece en los humanos.

\subsubsection{Modelos in vivo}

En la bibliografía aparecen descritos más de veinticinco modelos in vivo de VRP, que han sido diseñados para el estudio de la patogénesis de esta enfermedad y de sus posibles terapias. Generalmente, los modelos están basados en la adición de células o factores, previamente encontrados en la VRP, y frecuentemente incluyen otras manipulaciones quirúrgicas, como la lensectomía, la vitrectomía o ambas. Los modelos más utilizados han sido los que incluyen la inyección intravítrea de fibroblastos ${ }^{117-124}$ o de células del EPR, ${ }^{125}$ y el animal más frecuentemente elegido ha sido el conejo.

Las especies animales utilizadas en los modelos de VRP se han escogido dependiendo de la idoneidad del animal para el procedimiento y de la facilidad para llevar a cabo el experimento. Entre ellas destacan: 
- Primates no humanos: varios investigadores han trabajado en estos modelos, ${ }^{126-128}$ pero actualmente son poco utilizados, debido a cuestiones éticas y a los altos costes experimentales.

- Lagomorfos: los conejos se han utilizado regularmente en estos experimentos por la facilidad para trabajar con ellos, ya que permiten llevar a cabo manipulaciones intraoculares sin originar daños en el cristalino o la retina, y a que, a pesar de la carencia de fóvea, los desprendimientos que se producen en su área medular simulan un DR que podría asemejarse al del humano, originándose posteriormente cambios característicos de la VRP.76

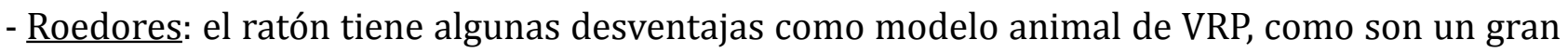
tamaño relativo del cristalino y un pequeño volumen vítreo, sin embargo, la disponibilidad de varias estirpes genéticamente modificadas supone una ventaja significativa. Además, un modelo reproducible en ratón permitiría estudiar el trasfondo genético de la patogénesis de la VRP, mediante la comparación de múltiples cepas endogámicas, facilitando la evaluación de fármacos candidatos para su tratamiento. ${ }^{129}$

- $\underline{\text { Suidos: }}$ los modelos desarrollados en cerdo reproducen, de manera muy cercana al ser humano las lesiones que caracterizan a la VRP anterior y posterior. Además, existe la ventaja añadida de que la retina del cerdo es muy similar a la del ser humano, con una densidad de bastones similar y una alta densidad total de conos, ${ }^{130-132}$ y que el tamaño del globo ocular permite llevar a cabo técnicas quirúrgicas complejas. ${ }^{130,133}$

\section{Modelos basados en inyecciones celulares:}

- En estos modelos se han utilizado mayoritariamente conejos pigmentados, inyectándose un amplio abanico de tipos celulares, en ocasiones, combinados con diferentes procedimientos quirúrgicos: 
- Inyección intravítrea de fibroblastos autólogos: ${ }^{124,134}$ los cambios asociados con la VRP se originan en torno a las cuatro semanas, haciéndose más marcados al aumentar el número de células inyectadas.

- Inyección intravítrea de fibroblastos homólogos: ${ }^{117,119,120}$ aparecen cambios asociados con la VRP entre las dos y las cuatro semanas.

- Inyección intravítrea de células endoteliales, condrocitos o células embrionarias: ${ }^{118}$ cualquiera de los tipos celulares originan el desarrollo de cambios asociados con la VRP, apareciendo éstos entre las dos y las cuatro semanas.

- Inyección de fibroblastos en ojos vitrectomizados: ${ }^{135}$ se requiere un reducido número de células para el desarrollo de cambios asociados con la VRP a las dos semanas.

- Lensectomía e inyección de fibroblastos en ojos vitrectomizados: ${ }^{136}$ se originan cambios asociados con la VRP a los diez días, pero el procedimiento quirúrgico es complejo en estos animales.

- Compresión vítrea mediante gas, para producir colapso vítreo, e inyección intravítrea de fibroblastos homólogos: ${ }^{122,137,138}$ aparecen cambios asociados con la VRP entre la primera y la cuarta semana, asemejándose bastante a los descritos en humanos.

- Inyección intravítrea de células del EPR autólogas: ${ }^{125}$ aparecen modificaciones asociadas con la VRP en dos semanas, con características similares a las originadas por fibroblastos.

- Inyección intravítrea de células del EPR homólogas: ${ }^{118}$ los cambios originados son muy dependientes del número de células inyectadas, apareciendo entre las dos y las cuatro semanas.

- Inyección intravítrea de macrófagos activados: ${ }^{139,140}$ los macrófagos inician la migración y la proliferación celular en el vítreo, apareciendo cambios entre las tres y las cinco semanas. 
- Vitrectomía, retinotomía, crioterapia e inyección de PRP (del inglés, Platelet-Rich Plasma): 141-143 los cambios asociados con la VRP aparecen a los doce días, siendo similares a los descritos en humanos.

- Vitrectomía parcial e inyección intravítrea de células del EPR y de PDGF: ${ }^{76}$ aparecen cambios asociados con la VRP a las cuatro semanas, dependiendo el grado de ésta del número de células inyectadas.

- Creación de agujeros retinianos e inyección intravítrea de IL1ß: ${ }^{144}$ reproduce los efectos de los mediadores inflamatorios en la patogénesis de la VRP en cuatro semanas.

- Incisión en pars plana e inyección de leucocitos mononucleares o monocitos adherentes: ${ }^{145}$ el grado de la VRP depende del número de monocitos inyectados, se desarrolla entre la primera y la cuarta semana.

- Utilizando otros animales de experimentación:

- Inyección intravítrea de células del EPR humano: ${ }^{146}$ desarrollado en conejos New Zealand White, aparecen cambios asociados con la VRP entre la primera y la cuarta semana, con la formación de membranas epirretinianas similares a las encontradas en la VRP humana.

- Vitrectomía parcial, retinotomía, crioaplicaciones e inyección de PRP: ${ }^{133}$ desarrollado en lechones, aparecen cambios asociados con VRP entre la primera y la tercera semana, los cambios observados son más relevantes que en los modelos previos basados solamente en la inyección de PDGF. 


\section{Modelos basados en la manipulación quirúrgica:}

Estos modelos se basan en la combinación de diferentes procedimientos quirúrgicos asociados con el desarrollo de la VRP.

- Utilizando diferentes estirpes de ratones:

- Lensectomía y vitrectomía: ${ }^{147}$ aparecen cambios asociados con una VRP anterior entre la primera y la segunda semana, originando una tracción vitreorretiniana posterior.

- Lensectomía, DR y raspado del EPR: ${ }^{148}$ a los dos meses las células del EPR se mantienen en el espacio subretiniano, no apareciendo migración a la cavidad vítrea.

- Lensectomía, vitrectomía y DR periférico: ${ }^{149}$ se originan membranas fibrocelulares entre la segunda y la octava semana.

- Utilizando primates no humanos:

- Trauma: ${ }^{126-128}$ aparecen cambios asociados con una VRP traumática entre la octava y la decimotercera semana. La mayor crítica hacia estos modelos es que no se parecen a la VRP que se produce tras un DR regmatógeno, ya que se efectúan heridas perforantes en la pared del globo ocular, lo que permite el acceso de fibroblastos esclerales y que se originen intensas hemorragias vítreas.

\section{Otros modelos:}

- Utilizando conejos pigmentados:

- Inyección intravítrea o subretiniana de dispasa: ${ }^{150,151}$ suele complicarse con una hemorragia vítrea. Aparecen cambios asociados con la VRP entre la tercera y la décima semana. 
- Inyección intravítrea de células del EPR modificadas: ${ }^{148}$ se inyectan células del EPR modificadas genéticamente para sobreexpresar diferentes factores de crecimiento, permitiendo estudiar el efecto de cada factor individualmente. Aparecen cambios asociados con la VRP entre la primera y la segunda semana.

- Inyección intravítrea o subretiniana de vectores adenovirales expresando diferentes factores de crecimiento $:^{152}$ los adenovirus transducen las células del EPR empezando a expresar el factor de interés, aparecen cambios asociados con la VRP entre la primera y la cuarta semana.

- Utilizando ratones:

- Inyección intravítrea de dispasa: ${ }^{129}$ mejor modelo que en conejo ya que se reduce el sangrado vítreo.

- Expresión de PDGF en los fotorreceptores: ${ }^{153-155}$ usando un promotor de la rodopsina se origina la expresión transgénica de PDGF por parte de los fotorreceptores. Se origina un DR traccional espontáneo entre el tercer y el noveno mes de vida de los animales, debido a la sobreexpresión de PDGF.156

\section{Problemas de los modelos in vivo:}

El principal problema que acarrean estos modelos es que existen importantes diferencias clínicas y anatomopatológicas entre los modelos de VRP en animales y la enfermedad humana. Estas diferencias deben ser tenidas en cuenta y limitan la relevancia directa de los modelos sobre la clínica humana.

Los primeros modelos de VRP utilizaban frecuentemente inyecciones de fibroblastos dérmicos de conejo para iniciar la VRP, sin embargo, los fibroblastos dérmicos no forman parte de la patogénesis de la VRP humana, siendo los modelos posteriores basados en 
inyecciones de células del EPR más parecidos. La progresión de la VRP en los modelos es mucho más rápida que en humanos e incluye gran cantidad de células, por lo que la inhibición completa de la VRP experimental es difícil de conseguir. Por otra parte, las técnicas quirúrgicas empleadas en los modelos implican la posibilidad de que el número de leucocitos infiltrantes sea mínimo, y por tanto los niveles de citoquinas secretadas por éstos, asociadas al desarrollo de la VRP, sean bajos, salvo en los modelos basados en el trauma del globo ocular. Por último, no conviene olvidar que los animales de experimentación comúnmente utilizados, como el conejo, la rata y el ratón, poseen considerables diferencias anatómicas, a nivel retiniano, en comparación con los seres humanos; y otros animales, como los primates no humanos y el cerdo, que cumplen con los requisitos anatómicos, acarrean problemas relacionados con su manejo y su mantenimiento. ${ }^{141,157-159}$

\subsubsection{Modelos in vitro}

Se han utilizado modelos in vitro de VRP principalmente como medio de aproximación al estudio de la proliferación celular vítrea, de la contracción retiniana y del papel que puedan jugar las células del EPR en el desarrollo de la VRP. La ventaja de estos modelos es que las células pueden ser observadas directamente bajo condiciones estandarizadas. Además, permiten ser manipulados mediante la adición de diferentes agentes, como los farmacológicos, intentando modificar el comportamiento celular. En definitiva, los sistemas in vitro permiten analizar el comportamiento de poblaciones celulares definidas, estando preparados para una posible manipulación experimental. ${ }^{160}$ 


\section{Cultivos celulares:}

Se han realizado diversos trabajos para analizar el papel que pueden jugar aisladamente diferentes tipos celulares en el desarrollo de la VRP, destacando:

- Cultivo de células del EPR: se han utilizado para estudiar algunos efectos relevantes de la VRP, incluyendo la proliferación celular, la apoptosis, la migración, y la unión de las células a las matrices extracelulares y la posterior contracción de éstas. Las células del EPR se han aislado de ojos humanos procedentes de donantes, así como de ojos enucleados de primates no humanos, conejos, vacas, cerdos, ratas y ratones, para su posterior utilización in vitro o para ser inyectadas intraocularmente, con el fin de inducir una VRP experimental. ${ }^{161,162}$

- Cultivo de células de Müller: aisladas a partir de retinas humanas y porcinas, se ha descrito el papel que estas células juegan en los desórdenes fibrocontráctiles de la retina, evidenciando que funcionan como una célula efectora en los DR traccionales asociados con la VRP.163-166

- Cultivo del vítreo: empleando explantes vítreos, procedentes de ojos humanos enucleados o vitrectomizados, se han estudiado procesos de proliferación y contracción celular. Sobre vítreo bovino extraído y posteriormente dializado, se han cultivado diferentes tipos celulares, comparando los efectos que estas células originan en la estructura vítrea, y describiendo la contracción del colágeno vítreo mediada por células del EPR, que parece ser similar a la observada en humanos con VRP. ${ }^{160}$ Sobre vítreo humano, obtenido de vitrectomías de pacientes que habían desarrollado DR, VRP o hemorragia vítrea, se han cultivado células de Müller porcinas, asociando la presencia de factores como el IGF (del inglés, Insulin Growth Factor) y el PDGF, presentes en las muestras vítreas, con la acción de fuerzas contráctiles por parte de las células de Müller. ${ }^{167}$ 
No obstante, aunque las técnicas de cultivos son muy útiles para deteminar el comportamiento de un tipo celular en concreto, no reproducen de forma adecuada las interacciones entre las células de un tejido relativamente complejo, como es la retina, por lo que los hallazgos en estos modelos deben ser interpretados con cautela.

\section{Cultivos organotípicos:}

Los sistemas de cultivo de retina comenzaron a desarrollarse en la década de 1920, utilizando retinas de embriones de pollo sobre coágulos de plasma, ${ }^{168}$ en los años posteriores, se aplicó dicha técnica con las retinas de mamíferos. ${ }^{169}$ En la década de 1950, Trowell desarrolló el método de cultivo sobre membrana, ${ }^{170}$ en el cual el tejido era colocado en una membrana porosa sobre una rejilla metálica, y mantenido en una interfase aire-medio. Esta técnica, colocando la superficie vítrea de la retina en contacto con la membrana, fue utilizada para el estudio de las dinámicas celulares en explantes retinianos durante las siguientes tres décadas. ${ }^{171-174}$ Finalmente en 1989, Caffé y cols. ${ }^{175}$ desarrollaron un método en el cual la retina neural era colocada, con los fotorreceptores hacia abajo, en soportes formados por filtros de nitrocelulosa y rejillas de poliamida. Desde entonces, los cultivos organotípicos de retinas de mamíferos, principalmente de murinos, bovinos, suinos y lagomorfos, han sido utilizados en numerosos estudios, que han permitido describir la diferenciación, bajo condiciones controlables, de retinas pre y postnatales de fase temprana; ${ }^{175-177}$ han aportado importantes conocimientos acerca de los procesos patofisiológicos de las enfermedades retinianas degenerativas; ${ }^{178-183}$ y se han mostrado útiles para testar sustancias terapeúticas, 179, 180, 184 para examinar el papel de diversos factores de crecimiento sobre las células retinianas, ${ }^{185-188}$ para determinar la toxicidad potencial de varias sustancias, ${ }^{189}$ y para perfeccionar la utilización de células madre como terapia celular. ${ }^{190}$

Los sistemas de cultivo organotípico de retina aplicados al estudio de la VRP, se han llevado a cabo con retinas bovinas, sembrando sobre los explantes células del EPR humano y 
fibroblastos bovinos, procedentes de la cápsula de Tenon, para simular las características de las membranas epirretinianas encontradas en los primeros estadíos de la VRP,182 observando como las células sembradas se unen a la superficie retiniana, ejerciendo fuerzas traccionales que provocan pliegues superficiales y profundos en el tejido retiniano. Igualmente, mediante el empleo de un cultivo organotípico de retina murina, se determinó que el PDGF juega un papel importante en la promoción de la proliferación de las células gliales y en su asociación con la contracción retiniana. ${ }^{160,191,192}$

\subsection{Citoquinas implicadas en la patogénesis de la}

\section{vitreorretinopatía proliferante}

La señal para el desarrollo de los dramáticos cambios que se detectan en la VRP, parece estar relacionada, a nivel celular, con la pérdida de contacto y de señalización entre el EPR y los fotorreceptores, que sucede tras el DR. ${ }^{193}$ Alternativamente, puede ser considerada como la respuesta a múltiples señales a nivel molecular, destacando la acción que parecen llevar a cabo varias citoquinas, como el $\mathrm{TNF} \alpha$, secretado por las células inflamatorias llegadas a la zona lesionada, ${ }^{161}$ jugando un papel importante como mediador en la activación del EPR y de las células de Müller;39, 62, 194 el TGF $\beta$ (del inglés, Transforming Growth Factor) que es un colaborador fundamental en la fibrosis tisular; y el PDGF, que es un importante mitógeno, quimioatrayente y mediador en la contracción celular, ${ }^{153,195-198}$ y que induce en las células de Müller, junto con miembros de la familia del IGF, la capacidad de generar fuerzas traccionales. 164,167 
Otras citoquinas que parecen tomar parte en la patogenia de la VRP, y de las que se han encontrado concentraciones elevadas en muestras provenientes de pacientes con VRP, son la IL6 y 8, ${ }^{48,199,} 200$ el NFkB (del inglés, Nuclear Factor), ${ }^{201}$ las MMP2 y 9 (del inglés, Matrix Metallo Proteinase), 202, 203 el IFN $\gamma^{204,205}$ el HGF (del inglés, Hepatocyte Growth Factor), ${ }^{206}$ el EGF (del inglés, Epidermal Growth Factor), ${ }^{207}$ el FGF2 (del inglés, Fibroblast Growth Factor), ${ }^{9,}$ 200, 208, 209 el MCP1 (del inglés, Monocyte Chemotactic Protein) ${ }^{210}$ y el CTGF (del inglés, Connective Tissue Growth Factor), ${ }^{211}$ aunque en estos momentos se estima que juegan papeles menos importantes que las tres citoquinas mencionadas anteriormente.

\subsubsection{El TNF $\alpha$ y sus receptores TNFR1 y TNFR2}

El TNF $\alpha$ es una citoquina producida principalmente por los macrófagos activados, pero también por otros tipos celulares, como los linfocitos, los fibroblastos y los hepatocitos. ${ }^{212,213}$ El TNF $\alpha$ se sintetiza como un precursor transmembrana integrado (mTNF $\alpha$ ), que posteriormente es proteolíticamente clivado y liberado en forma soluble (sTNF $\alpha){ }^{214}$ Esta citoquina ejerce sus funciones celulares mediante la interacción con dos receptores de membrana, el TNFR1 (del inglés, Tumor Necrosis Factor Receptor) (también llamado p55) y el TNFR2 (también llamado p75). ${ }^{214}$ Son moléculas monoméricas que se encuentran en la superficie celular, pero que también pueden ser secretados en forma soluble (sTNFR) tras la unión con el TNF ${ }^{215}$ La unión de éste con cualquier TNFR de la superficie celular le confiere la actividad biológica. Por tanto, estos receptores median en la proliferación, en la supervivencia, en la diferenciación y en la apoptosis celular, pero es el propio TNF $\alpha$ el que parece jugar un papel, único y fundamental, en la regulación de la elección entre las vías de señalización pro- y antiapoptóticas y en el control de la proliferación y de la inflamación celular. $^{216,217}$ Ambos receptores son expresados simultáneamente en casi todos los tipos 
celulares, de modo que al unirse el mTNF $\alpha$ activa a ambos, pero el sTNF $\alpha$ estimula predominantemente al TNFR1, teniendo capacidades de señalización limitadas para el TNFR2. ${ }^{217}$

En el sistema nervioso central, los daños isquémicos y excitotóxicos aumentan la producción de esta citoquina, ${ }^{218}$ mientras que en el ojo, como ya se ha mencionado, se han detectado niveles elevados de $\mathrm{TNF} \alpha$ en las uveítis, en algunas degeneraciones retinianas hereditarias, en el glaucoma y en la VRP. 10,53-61 Sin embargo, sigue sin estar claro si su acción es beneficiosa o perjudicial para las neuronas retinianas. Se está empezando a pensar que el tipo de tejido y el ambiente celular son parámetros importantes para determinar el efecto que tendrá el TNF $\alpha{ }^{217}$ Así, se ha mostrado que el EPR es resistente a la muerte celular inducida por el TNF $\alpha,{ }^{219}$ por ello, el papel que pueda jugar en la retina patológica sigue siendo ambiguo, ya que podría ejercer una actividad proliferante y a la vez apoptótica, en enfermedades que cursan con la formación de membranas proliferativas, como la VRP asociada con el DR regmatógeno o la vitreorretinopatía diabética proliferante. ${ }^{220}$

En cuanto a sus receptores, no se expresan en condiciones normales en la retina, pero sí se detectan tras un daño, expresándose tanto el TNFR1 como el TNFR2 en las extensiones de las células de Müller, ${ }^{62}$ pudiendo así actuar esta citoquina sobre dichas células. No obstante, no se puede descartar que otras neuronas retinianas posean receptores para el $\mathrm{TNF} \alpha{ }^{62}$ aunque el papel que esta citoquina pueda ejercer sobre ellas no está claro. Clásicamente se ha involucrado al TNFR1 en la supresión de la inflamación; 221 mientras que el TNFR2, que es el principal receptor de las células mononucleares ${ }^{222}$ y del que se han encontrado concentraciones elevadas en el vítreo de pacientes con VRP, ${ }^{194}$ mediaría fundamentalmente la acción proapoptótica del $\mathrm{TNF}^{223}$ y prolongaría el efecto de esta citoquina al impedir su desnaturalización espontánea. ${ }^{224}$ Sin embargo, actualmente aún existen grandes controversias acerca de la función que llevan a cabo cada uno de los receptores del TNF $\alpha$, atribuyendo 
efectos neuroprotectores y/o neurodegenerativos a ambos. Así, estudios in vitro han mostrado que el TNF $\alpha$ ejerce un efecto apoptótico sobre las neuronas retinianas a través de su receptor TNFR1 tras isquemia, ${ }^{225}$ pero otros trabajos han demostrado neuroprotección mediada por este receptor tras axotomía, ${ }^{226}$ o incluso a través del TNFR2 tras isquemia. ${ }^{62} \mathrm{~A}$ su vez, el TNFR1 puede mediar en la apoptosis y en la supervivencia celular al ser inducido por el TNF $\alpha$, ya que la trimerización de este receptor en respuesta a dicha citoquina puede originarse a través de diferentes complejos. ${ }^{227}$ Sin embargo, a pesar de los diferentes mecanismos de acción que se pueden desencadenar tras la interacción del TNF $\alpha$ con sus receptores, se desconocen cuales son los predominantes en la patogenia de la VRP.

\subsubsection{Otras citoquinas secretadas por los macrófagos e}

\section{implicadas en el desarrollo de la vitreorretinopatía proliferante}

\section{TGF $\beta$ :}

El TGF $\beta$ es una citoquina con comportamiento dual, y su efecto final depende fundamentalmente de tres factores, del tipo celular sobre el que actúa, ${ }^{228}$ del grado de diferenciación celular, ${ }^{229}$ y de la presencia de otras citoquinas. ${ }^{230}$ Se han detectado niveles elevados de TGF $\beta$ en el vítreo de pacientes con VRP, correlacionándolo con la presencia de fibrosis intraocular. ${ }^{231}$ Esta citoquina constituye un elemento clave en la cicatrización y en la fibrosis, contribuyendo al flujo y a la activación de células inflamatorias, a la transdiferenciación de células epiteliales hacia mesenquimales, a la quimiotaxis de los fibroblastos y a la subsiguiente elaboración de la matriz extracelular. ${ }^{232}$ Otra acción importante es la relacionada con la inflamación y la inmunidad específica. Así a nivel experimental se ha observado que el TGF $\beta$ aumenta la permeabilidad endotelial y la epitelial, 
inhibiendo a su vez, la expresión de las proteasas de los macrófagos, induciendo la producción de colágeno y de otras proteínas de la matriz extracelular, y probablemente contribuyendo a la diferenciación de las células epiteliales hacia miofibroblastos. El conjunto de estas acciones contribuye a limitar el daño agudo, para dar lugar al proceso de reparación tisular. ${ }^{228}$ En el tejido nervioso induce la hipertrofia de las células gliales y su proliferación, y modula la expresión de algunas citoquinas, de tal forma que contribuye al efecto antiinflamatorio que se observa en otros tejidos. Además, bloquea la acción de la microglia activada, constituyendo éste otro elemento más a favor de su acción antiinflamatoria. ${ }^{230}$

En mamíferos se han identificado 3 isoformas, el TGF $\beta 1$, el TGF $\beta 2$ y el TGF $\beta 3$, funcionando conjuntamente a través de una vía de señalización principal, constituida por las proteínas SMADs. A nivel del sistema nervioso tanto central como periférico, destaca la ubicuidad del TGF $\beta 2$ y del TGF $\beta 3$, mientras que el TGF $\beta 1$ está casi totalmente ausente en el tejido nervioso no lesionado, limitándose su presencia al tejido meníngeo, ${ }^{230}$ siendo liberado fundamentalmente tras el daño del tejido nervioso.

- TGFß1: es secretado fundamentalmente por las plaquetas y los macrófagos activados, aunque se ha demostrado que también es producido por muchos otros tipos celulares, entre ellos, las células del EPR, y actúa sobre la mayoría de estirpes celulares. ${ }^{230}$ Esta citoquina se ha implicado en la patogenia de la $\mathrm{VRP}^{5,}, 9$ participando en la promoción de la contracción celular por parte del vítreo, ${ }^{233}$ y originando un aumento en la expresión del PDGF. ${ }^{234}$

- TGFß2: es sintetizado por varios tipos celulares, hallándose en numerosos tejidos, entre ellos el humor acuoso, la lágrima y el vítreo. ${ }^{235}$ Juega un papel muy importante en la cicatrización de heridas, inhibe la proliferación celular e induce varios efectos inmunosupresores, como la alteración de la producción del IFN $\gamma$ o de la actividad inflamatoria de los macrófagos. ${ }^{235} \mathrm{Su}$ papel en la VRP se conoce desde hace varios años, se ha encontrado en concentraciones 
elevadas en vítreos de pacientes con VRP, siendo ésta la isoforma predominante, ${ }^{236}$ e incluso su concentración se ha relacionado con la gravedad de la VRP. ${ }^{237}$

- $\underline{\text { TGF} \beta 3}$ : es sintetizado por varios tipos celulares, y se ha implicado en la diferenciación celular, en la embriogénesis y en el desarrollo, regulando la adhesión celular, la formación de la matriz extracelular y los procesos de cicatrización. ${ }^{238}$

\section{PDGF:}

El PDGF es secretado mayoritariamente por las plaquetas que llegan al interior del globo ocular tras la rotura de las barreras hemato-oculares. Esta citoquina es un factor quimiotáctico para los monocitos, los macrófagos y los polimorfonucleares neutrófilos del torrente sanguíneo; $;^{5,41}$ tiene una marcada acción quimiotáctica y mitogénica sobre las células mesenquimales y las gliales; induce la migración de las células del EPR; ${ }^{206}$ y estimula la síntesis y el depósito de colágeno. ${ }^{41}$ También es secretada por los macrófagos activados, estimulando aún más la quimiotaxis y la proliferación de los fibroblastos, de las células del EPR y de la glia, e induciendo la producción de colágeno. ${ }^{2,41}$

Sus efectos son mediados por los PDGFRs (del inglés, PDGF-Receptors) y la PI3K (del inglés, PhosphatidylInositol 3 Kinase), de modo que al inhibir ambas proteínas se reduce la producción de colágeno, la proliferación de los fibroblastos y los cambios asociados con la VRP, tanto en modelos in vivo como in vitro. ${ }^{233}$ Los niveles de PDGF se mantienen constantes durante todo el proceso de la VRP, ${ }^{239}$ implicándose en la contracción de las membranas retinianas. ${ }^{233,240,241}$ 


\section{IL1 $\alpha$ e IL1 $\beta$ :}

Estas IL son sintetizadas por una gran cantidad de células, incluyendo los macrófagos activados y los fibroblastos. Entre sus funciones se encuentran la activación de los leucocitos, de los monocitos y de las células endoteliales, el incremento de la migración de las células del EPR, y ser potentes mediadores de la inflamación. ${ }^{44}$ Se han detectado niveles elevados en el fluido subretiniano de pacientes con VRP, correlacionándose con el grado de severidad de esta patología, ${ }^{242}$ y en membranas de la VRP. ${ }^{61}$

\section{MIF:}

El MIF (del inglés, Macrophage migration Inhibitory Factor) es secretado por monocitos y macrófagos, siendo uno de sus principales estímulos la presencia de TNF $\alpha$. Sus funciones son inhibir la migración macrofágica, inducir la secreción de TNF $\alpha$ y actuar sinérgicamente con el IFN $\gamma$ en la inducción de la liberación de óxido nítrico por parte de los macrófagos. ${ }^{243}$ Se han encontrado concentraciones elevadas en vítreos de pacientes con VRP. ${ }^{244}$

\subsection{Agentes biológicos bloqueantes del TNF}

Durante las últimas dos décadas se ha producido un rápido e importante progreso en la identificación de las vías celulares y moleculares asociadas con un importante número de patologías inflamatorias y/o autoinmunes. Esto ha conducido al desarrollo de agentes terapéuticos específicos, que tienen como diana a los mediadores biológicos asociados con estas enfermedades, destacando los agentes que inhiben la acción del TNF.245

Existen cinco agentes biológicos terapeúticos, que tienen como diana la biodisponibilidad del TNF, aprobados por la FDA (Food and Drug Administration, EE.UU.). 
Cuatro de ellos fueron aprobados originariamente para el tratamiento de la artritis reumatoide, el etanercept $\left(\right.$ Enbrel $^{\circledR}$ ) en 1998, el infliximab (Remicade ${ }^{\circledR}$ ) en 1999, el adalimumab (Humira ${ }^{\circledR}$ ) en 2002, ${ }^{245}$ y el golimumab (Simponi ${ }^{\circledR}$ ) en $2009 ;{ }^{246}$ siendo el quinto el certolizumab pegol $\left(\mathrm{Cimzia}^{\circledR}\right.$ ) aprobado en 2007 para el tratamiento de la enfermedad de Crohn. ${ }^{247}$ Tras las indicaciones originales, progresivamente se han ido aprobando para su utilización en otras patologías.

- El etanercept está aprobado para el tratamiento de la artritis reumatoide activa de moderada a severa, de la artritis reumatoide poliarticular juvenil, de la artritis psoriásica, de la espondilitis anquilosante, y de las placas psoriásicas crónicas de moderadas a severas. ${ }^{248}$

- El infliximab está aprobado para el tratamiento de la artritis reumatoide de moderada a severa, de la artritis psoriásica, de la espondilitis anquilosante, de la colitis ulcerativa de moderada a severa, y de la enfermedad de Crohn de moderada a severa. ${ }^{249}$

- El adalimumab está aprobado para el tratamiento de la artritis reumatoide de moderada a severa, de la artritis reumatoide poliarticular juvenil, de la artritis psoriásica, de la espondilitis anquilosante, de la psoriasis, y de la enfermedad de Crohn de moderada a severa. ${ }^{250}$

- El golimumab está aprobado para el tratamiento de la artritis reumatoide, de la artritis psoriásica, y de la espondilitis anquilosante. ${ }^{246}$

- El certolizumab pegol está aprobado para el tratamiento de la enfermedad de Crohn y de la artritis reumatoide..$^{247}$

Además de estas indicaciones reconocidas, se sigue investigando activamente la eficacia y la seguridad de estos agentes en otras enfermedades inflamatorias y autoinmunes crónicas, siendo un buen ejemplo su utilización oftalmológica en casos de uveítis y de 
enfermedades inflamatorias oculares, aunque todavía no han sido oficialmente aprobados por la FDA para estas indicaciones. ${ }^{220}$

Cabe mencionar que potencialmente la peor complicación del tratamiento con antiTNFs es el desarrollo de una tuberculosis diseminada, por ello antes de comenzar a utilizarlos, se hace necesario llevar a cabo las pruebas pertinentes para descartar la presencia de una tuberculosis latente focalizada, que pudiera reactivarse bajo la terapia con estos agentes biológicos. $^{71}$

\subsubsection{Características}

Los agentes biológicos terapeúticos bloqueantes del TNF se agrupan en tres tipos, los receptores solubles del TNF (etanercept), los anticuerpos monoclonales anti-TNF (infliximab, adalimumab y golimumab), y los fragmentos Fab de un anticuerpo monoclonal anti-TNF unidos a una fracción de polietilenglicol (certolizumab pegol). ${ }^{247,251} \mathrm{~A}$ pesar de que los cinco agentes se unen al TNF, hay diferencias en cuanto a su eficacia y seguridad clínica.247, 251-253 Los cuatro primeros portan la porción activadora del complemento Fc de la inmunoglobulina G1 humana (IgG1). Esta región Fc es un componente nativo en los anticuerpos monoclonales, mientras que para construir el etanercept, es fusionada genéticamente a la porción soluble del receptor TNFR2. Esta región se une a receptores Fc presentes en las células inmunes, como los monocitos, los macrófagos, los granulocitos, las células NK (del inglés, Natural Killer), las células B y las plaquetas. ${ }^{254}$ Por el contrario, el certolizumab pegol carece de esta región Fc, lo que minimiza los efectos mediados por ésta, como son la citotoxicidad dependiente del complemento y la mediada por anticuerpos celulares. ${ }^{247}$ 


\section{Etanercept (Enbrel $\left.{ }^{\circledR}\right):$}

El etanercept es una proteina de fusión dimérica de 150 kDa, consistente en la porción extracelular del ligando de unión del receptor TNFR2 humano, unido a la porción Fc de una IgG1 humana. Se puede unir al TNF $\alpha$ y al TNF $\beta$ (también llamado LTA; del inglés, LymphoToxin Alpha), actuando competitivamente para inhibir su unión a los TNFRs de la superficie celular, y volviéndolos biológicamente inactivos. ${ }^{245}$ Forma uniones menos estables que los anticuerpos monoclonales, mayoritariamente con el mTNF $\alpha .{ }^{71}$ En las enfermedades oculares, se ha encontrado que es menos efectivo que los anticuerpos monoclonales para el tratamiento de las uveítis, atribuyéndose este menor efecto a su relativamente inferior estabilidad de unión, ya que está limitada al mTNF $\alpha .^{255-258}$ Sin embargo, la experiencia clínica hasta la fecha sugiere que podría ser una buena opción para el tratamiento de niños y adultos jóvenes, en comparación con los otros agentes. Por otra parte, aunque en algunos casos se obtiene una buena respuesta en el tratamiento de las uveítis, paradójicamente, mediante la utilización sistémica puede empeorar la inflamación ocular en algunos pacientes. ${ }^{220}$

\section{Infliximab (Remicade ${ }^{\circledR}$ ):}

El infliximab es un anticuerpo monoclonal IgG1 quimérico de 149 kDa, que está compuesto por una región humana constante (75\%) y por una murina variable (25\%). Se une específicamente al TNF $\alpha$ humano con gran afinidad y neutraliza su actividad biológica mediante la inhibición de la unión a sus receptores. ${ }^{245}$ Forma uniones estables con el sTNF $\alpha$ y el $\mathrm{mTNF} \alpha,{ }^{71}$ y tiene la capacidad de lisar células productoras de $\mathrm{TNF} \alpha$ para neutralizar su actividad. ${ }^{259}$ Existen discrepancias sobre su capacidad para unirse al TNF $\beta .^{245,259}$ En cuanto a las enfermedades oculares, se ha encontrado que es efectivo en las uveítis recurrentes, reduciendo la inflamación en el $80 \%$ de los casos, ${ }^{255,256,260}$ y en el tratamiento de la enfermedad de Behçet. ${ }^{258,261-263}$ 


\section{Adalimumab (Humira ${ }^{\circledR}$ ):}

El adalimumab es un anticuerpo monoclonal IgG1 recombinante humano de $148 \mathrm{kDa}$, con sus dos regiones, constante y variable, de origen totalmente humano. Se une específicamente y con gran afinidad al TNF $\alpha$ humano, dando lugar a uniones estables tanto con la forma soluble como con la transmembrana, ${ }^{71}$ pero no neutraliza al TNF $\beta .{ }^{245}$ A nivel ocular es efectivo en las uveítis ${ }^{258,264}$ y en la enfermedad de Behçet. ${ }^{265}$

\section{Golimumab (Simponi $\left.{ }^{\circledR}\right)$ :}

El golimumab es un anticuerpo monoclonal IgG1 recombinante humano de $150 \mathrm{kDa}$, en el que ambas regiones, constante y variable, son de origen totalmente humano. Se une específicamente y con gran afinidad al TNF $\alpha$ humano, tanto con la forma soluble como con la transmembrana. ${ }^{246}$

\section{Certolizumab pegol $\left(\right.$ Cimzia $\left.^{\circledR}\right)$ :}

El certolizumab pegol es un fragmento Fab de un anticuerpo monoclonal anti-TNF humanizado, posteriormente unido con una fracción de $40 \mathrm{KDa}$ de polietilenglicol. Se une específicamente y neutraliza tanto al sTNF $\alpha$ como al mTNF $\alpha$ humanos, e inhibe la señalización mediante la unión a ambos receptores. ${ }^{247,266}$

\subsubsection{Utilización intraocular}

Durante los últimos años, a través de múltiples estudios experimentales y de ensayos clínicos, se ha comenzado a evaluar la utilidad de los agentes bloqueantes del TNF a nivel ocular. Sin embargo, todavía no se poseen unos resultados contrastados y fiables acerca de la vida media intraocular; de la toxicidad retiniana en humanos; de la eficacia en la inhibición de 
la inflamación ocular, comparada entre varios agentes antagonistas del TNF; ni de la concentración mínima, en inyección intravítrea o subcutánea, que permite inhibir de forma eficiente la inflamación ocular.

Las inyecciones intravítreas son un buen sustituto de la administración sistémica de fármacos cuya diana terapéutica es el ojo, por ello, durante los últimos años se han comenzado a llevar a cabo diversos estudios para evaluar la utilidad de estos agentes inyectados en el vítreo. Esta vía de administración podría tener menos efectos adversos y originar unos menores costes, en comparación con la vía sistémica. ${ }^{220}$

\section{Etanercept (Enbrel $\left.{ }^{\circledR}\right)$ :}

La utilización de etanercept intravítreo se ha llevado a cabo en estudios experimentales en conejo, evaluando su seguridad y farmacocinética, pudiendo detectarse en el tejido retiniano hasta ocho semanas tras la inyección, sin que aparecieran signos de daño retiniano, mediante el empleo de dosis de hasta 2,5 mg. $^{267,268}$

En cuanto a su utilización en seres humanos, se han publicado estudios en edema macular diabético resistente a otros tratamientos, no apreciando reacciones adversas a los tres meses de seguimiento, pero tampoco mejoría clínica. ${ }^{65}$

\section{Infliximab (Remicade ${ }^{\circledR}$ ):}

La aplicabilidad del infliximab intravítreo se ha evaluado en varios estudios experimentales en conejo, determinando que dosis por debajo de $2 \mathrm{mg} / 0,1 \mathrm{~mL}$ podrían ser seguras, al no detectarse modificaciones funcionales ni histológicas en los tejidos oculares, ${ }^{66}$, ${ }^{269}$ y manteniendo una vida media en el vítreo de seis días. ${ }^{270}$ Se ha descrito su utilización intravítrea en un modelo de neovascularización coroidea inducida por láser en ratas, observando que dosis por debajo de $40 \mu$ g reducen la angiogénesis y la expresión de 
glicosaminoglicanos, implicados en los procesos de neovascularización coroidea, sin embargo, dosis superiores parecen originar el efecto contrario. ${ }^{271}$

En seres humanos se ha utilizado en pacientes con degeneración macular asociada a la edad (DMAE) no respondedores al tratamiento con anti-VEGF (del inglés, Vascular Endothelial Growth Factor), apuntando hacia una posible asociación entre el TNF y la DMAE; ${ }^{272}$ en otro trabajo realizado en pacientes con neovascularización coroidea secundaria a DMAE no respondedores al tratamiento con anti-VEGF, no se apreció mejoría en la agudeza visual ni cambios en el grosor macular central a los noventa días de seguimiento, desarrollándose en la mitad de los casos una inflamación ocular con gran aumento de la presión intraocular; ${ }^{67}$ en pacientes con uveítis no infecciosa crónica acompañada de una significativa pérdida visual y de edema macular central, se consiguió mejorar, aparentemente, la agudeza visual y reducir el grosor macular central a las cuatro semanas de la inyección; ${ }^{68}$ y en pacientes con edema macular diabético persistente, no se apreció mejoría en ninguno de los casos, detectando, en pacientes a los que se les aplicó una dosis alta, el desarrollo de una inflamación intraocular severa. $^{69}$

\section{Adalimumab (Humira ${ }^{\circledR}$ ):}

Los estudios experimentales con adalimumab intravítreo en conejo, se han centrado en determinar la posible toxicidad retiniana, revelando que dosis por debajo de $0,5 \mathrm{mg} / 0,1 \mathrm{~mL}$ no originan cambios morfológicos ni funcionales a los catorce días de seguimiento. ${ }^{273,274}$ Sin embargo, un estudio ha descrito el desarrollo de una reacción inflamatoria con necrosis retiniana al utilizar dosis superiores a $1 \mathrm{mg} / 0,1 \mathrm{~mL},{ }^{273}$ mientras que otro estudio similar, no reveló cambios a nivel retiniano con dosis de $5 \mathrm{mg} / 0,1 \mathrm{~mL} .^{274}$

En seres humanos, se ha utilizado en pacientes con uveítis controlada y edema macular quístico no respondedores al tratamiento con esteroides, no demostrando eficacia en la 
mejora de la agudeza visual ni cambios en el grosor de la retina central, pero tampoco se observaron efectos adversos a nivel sistémico u ocular; ${ }^{70}$ también se ha utilizado en pacientes con edema macular diabético persistente, y aunque no se apreció mejoría en ninguno de los casos, tampoco se detectaron efectos secundarios a nivel sistémico u ocular. ${ }^{69}$

\section{Golimumab (Simponi ${ }^{\circledR}$ ) y certolizumab pegol $\left(\right.$ Cimzia $\left.^{\circledR}\right)$ :}

No se han encontrado referencias sobre su utilización intravítrea. 
5. Material y métada 



\subsection{Experimentos}

\section{Puesta a punto y estandarización del cultivo organotípico de}

\section{neurorretina porcina:}

Con estos experimentos se pretendió poner a punto y estandarizar el método de cultivo de los explantes retinianos, evaluando los cambios espontáneos que sufren las células gliales retinianas, principalmente las células de Müller, durante el transcurso del cultivo. Para ello, se utilizaron 36 explantes de retina, procedentes de 6 ojos de cerdo. Los tiempos de estudio fueron $3(\mathrm{n}=12), 6(\mathrm{n}=12)$ y $9(\mathrm{n}=12)$ días de cultivo.

\section{Cultivo con PBMCs:}

Para estudiar las modificaciones que los PBMCs (del inglés, Peripheral Blood Mononuclear Cells) de sangre porcina, principalmente monocitos y linfocitos, inducen en las células gliales retinianas durante el cultivo. Se utilizaron 78 explantes retinianos, procedentes de 13 ojos. De ellos, 39 se cultivaron con PBMCs añadidos sobre los explantes retinianos en el día 0. Los tiempos de estudio fueron $3(n=13), 6(n=13)$ y $9(n=13)$ días. Los otros 39 explantes, cultivados sin PBMCs, fueron utilizados como controles de este experimento, con la misma distribución por tiempo de estudio.

\section{Cultivo con monocitos CD14+:}

Se pretendió identificar las modificaciones que los monocitos CD14+ ${ }^{+}$obtenidos a partir de sangre periférica y potencialmente productores de $\mathrm{TNF} \alpha,{ }^{275}$ inducen sobre las células gliales retinianas durante el cultivo. Se utilizaron 36 explantes retinianos, procedentes de 6 ojos. De ellos, 18 se cultivaron con monocitos $\mathrm{CD}_{14}{ }^{+}$añadidos al medio de cultivo en el día 0. Los tiempos de estudio fueron $3(n=6), 6(n=6)$ y $9(n=6)$ días. Los otros 18 explantes, 


\section{Material y métada}

cultivados sin monocitos $\mathrm{CD}_{14}{ }^{+}$, se utilizaron como controles de este experimento, con la misma distribución por tiempo de estudio.

\section{Cultivo con TNF $\alpha$ :}

Para determinar el posible efecto de esta citoquina proinflamatoria, y su concentración eficaz para inducir un aumento de la gliosis retiniana, se utilizaron 18 explantes, procedentes de 3 ojos, que fueron cultivados durante dos días con $25(n=3), 50(n=3), 100(n=3), 200(n=3)$ y $400 \mathrm{pg} / \mathrm{ml}(\mathrm{n}=3)$ de TNF $\alpha$ (recombinant porcine tumor necrosis factor alpha (E. Coliderived), aprox. ED50 18-30 pg/mL; R\&D Systems, Minneapolis, MN), añadido al medio de cultivo en el día 0 . La elección de las concentraciones de TNF $\alpha$ se basó en la información obtenida de estudios publicados, ${ }^{276,277}$ en los que se describen los niveles de TNF $\alpha$ producido por monocitos humanos, obtenidos de personas sanas y enfermas. Se utilizaron como controles 3 explantes cultivados durante 2 días sin TNF $\alpha$.

Para estudiar si la adición externa de $\mathrm{TNF} \alpha$ induce unas modificaciones retinianas constantes durante un periodo de cultivo más largo, se utilizaron 60 explantes retinianos, procedentes de 10 ojos. De los cuales 30 fueron cultivados con 100 pg/ml de TNF $\alpha$ añadido al medio de cultivo en el día 0 . Los tiempos de estudio fueron $3(n=10), 6(n=10)$ y $9(n=10)$ días. Los otros 30 explantes, cultivados $\sin \mathrm{TNF} \alpha$, se utilizaron como controles.

\section{Cultivo con adalimumab:}

Para evaluar las modificaciones que el adalimumab (Humira ${ }^{\circledR} 40 \mathrm{mg} / 0.8 \mathrm{ml}$; Abbott Laboratories Ltd., Queenborough, UK) induce sobre las células gliales retinianas, se utilizaron 36 explantes, procedentes de 6 ojos. De ellos 18 fueron cultivados con $10 \mu \mathrm{g} / \mathrm{ml}$ de adalimumab añadido al medio de cultivo en el día 0. La concentración de adalimumab se basó en la información de estudios previos, ${ }^{278,279}$ en los que se describen las dosis de agentes 
bloqueantes del TNF en cultivos celulares. Los tiempos de estudio fueron $3(n=6), 6(n=6)$ y 9 (n=6) días. Los otros 18 explantes, cultivados sin adalimumab, se utilizaron como controles de este experimento, con la misma distribución por tiempo de estudio.

\section{Cultivo con TNF $\alpha /$ adalimumab:}

Se pretendió evaluar la capacidad del adalimumab para reducir las modificaciones originadas por el TNF $\alpha$ en las células gliales retinianas. Para ello se utilizaron 60 explantes retinianos, procedentes de 10 ojos de cerdo. De ellos, 30 se cultivaron con 100 pg/ml de TNF $\alpha$ y $10 \mu \mathrm{g} / \mathrm{ml}$ de adalimumab, añadidos consecutivamente al medio en el día 0. Los tiempos de estudio fueron $3(n=10), 6(n=10)$ y $9(n=10)$ días. Los otros 30 explantes, cultivados con 100 pg/ml de TNF $\alpha$ y sin adalimumab, se utilizaron como controles, con la misma distribución por tiempo de estudio.

\subsection{Preparación y cultivo organotípico de los explantes de}

\section{neurorretina porcina}

Se utilizaron 54 globos oculares de cerdo procedentes del matadero Justino Gutiérrez S.L. (Laguna de Duero, Valladolid, España), de animales entre 6 y 8 meses de edad, recogidos en medio DMEM (Dulbecco's Modified Eagle Medium; Gibco ${ }^{\circledR}$, Paysley, Reino Unido), suplementado con $1 \%$ de antibióticos/antimicóticos $\left(\right.$ Gibco $\left.^{\circledR}\right)$, que fueron transportados refrigerados hasta el laboratorio. Allí se llevo a cabo el protocolo de preparación de los explantes de neurorretina, entre 30 minutos y 2 horas tras la enucleación del globo ocular, bajo condiciones asépticas en campana de flujo laminar (HERAsafe; Heraeus, Hanau, Alemania). 


\section{Material y métada}

\section{Protocolo:}

1. Se lavó cada globo ocular en etanol al 70\% durante 2 minutos (Fig. 5.2.1A).

2. Posteriormente se efectuó un lavado de cada ojo en DMEM limpio, 3 pases de 2 minutos cada uno (Fig. 5.2.1A).

3. Luego se colocó el globo ocular en una placa de cultivo con medio DMEM, y se retiraron los restos de tejidos extraoculares mediante unas tijeras de disección (Fig. 5.2.1B\&C).

4. Se incidió la esclera con una aguja estéril de 22G, a la altura de la ora serrata, para realizar un ojal por el que poder introducir unas tijeras corneales (Fig. 5.2.1D).

5. Se diseccionó el globo ocular, aproximadamente en el final del segmento anterior, del que se traccionó, arrastrando con él al vítreo; y en el segmento posterior, donde se mantuvo adherida la retina (Fig. 5.2.1E).

6. Se trasladó el polo posterior del globo ocular a una nueva placa con medio DMEM limpio y se desprendió mecanicamente la retina neural del EPR, con la ayuda de un pincel (Fig. 5.2.1F\&G)

7. Se seccionó la base del nervio óptico con unas tijeras corneales de Wescott, para completar el DR (Fig. 5.2.1H).

8. Se desenrolló la retina en la placa de cultivo, mediante unos pinceles (Fig. 5.2.1I), y se cortó en cuadrados de $5 \times 5 \mathrm{~mm}$, mediante unas tijeras de Vannas, tomando los explantes de la zona media de la retina, descartando las regiones más periféricas y la zona del nervio óptico, y evitando la presencia de vasos visibles y de bordes irregulares (Fig. 5.2.1J).

9. Se depositaron 1,6 mL de medio de cultivo en cada una de las seis cavidades de la placa, bajo los pocillos (Transwell ${ }^{\circledR} 0.4 \mu \mathrm{m}$ pore, $30 \mathrm{~mm}$; Corning Inc., New York, EE.UU.), de modo 
que el medio contactara con la membrana del pocillo, pero no la sobrepasara. Así, la retina se adhirió perfectamente a la membrana, evitando que flotara sobre el medio. Como medio de cultivo se utilizó Neurobasal A, suplementado con 10\% de FBS (del inglés, Fetal Bovine Serum; Gibco ${ }^{\circledR}$ ) o 2\% de FPS (del inglés, Fetal Porcine Serum; Gibco ${ }^{\circledR}$ ) inactivados por calor, 2\% de B-27 (Gibco ${ }^{\circledR}$ ), 1\% de L-Glutamina (Sigma-Aldrich ${ }^{\circledR}$, Saint Louis, MO, EE.UU.) y 1\% de antibióticos/antimicóticos, que fueron previamente atemperados a $37^{\circ} \mathrm{C}$ en un baño termostático (Raypa, España).

10.Se trasladó y depositó el explante retiniano, con ayuda de una espatulilla y un pincel, sobre la membrana de los pocillos, de modo que los fotorreceptores quedaran en contacto con ésta (Fig. 5.2.1K).

11.Se estiró la muestra con ayuda de un pincel, para que no quedara enrollado el explante y conseguir un contacto adecuado con la membrana (Fig. 5.2.1L).

12.Se cultivaron seis explantes de una misma neurorretina en cada placa, de modo que se tomaron muestras control y experimento en cada tiempo de estudio (Fig. 5.2.2).

13.Se introdujo la placa de cultivo con los explantes de neurorretina en un incubador (HERAcell; Heraeus) con una atmósfera enriquecida al $5 \%$ de $\mathrm{CO}_{2}$, en el que se mantuvieron a lo largo del cultivo.

14.Se comprobó el nivel del medio de cultivo tras 1 hora en el incubador.

15.Se recambió el medio al día siguiente de iniciado el cultivo, y posteriormente cada dos días hasta que finalizó el experimento, añadiendo siempre 1,5 mL de medio recién elaborado y atemperado. 


\section{Material y métado}

En total se cultivaron 324 explantes neurorretinianos que se mantuvieron en cultivo durante 2, 3, 6 o 9 días según el experimento. Paralelamente, también se obtuvieron muestras de retinas recién desprendidas, previamente al comienzo de los cultivos, y se procesaron, para evaluar el posible daño originado durante la disección y la manipulación del tejido.

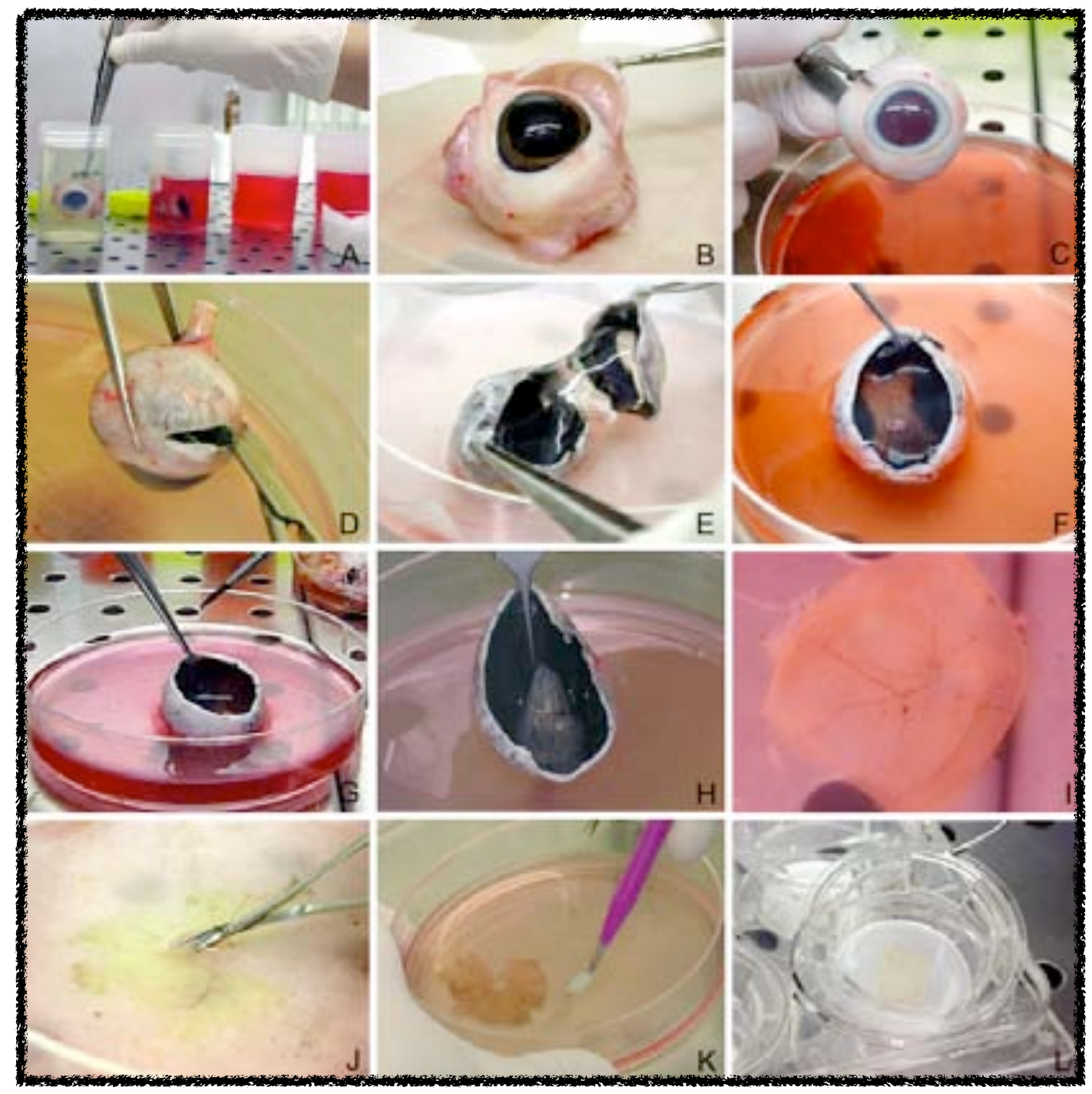

Figura 5.2.1 Obtención y preparación de los explantes de neurorretina porcina para su cultivo. 


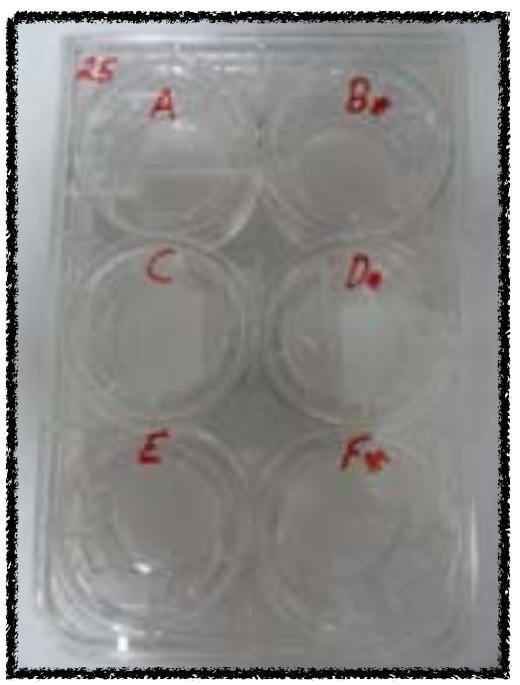

Figura 5.2.2 Placa donde se cultivaron explantes control $(A, C \& E)$ y experimento $\left(B^{*}\right.$, $\left.D^{*} \& F^{*}\right)$, de modo que se tomaron muestras pareadas a los $3\left(A \& B^{*}\right), 6\left(C \& D^{*}\right)$ y 9 $\left(E \& F^{\star}\right)$ días de cultivo.

\subsection{Extracción de los PBMCs y adición a los explantes en}

\section{cultivo}

Se utilizó sangre periférica porcina procedente del matadero Justino Gutiérrez S.L., de animales entre 6 y 8 meses de edad. Se recogieron 15 muestras de $50 \mathrm{~mL}$, anticoaguladas con 1\% de heparina (Heparina Leo, Byk Leo, España), en tubos cónicos (BD Falcon ${ }^{\mathrm{TM}}$; Becton \& Dickinson, Franklin Lakes, NJ, EE.UU.), y se transportaron refrigeradas hasta el laboratorio. Se comenzó el protocolo de extracción de los PBMCs 30 minutos tras su obtención, bajo condiciones asépticas en campana de flujo laminar.

\section{Protocolo (modificado de Boyum): ${ }^{280}$}

1. Se diluyó la sangre heparinizada con PBS (0,2 M pH 7,4; del inglés, Phosphate Buffered Saline; Invitrogen ${ }^{\circledR}$, Paysley, Reino Unido), en proporción 1:1, y se mezcló por inversión. 


\section{Material y métado}

2. Se pipeteó cuidadosamente la mezcla sangre-PBS sobre medio volumen de Histopaque ${ }^{\circledR}-1077$ (Sigma-Aldrich ${ }^{\circledR}$ ), para ello se utilizaron tubos de centrífuga cónicos de 15 mL (Fisherbrand; Fisher Scientific S.L., Madrid, España), evitando en lo posible que la sangre y el medio de separación se mezclaran.

3. Se centrifugó a 400g durante 30 minutos (Centrifuge 5702; Eppendorf, Hamburgo, Alemania), obteniéndose una interfase opaca en la que estaban presentes los PBMCs.

4. Se retiró el plasma, que estaba situado en la parte superior, y se recogieron los PBMCs. Debajo quedó el Histopaque ${ }^{\circledR}-1077$ y en el fondo los eritrocitos y los polimorfonucleares.

5. Se depositaron los PBMCs en otro tubo limpio y se mezclaron por inversión con $10 \mathrm{~mL}$ de PBS, para lavarlos mediante centrifugación a 250g durante 10 minutos.

6. Se retiró el sobrenadante, rico en plaquetas, quedando un precipitado en el fondo del tubo.

7. Se resuspendió el pellet con $30 \mathrm{~mL}$ de medio de cultivo retiniano y se evaluó el número de células presentes y su viabilidad, mediante tinción con Azul Tripán y contaje con hemocitómetro (Reichert-Jung, Buffalo, NY, EE.UU.).

\section{Cultivo de los PBMCs:}

Se realizaron extensiones celulares sobre porta de una gota de los PBMCs, para comprobar, mediante tinción de Giemsa, la presencia de monocitos en las muestras; y se realizaron cultivos en placa (Easy Grip Cell Culture Dish (Primaria surface treatment) 35x10mm; Becton \& Dickinson) de $1 \times 10^{6}$ células, utilizando el medio de cultivo retiniano, para comprobar la evolución de los monocitos-macrófagos en dicho medio. Transcurridos dos días, se fijaron y se tiñeron las células mediante Giemsa. 
Se añadieron $3 \times 10^{5}$ células, en un volumen de $20 \mu \mathrm{L}$, sobre cada explante de retina. Para asegurarse de que los PBMCs se mantuvieran sobre la retina durante el cultivo, se colocó un pequeño cilindro de plástico sobre los explantes, depositando dentro los PBMCs (Fig. $5.3 A \& B)$.

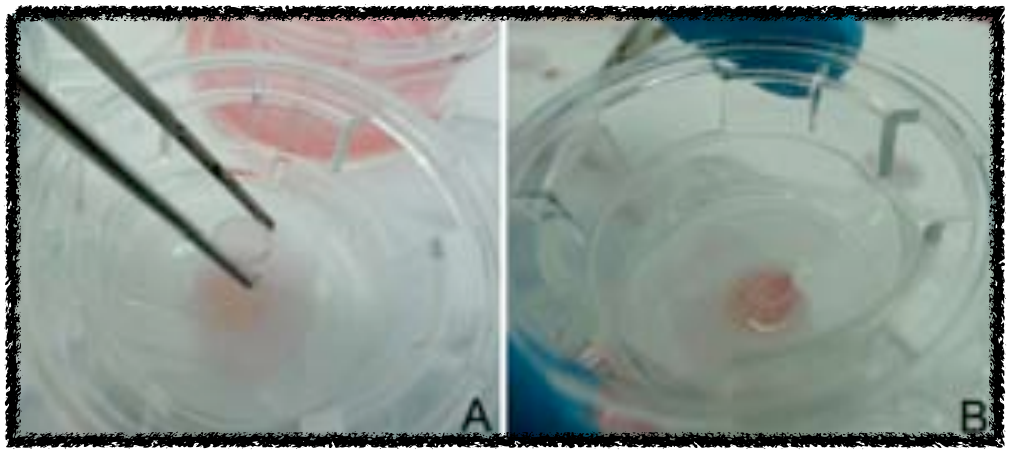

Figura 5.3 Colocación de un cilindro de plástico sobre un explante neurorretiniano (A) y posterior depósito de los PBMCs en su interior (B).

\subsection{Extracción de los monocitos $\mathrm{CD}_{14}{ }^{+}$y adición a los}

\section{explantes en cultivo}

Las técnicas de obtención y purificación de los monocitos $\mathrm{CD}_{14}{ }^{+}$se realizaron a partir de los protocolos proporcionados por el grupo de investigación liderado por el Dr. Javier Domínguez, del Instituto Nacional de Investigación y Tecnología Agraria y Alimentaria (INIA, Madrid, España).

\subsubsection{Obtención de los PBMCs}

Se recogieron, en el matadero Justino Gutiérrez S.L., 10 muestras de $50 \mathrm{ml}$ de sangre periférica porcina anticoagulada con 2\% de EDTA (del inglés EthyleneDiamineTetraacetic Acid; Fluka $^{\circledR}$ Analytical, Steinheim, Suecia) en tubos cónicos (BD Falcon ${ }^{\mathrm{TM}}$ ), y se transportaron 


\section{Material y métada}

refrigeradas hasta el laboratorio. Se comenzó el protocolo de extracción de los PBMCs 30 minutos tras su obtención, bajo condiciones asépticas en campana de flujo laminar.

\section{Protocolo (modificado de Gonzalez y cols.): ${ }^{281}$}

1. Se dividió el volumen de sangre en 2 tubos, con $25 \mathrm{~mL}$ cada uno, sobre los que se añadieron 6,5 mL de dextrano al 6\% (dextran from Leuconostoc spp; Fluka ${ }^{\circledR}$ Analytical), completando el volumen hasta $50 \mathrm{~mL}$ con PBS al 2\% de FBS.

2. Se agitó la mezcla y se dejó reposar 30 minutos, para que se produjera la sedimentación de los hematíes.

3. Se prepararon, en tubos de 15mL (Fisher Scientific S.L.), $1220 \mu \mathrm{L}$ de Percoll $^{\circledR}$ 9:1 en HBSS (Hank's Balanced Salt Solution; Gibco ${ }^{\circledR}$ ) con $780 \mu \mathrm{L}$ de medio RPMI (Roswell Park Memorial Institute medium; Gibco ${ }^{\circledR}$ ) suplementado con 5\% de FBS, 5\% de Hepes (Sigma-Aldrich ${ }^{\circledR}$ ), 2\% de L-Glutamina y 2,5\% de EDTA (para utilizarlo en el paso 8).

4. Tras la sedimentación de las muestras, se trasladó la parte superior, consituida por los monocitos, los linfocitos, los polimorfonucleares y los posibles restos de hematíes, a tubos nuevos de $50 \mathrm{~mL}$, y se completó el volumen hasta $50 \mathrm{~mL}$ con PBS al 2\% de FBS.

5. Se centrifugó a 1400 rpm durante 15 minutos.

6. Se retiró el sobrenadante, quedando un pellet en el fondo del tubo.

7. Se añadieron $2 \mathrm{~mL}$ de RPMI sobre el pellet, y se resuspendieron las células.

8. Se depositaron éstas sobre los $2 \mathrm{~mL}$ de la mezcla de Percoll ${ }^{\circledR}$ 9:1 y de RPMI, preparados previamente en el paso 3. Evitando en lo posible que las células resuspendidas y el medio de separación se mezclaran. 
9. Se centrifugó a $1600 \mathrm{rpm}$ durante 15 minutos a 25ํㅡ y sin freno, para no distorsionar la fase. En el fondo aparecieron los polimorfonucleares y los posibles eritrocitos; en la porción superior el Percoll ${ }^{\circledR}$; en la interfase los PBMCs (linfocitos y monocitos); y sobre éstos el RPMI.

10.Se recogió la interfase y se lavó, resuspendiendo en $1 \mathrm{~mL}$ de PBS al 2\% de FBS, y posteriormente completando el volumen hasta $10 \mathrm{~mL}$.

11.Se centrifugó a 1000 rpm durante 10 minutos a $4^{\circ} \mathrm{C}$.

12.Se lisaron los posibles restos de hematíes mediante choque osmótico, resuspendiendo las células en $9 \mathrm{~mL}$ de agua destilada durante 28 segundos. Se paró la reacción de lisis con $3 \mathrm{~mL}$ de NaCl (PANREAC Química S.A.U., Barcelona, España) al 3,5\% en PB (0,1 M, pH 7’4; del inglés Phosphate Buffer). Finalmente se añadió PBS al 2\% de FBS hasta $50 \mathrm{~mL}$ y se centrifugó a 1000 rpm durante 8 minutos a 4ํㅡ․

13.Se lavaron las células en PBS al 2\% de FBS, centifugando posteriormente a $1000 \mathrm{rpm}$ durante 8 minutos a $4^{\circ} \mathrm{C}$ (Fig. 5.4.1).

14.Se resuspendieron las células en $30 \mathrm{~mL}$ de PBS al 2\% de FBS y se contaron mediante hemocitómetro, previa tinción con Azul Tripán.

15.Se estudió, mediante citometría de flujo, la pureza de la fracción celular obtenida. 


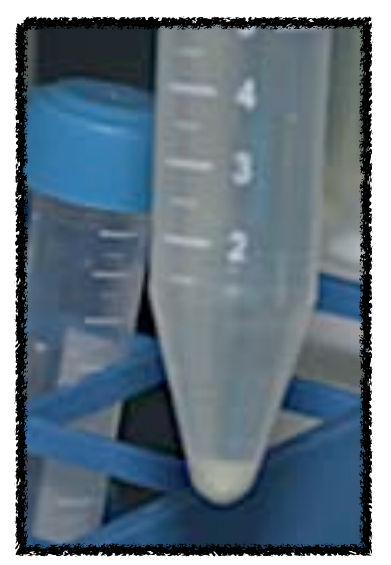

Fig. 5.4.1 Pellet de PBMCs.

\subsubsection{Deplección y selección celular magnética}

Tras la obtención de los PBMCs, se procedió a realizar una selección magnética en columna mediante una unidad de separación QuadroMACS ${ }^{\mathrm{M}}$ (Miltenyi Biotec, Gladbach, Alemania), utilizando columnas de separación del tipo LS (Miltenyi Biotec).

\section{Depleción celular magnética:}

Mediante esta técnica se buscó separar la población monocítica de la linfocítica, utilizando anticuerpos frente a las proteínas CD3, CD8a y CD45RA, presentes en la superficie de los linfocitos.

\section{Protocolo:}

1. Se resuspendieron los PBMCs (aprox. $20 \times 10^{6}$ células) en $2 \mathrm{~mL}$ de buffer de separación. Éste estaba compuesto por PBS suplementado con 5\% de FBS y 2\% de EDTA.

2. Se incubaron los anticuerpos primarios anti-CD3 (1:200, monoclonal mouse anti-human CD3 IgG1; Sigma-Aldrich $\left.{ }^{\circledR}\right)$, anti-CD8a (1:100, monoclonal mouse anti-pig wCD8a IgG2a; AbD Serotec, Oxford, Reino Unido) y anti-CD45RA (1:100 monoclonal mouse anti-pig CD45RA IgG1; AbD Serotec) durante 90 minutos. 
3. Se añadieron $2 \mathrm{~mL}$ de buffer de separación y se centrifugó a 1000 rpm durante 8 minutos.

4. Se resuspendieron las células en $100 \mu \mathrm{L}$ de buffer de separación y se incubaron con microbeads magnéticas (1:25, goat anti-mouse IgG microbeads; Miltenyi Biotec), durante 20 minutos.

5. Se añadieron 2 mL de buffer de separación y se centrifugó a 1000 rpm durante 8 minutos.

6. Se resuspendieron las células en $500 \mu \mathrm{L}$ de buffer de separación.

7. Se colocaron las columnas de separación en la unidad de separación, y se hidrataron haciendo correr $3 \mathrm{~mL}$ de buffer de separación a través de éstas.

8. Se depositaron en las columnas los $500 \mu \mathrm{L}$ de buffer de separación con las células.

9. Se dejó correr y se recolectaron las células no unidas a los anticuerpos (monocitos).

10.Se lavaron las columnas con buffer de separación (3 x $3 \mathrm{~mL})$, y se continuaron recogiendo las células no unidas (monocitos).

11.Se retiraron las columnas de la unidad de separación, y se depositaron $5 \mathrm{~mL}$ de buffer de separación.

12.Se dejó correr y se recolectaron en un tubo limpio las células unidas a los anticuerpos (linfocitos).

13.Se realizó el recuento celular de la fracción monocítica obtenida, mediante hemocitómetro tras tinción con Azul Tripán.

14.Se estudió, mediante citometría de flujo, la pureza de las fracciones celulares obtenidas. 


\section{Material y método}

\section{Selección celular magnética:}

Mediante esta técnica se buscó separar la población monocítica CD14+ del resto de la población celular presente, utilizando un anticuerpo frente a la proteína CD14, presente en la superficie celular de un determinada población de monocitos. ${ }^{275}$

\section{Protocolo:}

1. Se resuspendió la fracción celular (aprox. $12 \times 10^{6}$ células), que no se unió a los anticuerpos durante la deplección negativa, en $100 \mu \mathrm{L}$ de buffer de separación.

2. Se incubó el anticuerpo primario anti-CD14 (1:4, monoclonal mouse anti-human CD14 microbeads; Miltenyi Biotec) durante 15 minutos a $4^{\circ} \mathrm{C}$.

3. Se añadieron $2 \mathrm{~mL}$ de buffer de separación y se centrifugó a 1000 rpm durante 8 minutos.

4. Se resuspendieron las células en $500 \mu \mathrm{L}$ de buffer de separación.

5. Se colocaron las columnas de separación en la unidad de separación, y se hidrataron haciendo correr $3 \mathrm{~mL}$ de buffer de separación a través de éstas.

6. Se depositaron en las columnas los $500 \mu \mathrm{L}$ de buffer de separación con las células.

7. Se dejó correr y se recolectaron las células no unidas al anticuerpo (linfocitos y monocitos CD14).

8. Se lavaron las columnas con buffer de separación (3 x $3 \mathrm{~mL}$ ) y se continuaron recogiendo las células no unidas (linfocitos y monocitos CD14).

9. Se retiraron las columnas de la unidad de separación y se depositaron $5 \mathrm{~mL}$ de buffer de separación. 
10.Se dejó correr y se recolectaron en un tubo limpio las células unidas al anticuerpo (monocitos CD14+).

11.Se realizó el recuento celular de la fracción monocítica obtenida, mediante hemocitómetro tras tinción con Azul Tripán.

12.Se estudió, mediante citometría de flujo, la pureza de las fracciones celulares obtenidas.

\subsubsection{Citometría de flujo}

Para estudiar cada una de las fracciones celulares obtenidas previamente, se resuspendieron las células en PBS y se pasaron las muestras por un citómetro de flujo (Cytomics FC 500 Cytometer; Beckman-Coulter, Fullerton, CA, EE.UU.). El número de eventos evaluados fue superior a 20.000 en cada muestra. Los datos fueron recogidos y analizados mediante el software Cytomics RXP (Beckman-Coulter), evaluando las proporciones celulares mediante un histograma tamaño/complejidad.

\subsubsection{Cultivo de los monocitos $\mathrm{CD}^{+} 4^{+}$}

Se realizaron cultivos en placa (Easy Grip Cell Culture Dish (Primaria surface treatment) $35 \times 10 \mathrm{~mm}$ ) de $1 \times 10^{6}$ monocitos $\mathrm{CD} 14^{+}$, utilizando medio de cultivo retiniano, para comprobar la evolución de los monocitos-macrófagos en dicho medio, transcurridos cuatro días se fijaron las células y se tiñeron mediante Giemsa o se marcaron con anticuerpos frente a CD172a/SWC3 y a CD203a/SWC9. Se añadieron $1 \times 10^{6}$ células al medio de cultivo retiniano. 


\subsubsection{Determinación de los niveles de TNF $\alpha$ en el medio}

\section{de cultivo}

A partir de los sobrenadantes de los cultivos control y con monocitos CD $14^{+}$, recogidos al recambiar el medio en los días 1, 3, 5, 7 y 9 de cultivo, y de medio Neurobasal A suplementado, se determinaron los niveles de TNF $\alpha$. Para ello, se utilizaron kits comerciales de ELISA (Enzyme-Linked ImmunoSorbent Assay) tipo sandwich cuantitativo, estando los pocillos tapizados con un anticuerpo monoclonal específico para TNF $\alpha$ porcino (Porcine TNFa/TNFSF1A Immunoassay, Quantiquine ${ }^{\circledR} ;$ R\&D Systems, Abingdon, Reino Unido), con estos kits la concentración mínima detectable es de 3,7 pg/mL.

\section{Protocolo:}

1. Se depositaron $50 \mu \mathrm{L}$ del diluyente de ensayo (proporcionado en el kit de ELISA) y $50 \mu \mathrm{L}$ del sobrenadante en cada uno de los pocillos de la placa del ELISA, y se incubó durante 2 horas.

2. Se lavó cada pocillo 5 veces utilizando $400 \mu \mathrm{L}$ de la solución de lavado (proporcionada en el kit del ELISA).

3. Se depositaron $100 \mu \mathrm{L}$ del conjugado porcino (proporcionado en el kit del ELISA) en cada pocillo y se incubó durante 2 horas.

4. Se lavó cada pocillo 5 veces utilizando $400 \mu \mathrm{L}$ de la solución de lavado.

5. Se depositaron $100 \mu \mathrm{L}$ de la solución sustrato (proporcionada en el kit del ELISA) en cada pocillo y se incubó 30 minutos, protegiendo de la luz.

6. Se depositaron $100 \mu \mathrm{L}$ de la solución de parada (proporcionada en el kit del ELISA) en cada pocillo. 
7. Se determinó la densidad óptica en cada pocillo en los 30 minutos posteriores, mediante un lector Spectra Max M5 (Molecular Devices, Sunnyvale, EE.UU.), utilizando una longitud de onda de $450 \mathrm{~nm}$, con una corrección de onda de $540 \mathrm{~nm}$.

Con las lecturas obtenidas se realizó una curva para determinar los niveles de producción de citoquinas en base a la dilución de los controles del kit del ELISA, diluidos en una serie $1: 2(1.500,750,375,187,5,93,8,46,9$ y $23,4 \mathrm{pg} / \mathrm{mL})$. Como control positivo se utilizó el proporcionado en el kit del ELISA.

\subsection{Procesamientos}

Se procesaron muestras retinianas de 2, 3, 6 y 9 días de cultivo, así como muestras tomadas antes de comenzar los cultivos.

\section{Crioprocesamiento:}

1. Se fijaron las muestras, durante un máximo de 2 horas, en paraformaldehido (PF; PANREAC Química S.A.U.) al 4\% en PB.

2. Se lavaron las muestras en PB y se crioprotegieron en concentraciones crecientes de sacarosa (PANREAC Química S.A.U.) en PB.

$15 \% 1$ hora $\rightarrow 20 \% 1$ hora $\rightarrow 30 \% 12$ horas

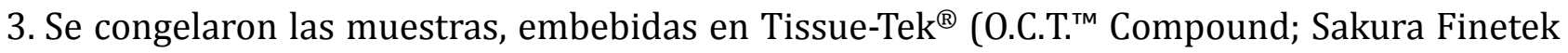
Europe B.V., Alphen, Holanda), mediante nieve carbónica.

4. Se conservaron las muestras en ultracongelador a $-80^{\circ} \mathrm{C}$ (HERAfreeze; Heraeus), hasta que se cortaron en criostato (CM 1900; Leica, Nussloch, Alemania). 


\section{Material y método}

5. Se recogieron cortes de 5 o $12 \mu$ m en portaobjetos comerciales (SuperFrost ${ }^{\circledR}$ Plus; MenzelGläser, Braunschweig, Alemania) y se conservaron en ultracongelador hasta su utilización.

\section{Inclusión en epoxi-resina (araldita):}

1. Se fijaron las muestras, durante un máximo de 2 horas, en PF al 4\% en PB.

2. Se lavaron las muestras en PB y se realizó una deshidratación en alcoholes crecientes:

Etanol (Sigma-Aldrich ${ }^{\circledR}$ ) 50\% 10 minutos $\rightarrow$ Etanol 75\% 10 minutos $\rightarrow$ Etanol 90\% 10 minutos $\rightarrow$ Etanol 96\% 10 minutos $\rightarrow$ 2x Etanol 100\% 10 minutos $\rightarrow$ Óxido de Propileno (Sigma-Aldrich ${ }^{\circledR}$ ) 10 minutos

3. Se realizó la impregnación en epoxi-resina (araldita; TAAB, Berks, Reino Unido):

Óxido de Propileno/Araldita (3/1) 1 hora $\rightarrow$ Óxido de Propileno/Araldita (1/1) 1 hora $\rightarrow$ Óxido de Propileno/Araldita (1/3) 12 horas $\rightarrow$ Araldita 60ํ 30 minutos

4. Se incluyeron las muestras en moldes y se dejó polimerizar la resina a $60^{\circ} \mathrm{C}$ durante 24 horas.

5. Se cortaron las muestras con ultramicrotomo (Ultratome III 8800; LKB, Bromma, Suecia) y se recogieron en portaobjetos tratados con (3-Aminopropyl)triethoxy-silane (Sigma$\left.\operatorname{Aldrich}^{\circledR}\right)$. 


\subsection{Técnicas de tinción histológica y citológica}

\section{Hematoxilina-Eosina:}

1. Se dejaron descongelar los cortes de las neurorretinas durante 5 minutos.

2. Se lavaron en PB durante 30 minutos, para eliminar los restos de Tissue-Tek ${ }^{\circledR}$.

3. Se tiñeron con hematoxilina (Sigma-Aldrich ${ }^{\circledR}$ ) 5 minutos.

4. Se lavaron en agua durante 5 minutos.

5. Se deshidrataron en etanol al $80 \%$ durante 2 minutos.

6. Se tiñeron con eosina (Sigma-Aldrich ${ }^{\circledR}$ ) durante 5 minutos.

7. Se deshidrataron en alcoholes de graduación creciente:

$2 \times$ Etanol 96ㅇ 2 minutos $\rightarrow 2 \times$ Etanol 100 2 minutos

8. Se aclararon en xilol (Sigma-Aldrich $\left.{ }^{\circledR}\right)(3 \times 5$ minutos $)$.

9. Se montaron con Entellan ${ }^{\circledR}$ (Merck, Darmstadt, Alemania).

\section{Azul de Toluidina:}

1. Se tiñeron los cortes incluidos en epoxi-resina con una gota de Azul de Toluidina (solución 1\%; PANREAC Química S.A.U.) durante 5 minutos a $60^{\circ} \mathrm{C}$.

2. Se lavaron en agua, en agua destilada y se dejaron secar a $60^{\circ} \mathrm{C}$.

3. Se montaron con Entellan ${ }^{\circledR}$. 


\section{Tinción de Giemsa:}

1. Se fijaron las extensiones celulares o las células cultivadas en placa con PF al $4 \%$ en PB durante 5 minutos.

2. Se lavaron varias veces en PB.

3. Se refijaron con metanol al 5\% (PANREAC Química S.A.U.) durante 5 minutos.

4. Se lavaron en PB.

5. Se tiñeron las células con solución de Giemsa (Sigma-Aldrich ${ }^{\circledR}$ ) al 20\% en PBS durante 1 hora.

6. Se lavaron las muestras en PB.

7. Se diferenció con solución de ácido acético (Sigma-Aldrich ${ }^{\circledR}$ ) al 0,1\% en agua destilada.

8. Se deshidrataron con pases rápidos en alcoholes de graduación creciente:

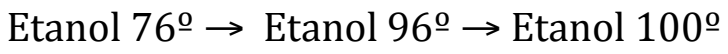

9. Se aclararon con xilol.

10.Se montaron con Entellan ${ }^{\circledR}$.

\section{Azul Tripán:}

1. Sobre un cubreobjetos se depositaron $20 \mu \mathrm{L}$ de Azul Tripán (Sigma-Aldrich ${ }^{\circledR}$ ).

2. Sobre el colorante se pipetearon $20 \mu \mathrm{L}$ de la solución celular.

3. Se mezclaron bien y se depositaron sobre un hemocitómetro. 


\subsection{Técnicas de inmunohistoquímica e inmunocitoquímica}

\subsubsection{Estudio de las células de Müller}

Se evaluó la proteina GFAP, presente en los filamentos intermedios de las células gliales (astrocitos y células de Müller) e implicada en los procesos de gliosis reactiva; ${ }^{25,282-284}$ y la proteina CRALBP (del inglés, Cellular RetinALdehide-Binding Protein), presente en el citoplasma de las células de Müller e implicada en el metabolismo de la vitamina A.285, 286 Realizando dobles marcajes para ambas proteínas se pueden diferenciar las células de Müller $\left(\mathrm{GFAP}^{+}\right.$y $\left.\mathrm{CRALBP}^{+}\right)$de los astrocitos $\left(\mathrm{GFAP}^{+} \text {y CRALBP }\right)^{-286,287}$

\section{Protocolo para cortes crioprocesados:}

1. Se descongelaron las muestras durante 5 minutos.

2. Se lavaron en PB durante 30 minutos, para eliminar los restos de Tissue-Tek ${ }^{\circledR}$.

3. Se lavaron los cortes en TBS (0,2 M, pH 7,6; del inglés Tris Buffered Saline; Gibco ${ }^{\circledR} 5$ minutos.

4. Se secaron los portas, se introdujeron en una cámara húmeda, y se enmarcaron los cortes con Pap Pen (Liquid Bloquer Super Pap Pen; Daido Sangyo Co. Ltd., Tokio, Japón).

5. Se incubó el anticuerpo primario anti-GFAP (1:200, polyclonal rabbit anti-cow Glial Fibrilary Acidic Protein; DakoCytomation Inc., Carpinteria, CA, EE.UU.) durante 30 minutos.

6. Se lavaron los cortes en TBS ( 3 x 5 minutos).

7. Se incubó el anticuerpo primario anti-CRALBP (1:1000, monoclonal mouse anti-human Cellular Retinaldehyde-Binding Protein; Abcam plc., Cambridge, UK), durante 12 horas a $4^{\circ}{ }^{\circ} \mathrm{C}$.

8. Se lavaron los cortes en TBS ( 3 x 5 minutos). 


\section{Material y métada}

9. Se incubaron los anticuerpos secundarios (1:200, Alexa Fluor ${ }^{\circledR} 568$ o 594 (rojo) goat antirabbit IgG, y Alexa Fluor ${ }^{\circledR} 488$ (verde) goat anti-mouse IgG; Molecular Probes ${ }^{\mathrm{TM}}$, Eugene, EE.UU.) durante 1 hora en oscuridad.

10.Se lavaron los cortes en TBS (3 x 5 minutos).

11.Se tiñeron con DAPI $(10 \mu \mathrm{g} / \mathrm{mL}$; del inglés, 4',6-diamino-2-phenilindole dihydrochloride; Molecular Probes ${ }^{\mathrm{TM}}$ ) durante 8 minutos en oscuridad.

12.Se lavaron los cortes en TBS (3 x 5 minutos).

13.Se montaron utilizando un medio específico para muestras de inmunofluorescencia, fluorescent mounting medium (DakoCytomation Inc.).

\section{Protocolo para cortes incluidos en epoxi-resina (araldita):}

1. Se lavaron las muestras en óxido de propileno durante 30 minutos.

2. Se desplastificaron en solución envejecida de etóxido sódico durante 1 hora. Compuesta por 50\% de etóxido sódico envejecido, 30\% de acetona y 20\% de tolueno.

3. Se lavaron los cortes en acetonas de graduación decreciente para hidratarlos:

Acetona 100\% 10 minutos $\rightarrow$ Acetona $90 \% 10$ minutos $\rightarrow$ Acetona 76\% 10 minutos $\rightarrow$ Acetona $50 \% 10$ minutos

4. Se lavaron en TBS durante 10 minutos.

5. Se secaron los portas, se introdujeron en una cámara húmeda, y se enmarcaron los cortes con Pap Pen.

6. Se incubó el anticuerpo primario anti-GFAP durante 30 minutos.

7. Se lavaron los cortes en TBS ( 3 x 5 minutos). 
8. Se incubó el anticuerpo secundario (1:200, Alexa Fluor ${ }^{\circledR} 594$ (rojo); Molecular Probes ${ }^{\mathrm{TM}}$ ), durante 1 hora en oscuridad.

9. Se lavaron los cortes en TBS ( 3 x 5 minutos).

10.Se tiñeron con DAPI durante 8 minutos en oscuridad.

11.Se lavaron los cortes en TBS ( 3 x 5 minutos).

12.Se montaron con fluorescent mounting medium.

\subsubsection{Estudio de los monocitos y de los macrófagos}

\section{Células en placa de cultivo:}

Se evaluó la proteina CD172a/SWC3, presente en la línea monocitaria porcina, y la CD203a/SWC9, presente en los macrófagos maduros. ${ }^{288,289}$ Realizando dobles marcajes se permite diferenciar ambas poblaciones celulares.

\section{Protocolo:}

1. Se retiró el medio de cultivo y se fijaron las células con PF al 4\% en PB durante 5 minutos.

2. Se lavaron en PBS ( $3 \times 5$ minutos).

3. Se incubó en suero de cabra (Sigma-Aldrich ${ }^{\circledR}$ ) al 5\% en PBS durante 20minutos.

4. Se incubó el anticuerpo primario CD203a/SWC9 (1:100, monoclonal mouse anti-pig CD203a; AbD Serotec) durante 12 horas a $4^{\circ} \mathrm{C}$.

5. Se lavaron en PBS ( 3 x 5 minutos). 


\section{Material y métado}

6. Se incubó el anticuerpo secundario (1:200, Alexa Fluor ${ }^{\circledR} 594$ (rojo) goat anti-rabbit IgG; Molecular Probes ${ }^{\mathrm{TM}}$ ) durante 1 hora en oscuridad.

7. Se lavaron en PBS ( $3 \times 5$ minutos).

8. Se incubó el anticuerpo primario CD172a/SWC3 (1:10, monoclonal mouse anti-pig CD172a:FITC (verde); AbD Serotec) durante 12 horas a $4^{\circ}$ y en oscuridad.

9. Se lavaron en PBS ( 3 x 5 minutos).

10.Se tiñeron con DAPI durante 8 minutos en oscuridad.

11.Se lavaron en PBS (3 x 5 minutos).

12.Se montaron con fluorescent mounting medium.

\subsection{Evaluación microscópica}

Las preparaciones fueron evaluadas mediante un microscopio de luz transmitida Leica DM4000B (Leica Microsystems, Wetzlar, Alemania), equipado con lámpara de epifluorescencia. Las imágenes fueron capturadas con una cámara Leica DFC490 (Leica Microsystems). Las preparaciones procesadas para su estudio mediante microscopía confocal fueron evaluadas con un sistema de imágen para microscopía confocal Leica TCS SP2 (Leica Microsystems) equipado con láseres $\mathrm{Ar}-\mathrm{Kr}$, estos estudios fueron llevados a cabo en la Universidad de Alicante (Alicante, España), con la colaboración del Profesor Nicolás Cuenca. 
Los estudios comparativos basados en la expresión de los marcadores inmunofluorescentes se llevaron a cabo en imágenes adquiridas con los mismos niveles de exposición, intensidad y ganancia. El brillo y el contraste de las imágenes fue ajustado mediante el software Adobe Photoshop (versión 10.0.1 para Macintosh; Adobe Systems, San Jose, EE.UU.).

Todos los reactivos utilizados en este trabajo fueron atemperados previamente a su utilización.

Todos los protocolos en los que no se indica la temperatura fueron llevados a cabo a la temperatura ambiente del laboratorio.

En los casos que fue requerido, el $\mathrm{pH}$ fue ajustado mediante un pHmetro (pH-Meter BASIC 20+; Crison Instruments S.A., Barcelona, España), añadiendo $\mathrm{HCl}$ o $\mathrm{NaOH}$ (ambos PANREAC Química S.A.U.) según fue necesario.

Las medidas del espesor retiniano se realizaron con el software ImageJ (version 1.4.1o, para Macintosh; National Institute of Health, EE.UU).

Todos los anticuerpos primarios utilizados en este trabajo han sido previamente descritos en otros estudios y su especificidad celular está bien caracterizada, por éste y otros grupos de investigación. Complementaria y paralelamente a los experimentos se procesaron muestras control, en las que se omitió el anticuerpo primario, no encontrando inmunoreactividad en ningún caso. 

6. Resultados 



\subsection{Caracterización histológica e inmunohistoquímica de la retina porcina recién desprendida}

\section{Evaluación histológica de la retina recién desprendida:}

A partir de las muestras retinianas recién desprendidas, procesadas y teñidas con Azul de Toluidina, se observó que a pesar del desprendimiento mecánico al que fueron sometidas las muestras para su separación del EPR, se conservó perfectamente la compleja arquitectura retiniana, permitiendo diferenciar las nueve capas de la retina neural (Fig. 6.1.A). Los segmentos externos (OS; del inglés Outer Segments) e internos (IS; del inglés, Inner Segments) de los fotorreceptores se mantuvieron íntegros tras dicha maniobra. En lo que respecta a las capas nucleares, tanto la externa (ONL; del inglés, Outer Nuclear Layer) como la interna (INL; del inglés Inner Nuclear Layer) presentaron, aproximadamente, entre 5 y 6 filas de núcleos en estas muestras.

\section{Evaluación inmunohistoquímica de la retina recién desprendida:}

En estas muestras, la GFAP solo se detectó a nivel de la membrana limitante interna (ILM; del inglés Inner Limmiting Membrane) y en la capa de fibras del nervio óptico (NFL; del inglés, Nerve Fiber Layer) (Fig. 6.1.B). La otra proteína evaluada, CRALBP, se identificó a través de todo el espesor retiniano (Fig. 6.1.C). La tinción nuclear DAPI permitió identificar y evaluar la organización de la capa de las células ganglionares (GCL; del inglés, Ganglion Cell Layer), de la INL y de la ONL, presentando éstas un patrón de conservación adecuado tras el desprendimiento mecánico. 


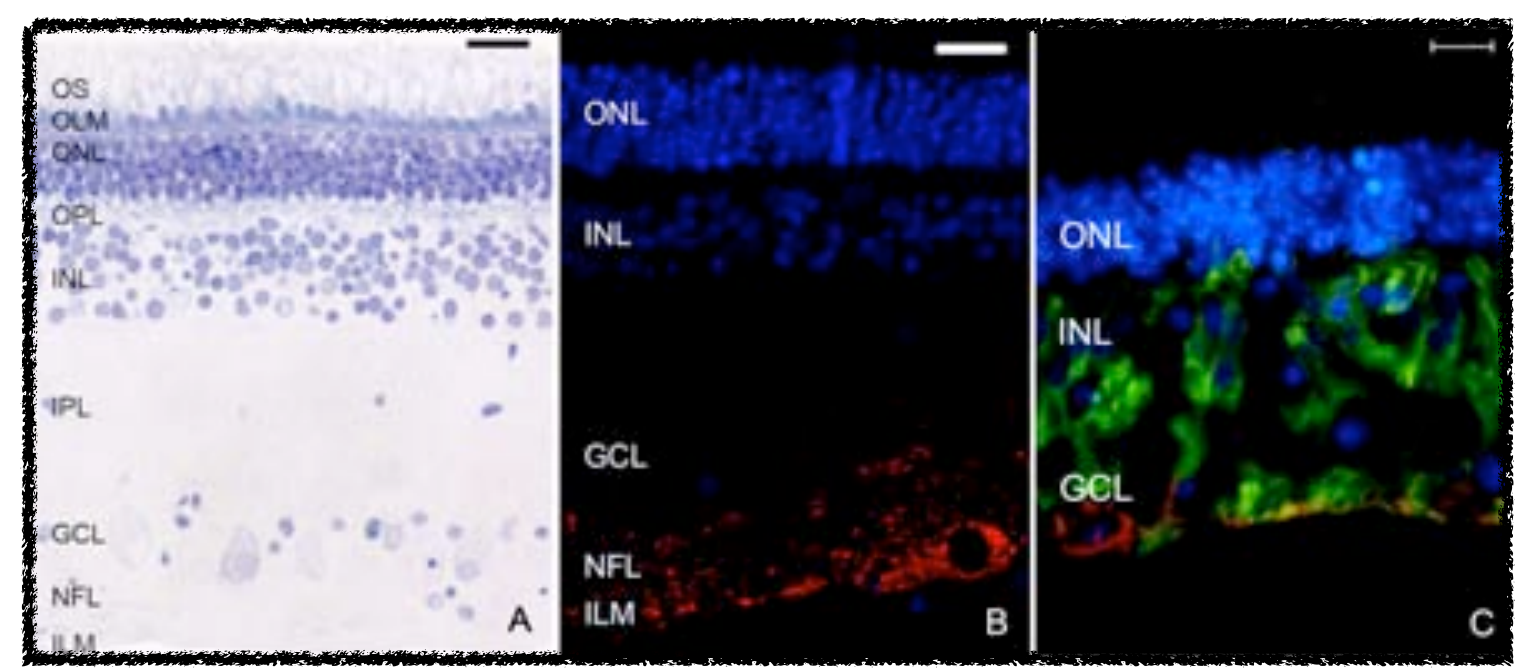

Figura 6.1 Tinción con Azul de Toluidina (A), y distribución de la GFAP (B\&C, rojo) y de la CRALBP $(C$, verde) en retinas porcinas recién desprendidas. Los núcleos celulares se muestran teñidos con DAPI (B\&C, azul). OS: segmentos externos de los fotorreceptores; OLM: membrana limitante externa; ONL: capa nuclear externa; OPL: capa plexiforme externa; INL: capa nuclear interna; IPL: capa plexiforme interna; GCL: capa de las células ganglionares; NFL: capa de fibras del nervio óptico; ILM: membrana limitante interna. Barras de escala: $20 \mu \mathrm{m}$.

\subsection{Caracterización histológica e inmunohistoquímica de}

\section{los explantes neurorretinianos durante el cultivo}

\section{Evaluación histológica de los explantes durante el cultivo:}

En los explantes cultivados y teñidos con Azul de Toluidina, a los tres días (Fig. 6.2.1A) los OS de los fotorreceptores aparecieron fragmentados y desorganizados, mientras que los IS, aún presentes, mostraron una morfología similar a la observada tras el desprendimiento mecánico. En este tiempo de estudio aún se mantuvieron entre 5 y 6 filas de núcleos de los fotorreceptores en la ONL, pero ya se pudo apreciar una pérdida de la compactación celular en esta capa. Aunque el resto de capas retinianas se mostraron aparentemente normales, comenzaron a detectarse algunos cambios histológicos. En la INL se observó una estructuración celular aparentemente normal, pero con procesos de vacuolización. En la capa 
plexiforme interna (IPL; del inglés, Inner Plexiform Layer) se apreciaron restos nucleares, mientras que en la GCL se observaron procesos de vacuolización.

Tras seis días en cultivo (Fig. 6.2.1B), al igual que a los tres días, se pudieron identificar restos celulares desprendidos de los OS de los fotorreceptores en lo que se correspondería con el área subretiniana (Figs. 6.2.1A\&B, áreas elipsoidales). En este tiempo de estudio dejaron de apreciarse, histológicamente, los IS, y se observó un notable acortamiento en la capa plexiforme externa (OPL; del inglés, Outer Plexiform Layer) y en la IPL. El número de líneas nucleares en la ONL se mantuvo aparentemente constante, mientras que en la INL apareció marcadamente reducido. Se percibieron núcleos celulares en la IPL, y desaparecieron, casi por completo, las células ganglionares de la GCL.

A los nueve días de cultivo se apreció una neoformación tisular (Fig. 6.2.1C flechas) en la zona más externa de la retina. Los OS de los fotorreceptores dejaron de apreciarse en el área subretiniana. La ONL mostró una marcada pérdida de la compactación y de la organización celular característica, observando un engrosamiento de esta capa. Mientras que la INL apareció profundamente desorganizada. No fue posible identificar la IPL y la OPL ya que estaban muy reducidas, y la mayoría de las células ganglionares habían desaparecido. 


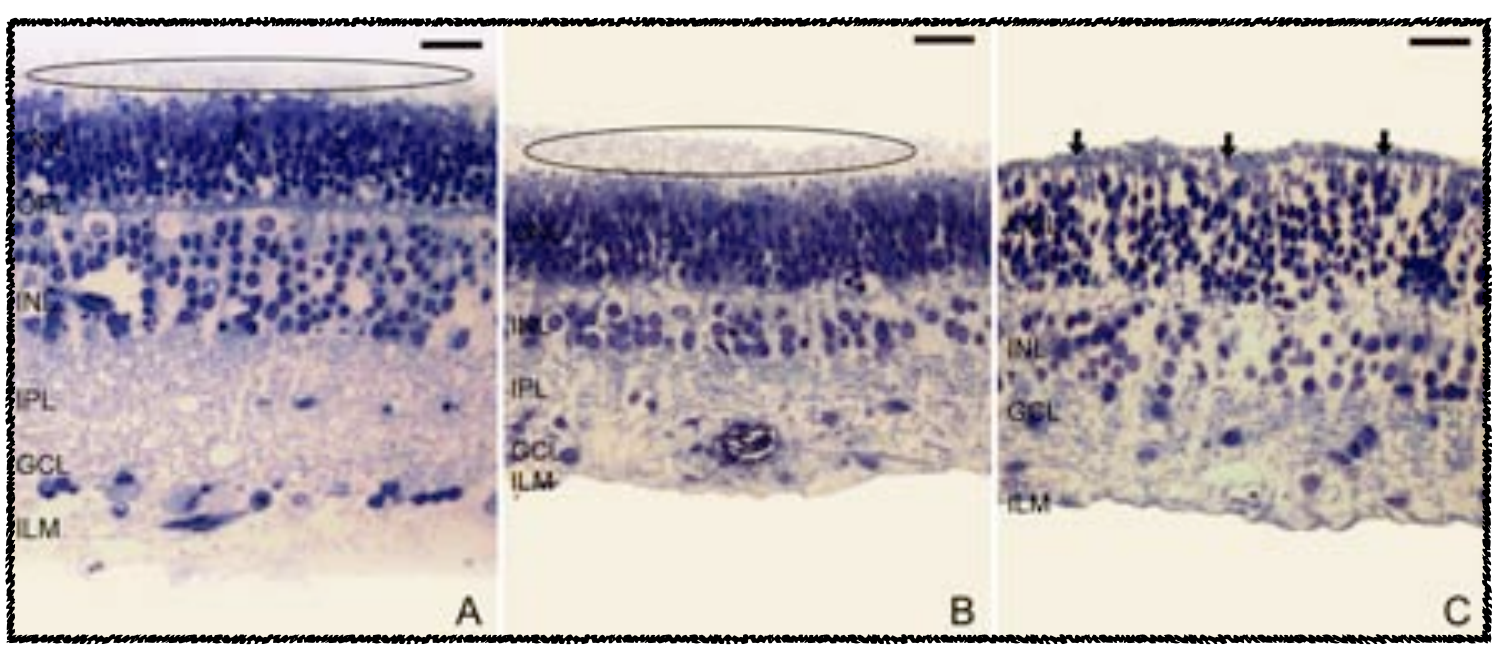

Figura 6.2.1 Tinción con Azul de Toluidina en explantes cultivados durante $3(A), 6(B)$ y 9 (C) días. ONL: capa nuclear externa; OPL: capa plexiforme externa; INL: capa nuclear interna; IPL: capa plexiforme interna; GCL: capa de las células ganglionares; ILM: membrana limitante interna. Barras de escala: $20 \mu \mathrm{m}$.

\section{Evaluación inmunohistoquímica de los explantes durante el cultivo:}

En las muestras inmunomarcadas con anticuerpo anti-GFAP (Fig. 6.2.2A-C) se pudo observar como, progresivamente y a lo largo del cultivo, fue aumentado la expresión de esta proteína en comparación con las muestras recién desprendidas (Fig. 6.1B). Por otra parte, se observó una desorganización progresiva de la estructura retiniana, apreciándose una mayor distancia entre los núcleos celulares, y perdiéndose, en algunas zonas, la clara diferenciación histológica de las capas retinianas.

A los tres días de cultivo (Fig. 6.2.2A) apareció una mayor expresión de la GFAP a nivel de la NFL, llegando incluso a presentarse en la GCL. Por otra parte, también comenzó a observarse como los filamentos intermedios $\mathrm{GFAP}^{+}$se prolongaban a lo largo del citoplasma de las células de Müller, atravesando el nivel de la INL y llegando incluso a adentrarse en la ONL.

Tras seis días en cultivo (Fig. 6.2.2B) la expresión de esta proteina aumentó considerablemente en las capas retinianas más internas, apreciándose completamente los 
cuerpos de las células de Müller a lo largo del tejido retiniano, debido a la notable expresión de la GFAP en su interior. Por otra parte, los filamentos intermedios $\mathrm{GFAP}^{+}$crecieron por las prolongaciones de las células de Müller en las capas más externas, apareciendo a través de la ONL, llegando a contactar con la OLM y comenzando a extenderse por esta estructura en algunos puntos (Fig. 6.2.2B flechas).

A la finalización del cultivo, es decir a los 9 días (Fig. 6.2.2C), se apreciaron perfectamente los cuerpos de las células de Müller, que discurren desde la ILM hasta la OLM, repletos de GFAP, al igual que sus múltiples prolongaciones celulares, que se extienden por el espesor retiniano rodeando a las células neuronales. En este punto, sus extensiones más externas marcadas con anticuerpo anti-GFAP atravesaron la OLM y comenzaron a invadir el área subretiniana, disponiéndose en una fina formación de monocapa perpendicularmente al tejido retiniano (Fig. 6.2.2C flechas). Por otra parte, en este tiempo de estudio, se redujo considerablemente el número de núcleos marcados con DAPI en la INL, no apreciándose éstos en la GCL.

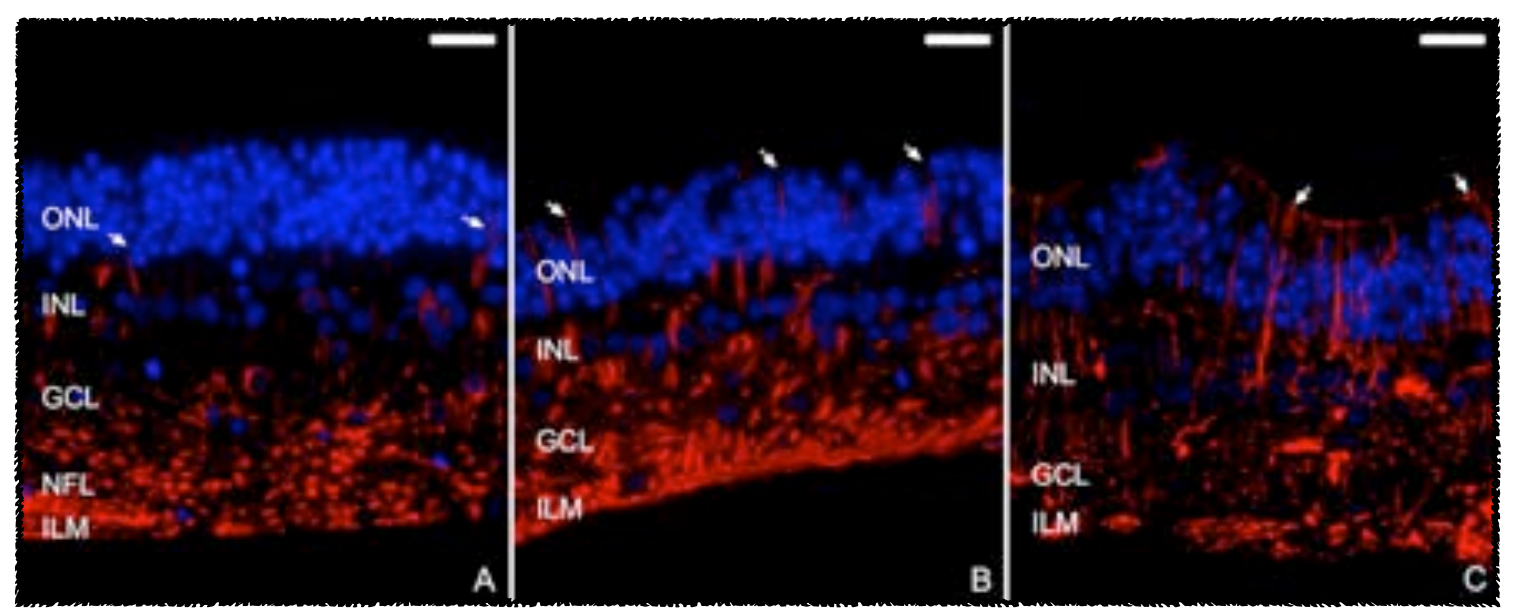

Figura 6.2.2 Distribución de la GFAP (rojo) en explantes cultivados durante $3(A), 6(B)$ y 9 (C) días. Los núcleos celulares se muestran teñidos con DAPI (azul). ONL: capa nuclear externa; INL: capa nuclear interna; GCL: capa de las células ganglionares; NFL: capa de fibras del nervio óptico; ILM: membrana limitante interna. Barras de escala: $20 \mu m$. 


\section{Resultados}

Los explantes doblemente inmunomarcados con anticuerpos anti-GFAP y anti-CRALBP (Fig. 6.2.3A-C) permitieron valorar subjetivamente la cantidad de células de Müller que expresaron GFAP, del total CRALBP presentes en el espesor retiniano. De este modo, comparado con las células de Müller $\mathrm{CRALBP}^{+}$, solo un pequeño número de células presentaron reactividad $\mathrm{GFAP}^{+}$, extendiéndose el marcaje a lo largo de éstas, progresivamente durante el cultivo, y finalmente, alcanzando las capas retinianas más externas, llegando hasta la OLM. Se apreció una perdida de la compactación nuclear, claramente marcada a nivel de la ONL, observando como las prolongaciones $\mathrm{GFAP}^{+}$de las células de Müller discurren entre los cuerpos celulares de los fotorreceptores (Fig. 6.2.3C flechas).

La expresión de la CRALBP se mantuvo aparentemente constante a lo largo del cultivo (Fig. 6.2.3A-C). Por otra parte, los dobles inmunomarcajes con los anticuerpos mencionados, permitieron diferenciar a las células de Müller $\left(\mathrm{GFAP}^{+} \mathrm{CRALBP}^{+}\right)$de los astrocitos $\left(\mathrm{GFAP}^{+}\right.$ CRALBP-), apreciándose como aumentó notablemente la expresión de la GFAP en las capas más internas de la retina, correspondiéndose en gran parte con astrocitos (Fig. 6.2.3A-C).

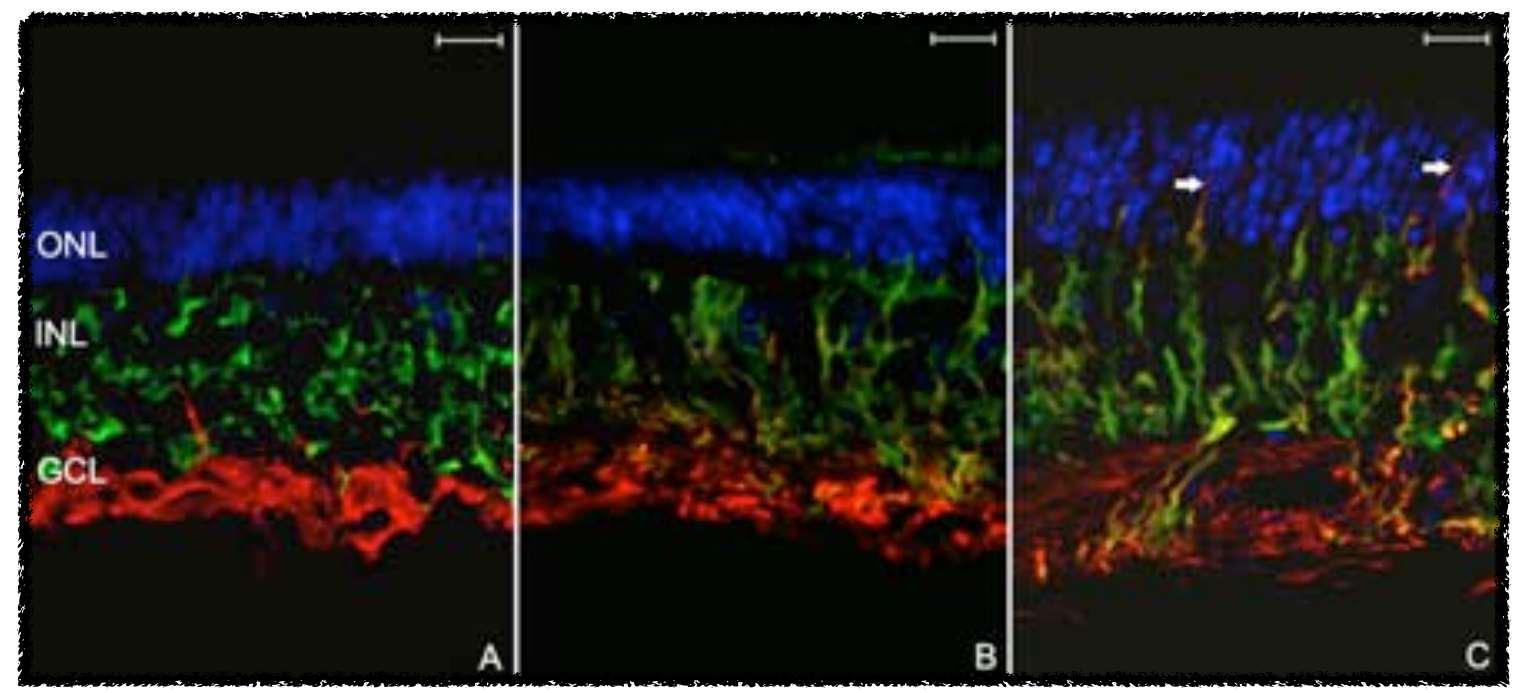

Figura 6.2.3 Distribución de la GFAP (rojo) y de la CRALBP (verde) en explantes cultivados durante $3(A), 6(B)$ y $9(C)$ días. Los núcleos celulares se muestran teñidos con DAPI (azul). ONL: capa nuclear externa; INL: capa nuclear interna; GCL: capa de las células ganglionares. Barras de escala: $20 \mu \mathrm{m}$. 
Los explantes doblemente inmunomarcados y evaluados mediante microscopía confocal, revelaron que la proteína CRALBP se presentó más concentrada en las capas retinianas externas. A los seis días de cultivo (Fig. 6.2.4A) solo algunas células de Müller expresaron GFAP en sus prolongaciones más externas (Fig. 6.2.4A flechas), en comparación con el total de células CRALBP ${ }^{+}$. En este punto, los cuerpos celulares de los astrocitos y sus prolongaciones se mantuvieron localizadas en la NFL (Fig. 6.2.4A asteriscos). A los nueve días (Fig. 6.2.4B) la GFAP fue expresada por un mayor número de células de Müller, llegando a atravesar la OLM (Fig. 6.2.4B flechas) y comenzando a apreciarse en el área subretiniana, mientras que los astrocitos mantuvieron su cuerpo celular en la NFL, pero orientando sus prolongaciones hacia capas externas (Fig. 6.2.4B asterisco).

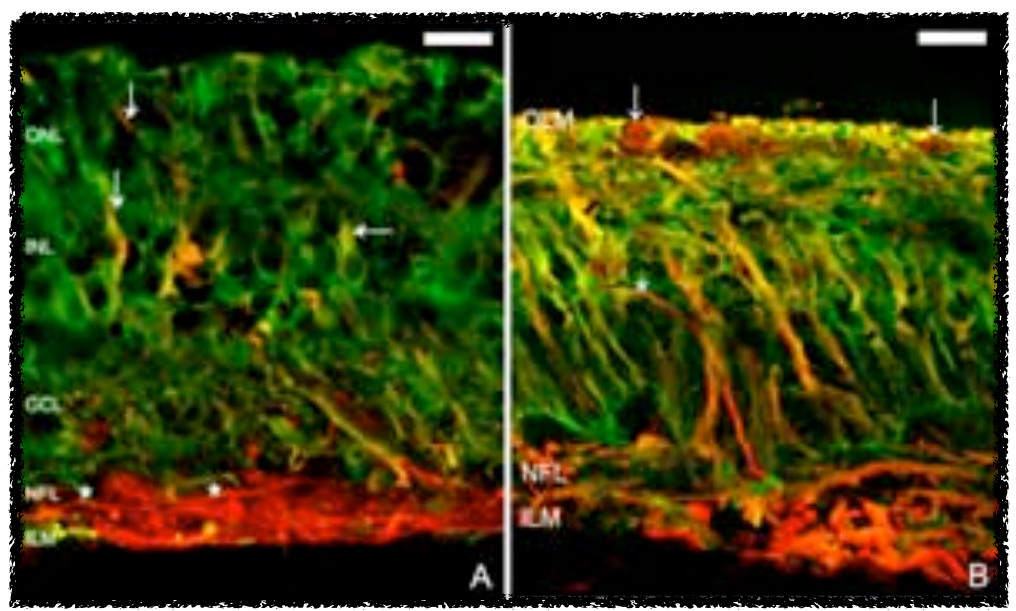

Figura 6.2.4 Distribución de la GFAP (rojo) y de la CRALBP (verde), evaluadas mediante microscopía confocal, en explantes cultivados durante $6(A)$ y 9 (B) días. OLM: membrana limitante externa; ONL: capa nuclear externa; INL: capa nuclear interna; GCL: capa de las células ganglionares. NFL: capa de fibras del nervio óptico; ILM: membrana limitante interna. Barras de escala: $20 \mu \mathrm{m}$. 


\section{Resultados}

\section{Otros hallazgos:}

Durante el desarrollo de los cultivos organotípicos, se percibió macroscópicamente como los explantes retinianos mantuvieron su transparencia y fueron adelgazándose durante el cultivo. Este adelgazamiento originó la visualización de pequeños vasos, que no habían sido perceptibles al comienzo del cultivo. Los explantes que perdieron la transparencia en los primeros días de cultivo fueron descartados del estudio.

Por otra parte, durante las primeras fases de la puesta a punto del modelo de cultivo organotípico de neurorretina porcina, se pudo apreciar como algunos explantes presentaron a los nueve días de cultivo un patrón de desorganización celular más pronunciado, perdiéndose completamente la arquitectura retiniana. Estos hallazgos solo aparecieron en los primeros experimentos.

En estas muestras más degeneradas, teñidas con Azul de Toluidina (Fig. 6.2.5A), se observó como el pequeño número de núcleos celulares presentes a los nueve días de cultivo, aparecieron degenerados y distribuidos aleatoriamente por el parénquima retiniano, sin ningún patrón de organización. Por otra parte, en la región externa a la OLM apareció una gruesa capa de tejido neoformado, orientada perpendicularmente al resto del parénquima retiniano (Fig. 6.2.5A flechas). Las muestras inmunomarcadas con anti-GFAP (Fig. 6.2.5B) corroboraron que, los pocos núcleos $\mathrm{DAPI}^{+}$presentes aparecían distribuidos al azar, mientras que la expresión de la GFAP aparecía aumentada a nivel de la NFL. Varias prolongaciones $\mathrm{GFAP}^{+}$de las células de Müller se extendían externamente a la OLM (Fig. 6.2.5B flechas), con una orientación perpendicular. 


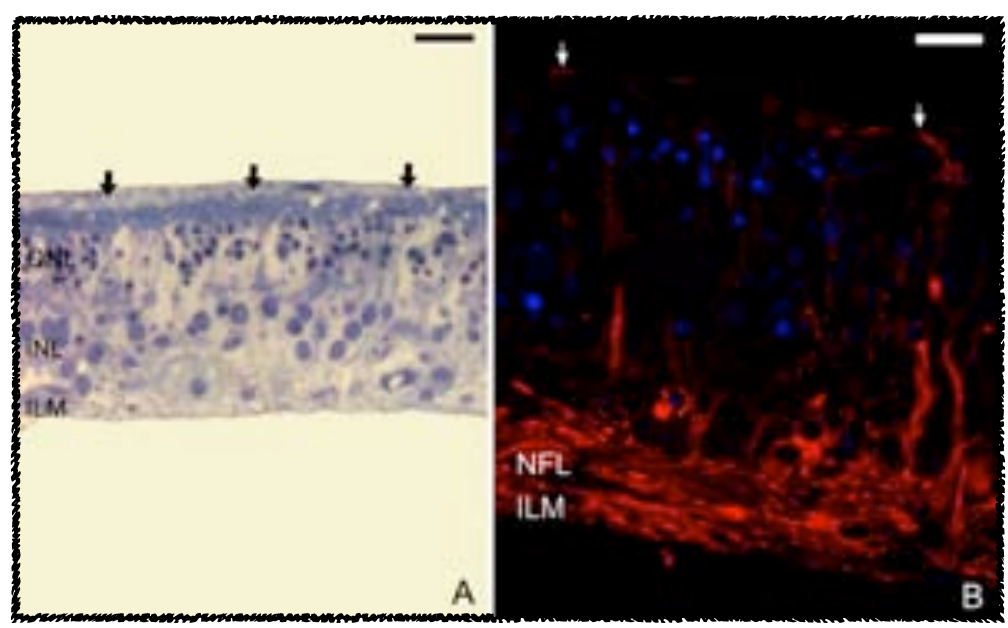

Figura 6.2.5 Tinción con Azul de Toluidina ( $A$ ), y distribución de la GFAP (B, rojo) en explantes cultivados durante 9 días, presentando una gran desorganización tisular. Los núcleos celulares se muestran teñidos con DAPI (B, azul). ONL: capa nuclear externa; INL: capa nuclear interna; NFL: capa de fibras del nervio óptico; ILM: membrana limitante interna. Barras de escala: $20 \mu \mathrm{m}$.

\subsection{Caracterización histológica e inmunohistoquímica de}

\section{los explantes neurorretinianos cultivados con PBMCs}

\section{Obtención y evaluación histológica de los PBMCs:}

De cada muestra sanguínea se obtuvieron una media de $15 \times 10^{6} \mathrm{PBMCs} / \mathrm{mL}$, presentando éstos una viabilidad celular superior al 90\%.

Las extensiones celulares de una gota de PBMCs sobre porta, teñidos mediante la técnica de Giemsa, mostraron la presencia de linfocitos (Fig. 6.3.1A flechas azules) y monocitos (Fig. 6.3.1A flechas rojas) en la fracción celular.

Los PBMCs cultivados en placa durante dos días, tras ser teñidos con Giemsa, revelaron que la mayoría de las células presentes eran monocitos que se estaban diferenciando hacia macrófagos, al observar células de mayor tamaño, con un mayor porcentaje de citoplasma y con núcleos de morfología arriñonada (Fig. 6.3.1B flechas rojas). 


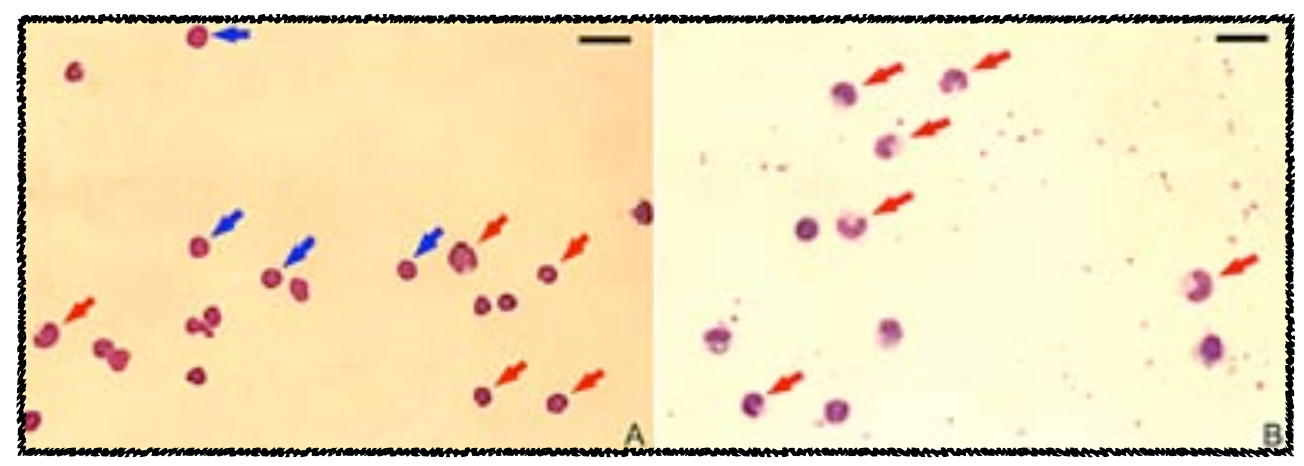

Figura 6.3.1 Tinción con Giemsa de las extensiones celulares de los PBMCs (A) y de los PBMCs cultivados durante dos días (B). Flechas azules: linfocitos; Flechas rojas: monocitos (A), monocitos/ macrófagos (B). Barras de escala: $20 \mu \mathrm{m}$.

\section{Evaluación histológica de los explantes cultivados con PBMCs:}

Los explantes cultivados en presencia de PBMCs no presentaron modificaciones significativas, en comparación con los controles, a los tres y seis días de cultivo. Sin embargo, a los nueve días (Fig. 6.3.2A) se apreció una mayor desorganización celular. Observándose, en comparación con los controles (Fig. 6.2.1C), una mayor reducción en el número de núcleos presentes en la ONL y en la INL; un marcado acortamiento de la OPL y de la IPL, casi inapreciables, apareciendo núcleos celulares en esta última; y la ausencia de núcleos en la GCL. Por otra parte, además del tejido neoformado que se apreció bordeando externamente a la OLM, se percibió una migración de núcleos hacia esta región (Fig. 6.3.2A flechas), quedando englobados en ese tejido. 


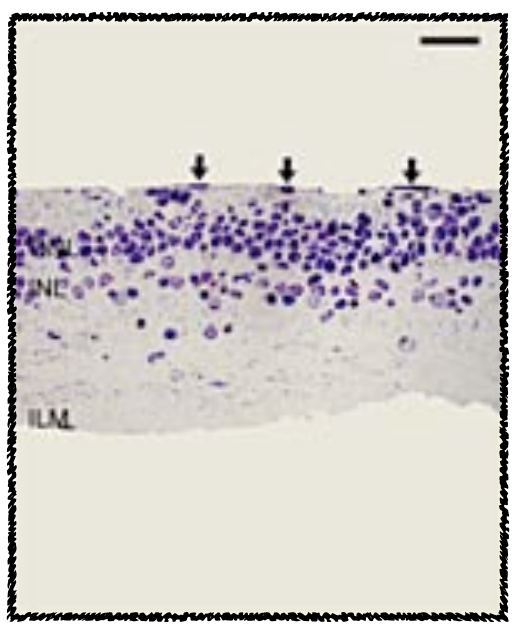

Figura 6.3.2A Tinción con Azul de Toluidina de los explantes cultivados con PBMCs durante 9 días. ONL: capa nuclear externa; INL: capa nuclear interna; ILM: membrana limitante interna. Barra de escala: $20 \mu \mathrm{m}$.

\section{Evaluación inmunohistoquímica de los explantes cultivados con PBMCs:}

Los explantes procesados e inmunomarcados para la detección de la GFAP, revelaron un aumento en la expresión de esta proteína e importantes cambios en las células de Müller a lo largo de todos los tiempos de estudio (Fig. 6.3.3A-C), en comparación con los controles (Fig. 6.2.2A-C). Progresivamente, se observó un aumento de la intensidad del marcaje en la NFL y en la GCL. Igualmente, se pudo apreciar como, en presencia de los PBMCs, las células de Müller presentaron un cuerpo celular más engrosado y repleto de filamentos intermedios $\mathrm{GFAP}^{+}$. Alcanzando éstos, a lo largo del citoplasma de las células de Müller, la ONL a los tres días (Fig. 6.3.3A) y la OLM a los seis días de cultivo (Fig. 6.3.3B), para finalmente atravesar esta capa, extendiendo, las células de Müller, múltiples de sus engrosadas prolongaciones celulares $\mathrm{GFAP}^{+}$por el supuesto área subretiniana, formando múltiples capas (Fig. 6.3.3C flechas). A los nueve días, se observó una notable reducción en el número de núcleos DAPI+. 


\section{Resultados}

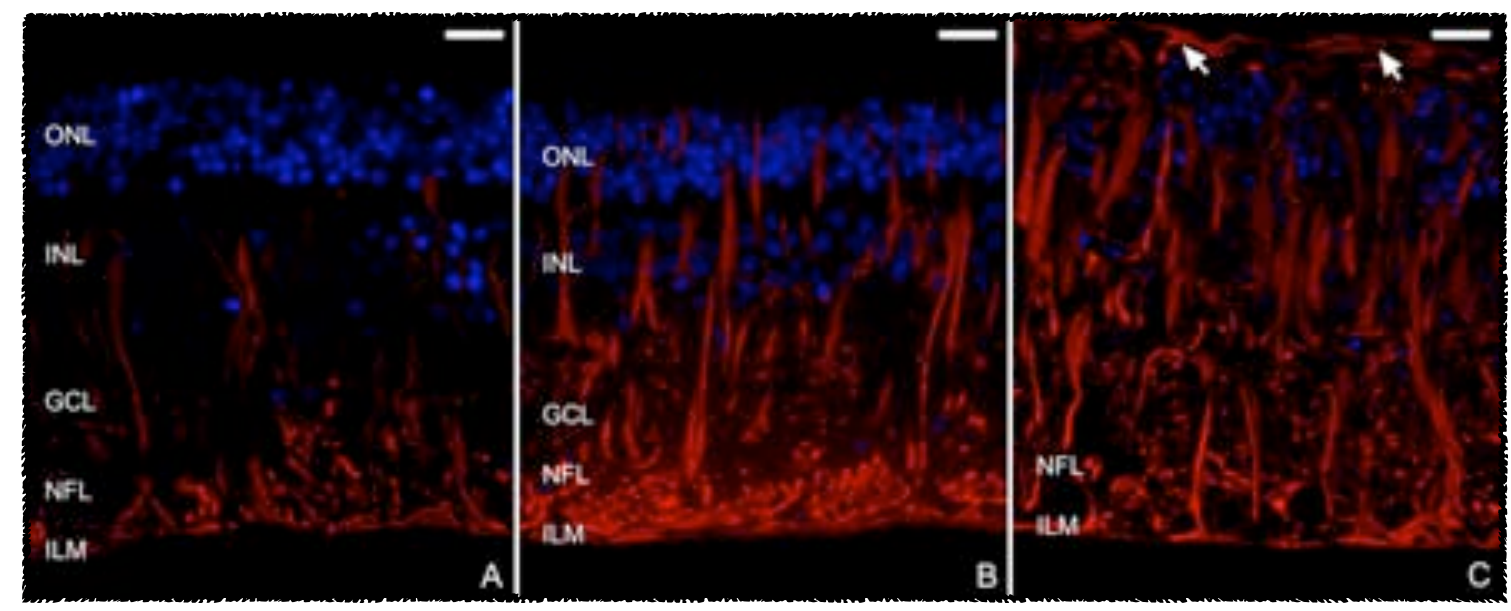

Figura 6.3.3 Distribución de la GFAP (rojo) en explantes cultivados con PBMCs durante $3(A), 6$ (B)

y 9 (C) días. Los núcleos celulares se muestran teñidos con DAPI (azul). ONL: capa nuclear externa; INL: capa nuclear interna; GCL: capa de las células ganglionares; NFL: capa de fibras del nervio óptico; ILM: membrana limitante interna. Barras de escala: $20 \mu \mathrm{m}$.

Las muestras doblemente inmunomarcadas y evaluadas mediante microscopía confocal, mostraron mayor número de células de Müller expresando GFAP a los seis días, en comparación con el total $\mathrm{CRALBP}^{+}$(Fig. 6.3.4A), presentándose esta proteína en las capas retinianas más externas (Fig. 6.3.4A flechas) y alcanzando la OLM. Con respecto a los astrocitos, mantuvieron sus cuerpos celulares en la NFL (Fig. 6.3.4A asteriscos) pero sus prolongaciones ya se presentaron en las capas más externas durante este tiempo de estudio (Fig. 6.3.4A cabezas de flecha). Finalmente, a los nueve días, se apreció una retina totalmente desorganizada, con gran expresión de la GFAP en todo el parénquima retiniano, llegando a atravesar la OLM (Fig. 6.3.4B flechas). Los astrocitos mostraron sus prolongaciones extendiéndose por la región de la INL (Fig. 6.3.4B cabeza de flecha), y se apreció una disminución en la expresión de la CRALBP, sobre todo en la porción retiniana más externa. 


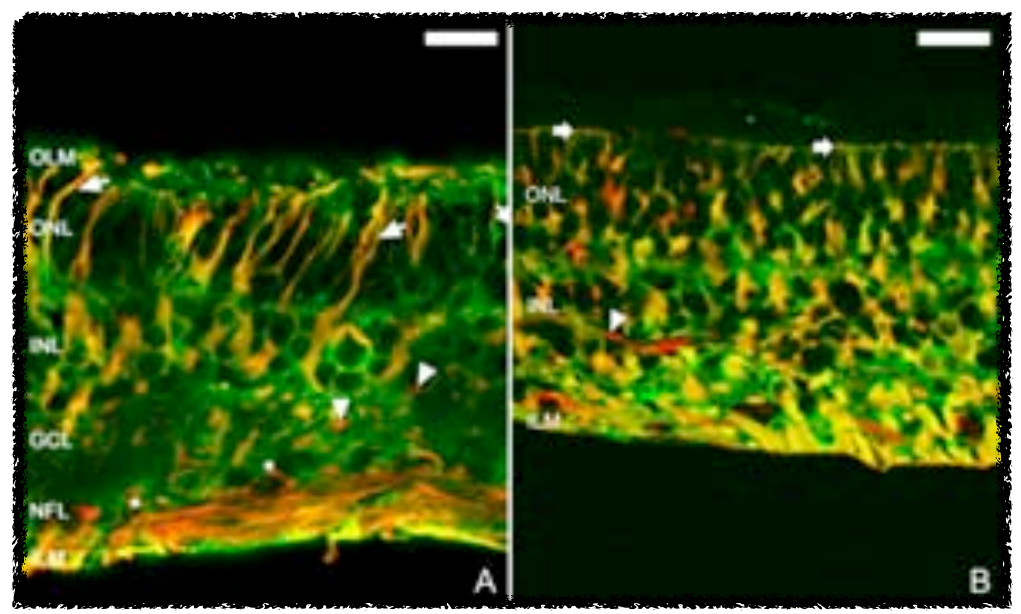

Figura 6.3.4 Distribución de la GFAP (rojo) y de la CRALBP (verde), evaluadas mediante microscopía confocal, en explantes cultivados con PBMCs durante 6 (A) y 9 (B) días. OLM: membrana limitante externa; ONL: capa nuclear externa; INL: capa nuclear interna; GCL: capa de las células ganglionares; NFL: capa de fibras del nervio óptico; ILM: membrana limitante interna. Barras de escala: $20 \mu \mathrm{m}$.

\subsection{Caracterización inmunohistoquímica de los explantes}

\section{neurorretinianos cultivados con monocitos CD14+}

\section{Obtención de los monocitos CD14+:}

De cada muestra sanguínea se obtuvieron una media de $100 \times 10^{6} \mathrm{PBMCs} / \mathrm{mL}$, presentando una viabilidad celular superior al 98\% y con una riqueza en monocitos, determinada mediante citometría de flujo, cercana al 38\% (Fig. 6.4.1A).

Partiendo de 20×106 PBMCs, tras deplección celular magnética, se obtuvieron $12 \times 10^{6}$ células, presentando una viabilidad celular del 98\% y con una riqueza en monocitos del $81 \%$ (Fig. 6.4.1B). A partir de éstas y tras selección celular magnética, se obtuvieron 9x106 células, presentando una viabilidad celular del 95\% y con una pureza en monocitos CD $14^{+}$del $95,5 \%$ (Fig. 6.4.1C). 


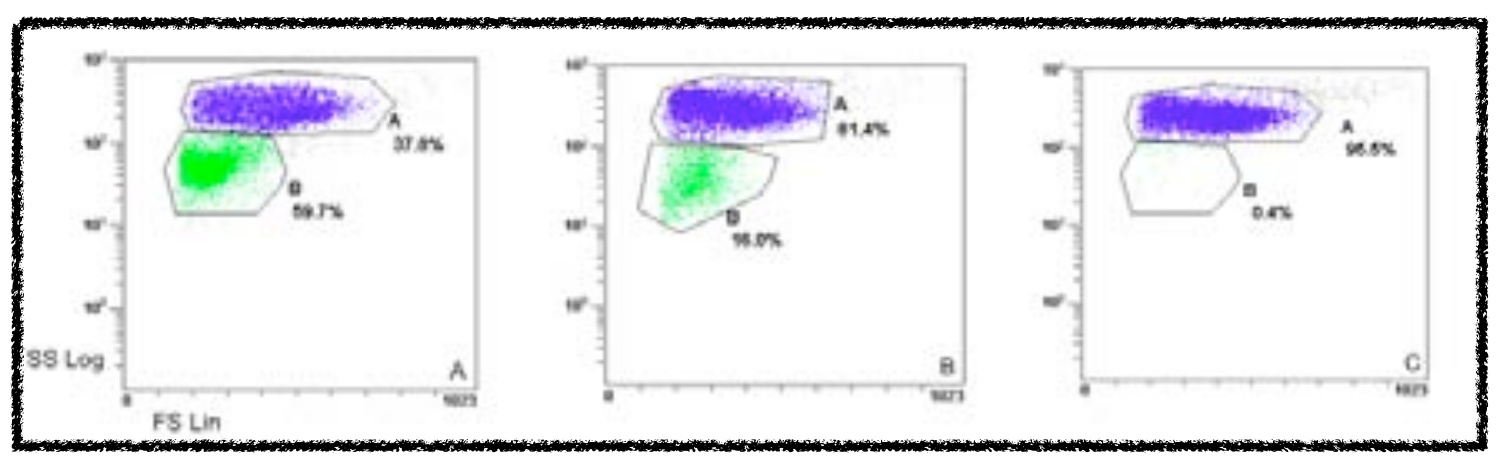

Figura 6.4.1 Fracciones celulares de los PBMCs (A), tras deplección (B) y selección celular magnética $(C)$, relacionando la complejidad celular (SS, del inglés, Side Scatter) con el tamaño celular (FS, del inglés, Forward Scatter). Se representan la fracción linfocítica (verde) y la monocítica (azul).

\section{Evaluación histológica e inmunocitoquímica de los monocitos CD14+:}

Los monocitos $\mathrm{CD} 14^{+}$tras ser cultivados en placa durante cuatro días, en el medio de cultivo retiniano, mostraron, mediante tinción con Giemsa (Fig. 6.4.2), características morfológicas de macrófagos maduros, como son un gran tamaño celular, con abundante citoplasma, y con núcleos de morfología arriñonada.

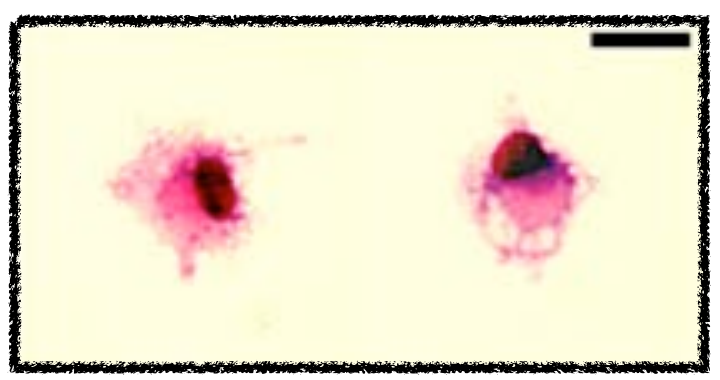

Figura 6.4.2 Tinción con Giemsa de monocitos CD14+ cultivados durante cuatro días. Barra de escala: $20 \mu \mathrm{m}$. 
Mediante técnicas de inmunocitoquímica, se reveló la expresión, por parte de las células, de las proteínas SWC3 (Fig. 6.4.3A,C\&D), característica de la línea monocítica porcina, y de la SWC9 (Fig. 6.4.3B-D), característica de los macrófagos porcinos maduros.

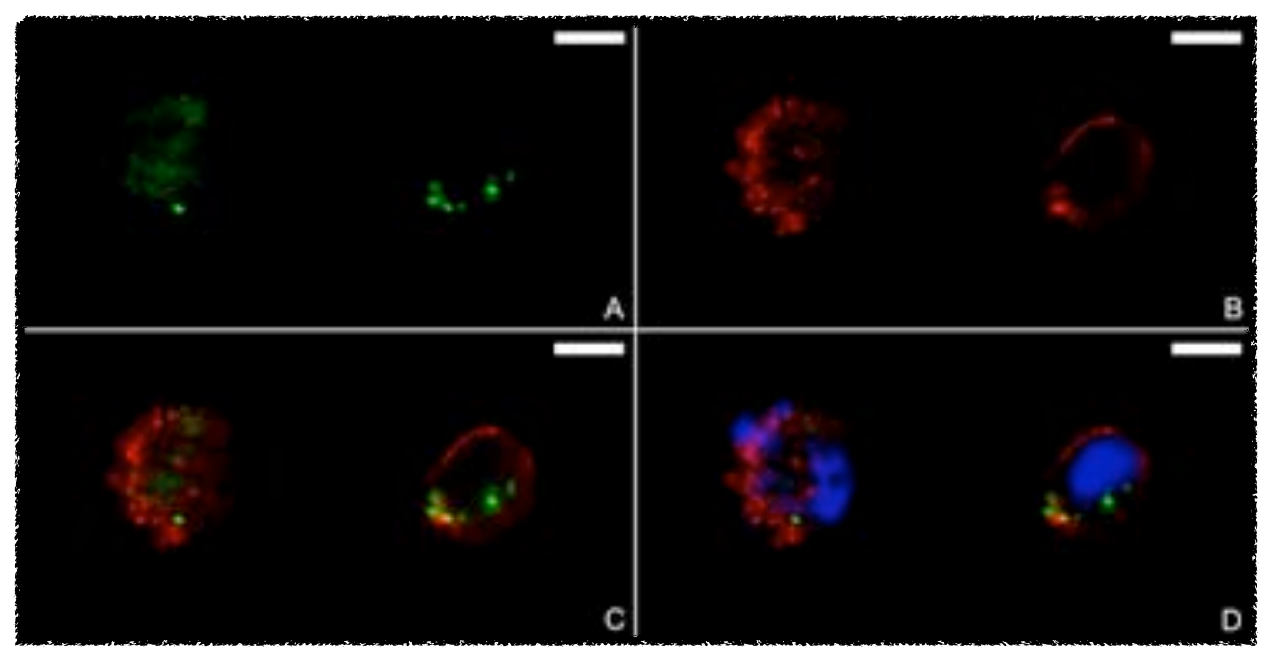

Figura 6.4.3 Distribución de la SWC3 ( $A, C \& D$, verde) y de la SWC9 (B-D, rojo) en monocitos $C D 14^{+}$ cultivados durante cuatro días. Los núcleos celulares se muestran teñidos con DAPI (D, azul). Barras de escala: $10 \mu \mathrm{m}$.

\section{Evaluación inmunohistoquímica de los explantes cultivados con}

\section{monocitos CD14+:}

Los explantes cultivados con monocitos $\mathrm{CD} 14^{+}$, procesados e inmunomarcados con anticuerpo frente a la GFAP, presentaron un progresivo aumento en la expresión de esta proteína a lo largo de las células de Müller. Apareciendo a nivel de la INL a los 3 días (Fig. 6.4.4A), en la ONL a los 6 días (Fig. 6.4.4B), y finalmente, atravesando la OLM e invadiendo, las prolongaciones $\mathrm{GFAP}^{+}$de las células de Müller, el área suretiniana, a los 9 días de cultivo (Fig. 6.4.4C flechas). Este patrón de expresión de la GFAP fue similar al observado en los controles (Fig. 6.2.2A-C). 


\section{Resultados}

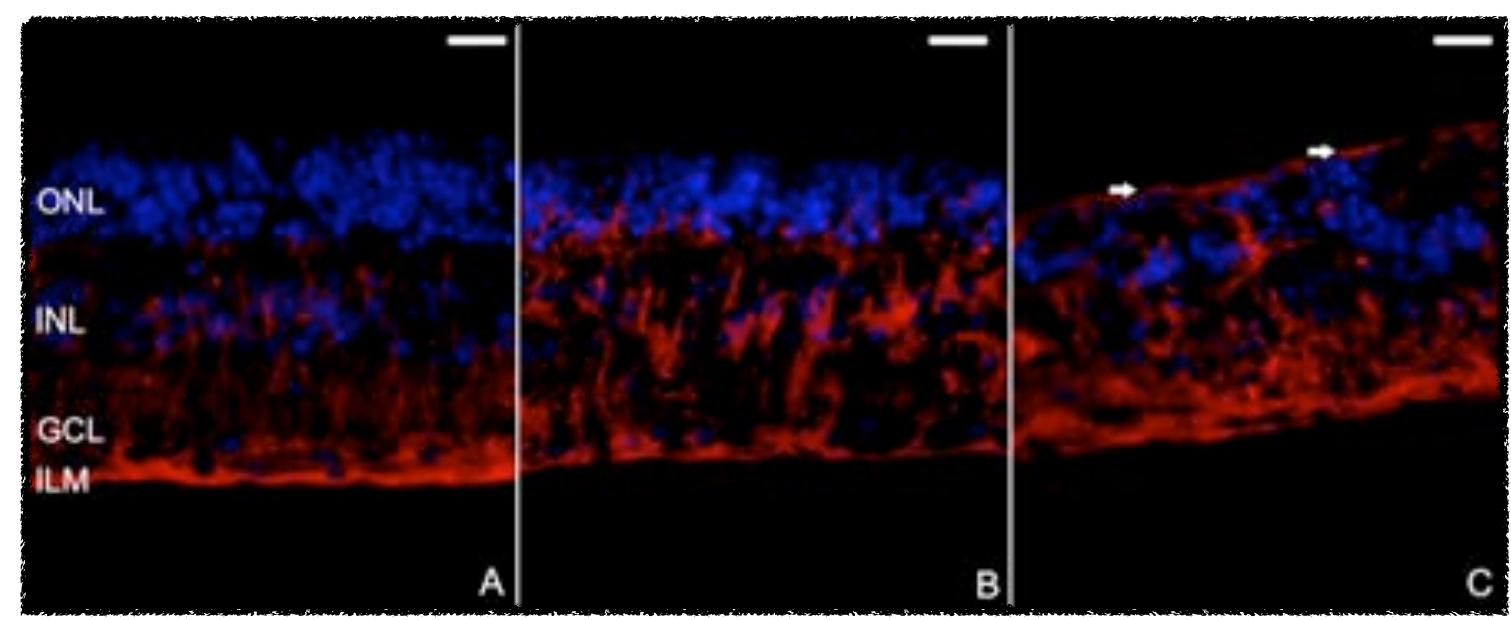

Figura 6.4.4 Distribución de la GFAP (rojo) en explantes cultivados con monocitos CD14+ durante 3 (A), 6 (B) y 9 (C) días. Los núcleos celulares se muestran teñidos con DAPI (azul). ONL: capa nuclear externa; INL: capa nuclear interna; GCL: capa de las células ganglionares; ILM: membrana limitante interna. Barras de escala: $20 \mu \mathrm{m}$.

\section{Niveles de TNF $\alpha$ en el medio de cultivo de los explantes cultivados}

\section{con monocitos CD14+:}

Los niveles promedio de TNF $\alpha$, detectados en el sobrenadante de los cultivos control, aumentaron desde valores no detectables en medio Neurobasal A suplementado, hasta 4,2 $( \pm 0,4) \mathrm{pg} / \mathrm{mL}$ en el día 1 de cultivo. No se detectó TNF $\alpha$ en los otros tiempos de estudio analizados (Fig. 6.4.5 línea verde).

Por el contrario, en el cultivo con monocitos CD14+ (Fig. 6.4.5 línea azul) se detectaron niveles de TNF $\alpha$ durante todo el experimento, aumentando hasta $7,0( \pm 1,6) \mathrm{pg} / \mathrm{mL}$ el día 1 , 11,6 $( \pm 1,9) \mathrm{pg} / \mathrm{mL}$ el día 3 y llegando a un máximo de $13,7( \pm 3,0) \mathrm{pg} / \mathrm{mL}$ el día 5 de cultivo. A los 7 días, la concentración de TNF $\alpha$ se mantuvo en cotas bastante similares, $12,9( \pm 2,7)$ pg/ mL, para disminuir brúscamente hasta un mínimo de $6,8( \pm 3,0) \mathrm{pg} / \mathrm{mL}$, detectado a los 9 días de cultivo con monocitos CD14+. 


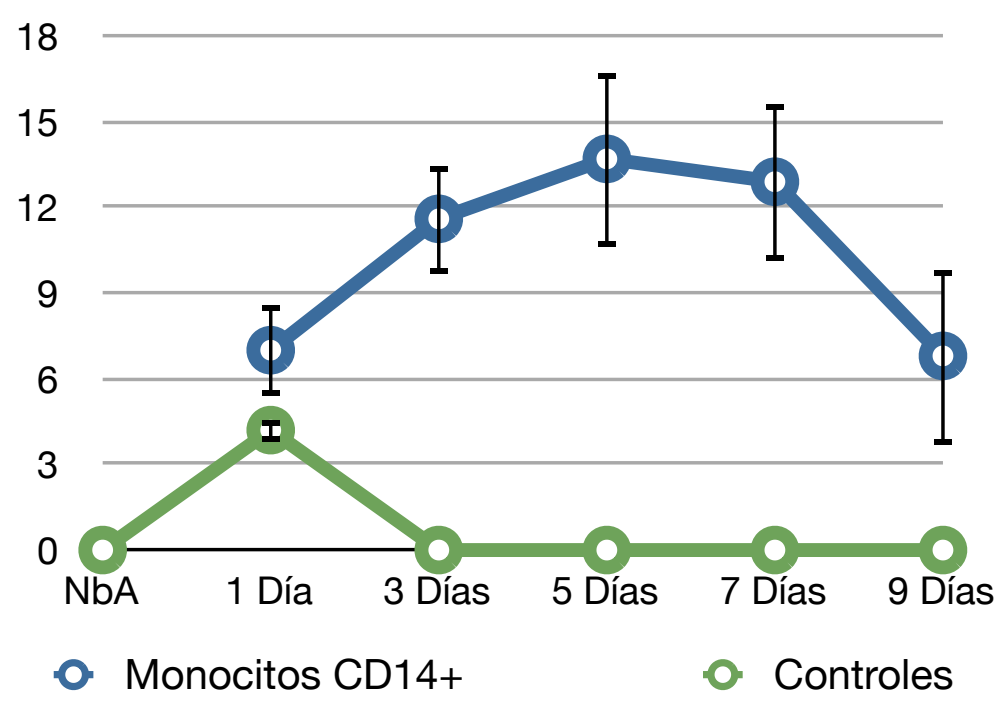

Figura 6.4.5 Valores promedio y desviación estándar de los niveles de TNFa ( $\mathrm{pg} / \mathrm{mL})$ en Neurobasal A suplementado ( $\mathrm{NbA}$ ), en el sobrenadante de los explantes control (línea verde), y en el cultivo con monocitos CD14+ (línea azul), en los días 1, 3, 5, 7 y 9 de cultivo.

\subsection{Caracterización inmunohistoquímica de los explantes}

\section{neurorretinianos cultivados con TNF $\alpha$}

\section{Evaluación inmunohistoquímica de los explantes cultivados durante}

\section{dos días con diferentes dosis de TNF $\alpha$ :}

Los explantes control de este experimento revelaron expresión de la GFAP a nivel de la INL (Fig. 6.5.1A flecha), lo que no se apreció en las muestras de retinas recién desprendidas (Fig. 6.1C). Asimismo, la expresión de la CRALBP se mantuvo en niveles similares a los presentes en las citadas mestras (Fig. 6.1C).

En lo que respecta a los explantes cultivados con TNF $\alpha$, las dosis de 25 y $50 \mathrm{pg} / \mathrm{mL}$ no revelaron cambios apreciables en los patrones de expresión de la GFAP y de la CRALBP (Fig. 6.5.1B\&C), en comparación con el citado control (Fig. 6.5.1A) a los dos días de cultivo. Sin embargo, utilizando mayores concentraciones de TNF $\alpha$, entre 100 y 400 pg/mL, la expresión 


\section{Resultados}

de la GFAP se hizo más evidente, presentándose en las porciones externas de las células de Müller (Fig. 6.5.1D-F). Además, con la máxima dosis de TNF $\alpha$ utilizada, $400 \mathrm{pg} / \mathrm{mL}$, aparecieron filamentos intermedios $\mathrm{GFAP}^{+}$en las células de Müller a nivel de la ONL (Fig. 6.5.1F flechas).

No se apreciaron modificaciones aparentes en lo que respecta a la expresión de la CRALBP con ninguna de las concentraciones de TNF $\alpha$ utilizadas en estos cultivos de dos días y, en general, la morfología y la estructura retiniana se mantuvieron preservadas.

Los resultados de estos experimentos permitieron determinar la cocentración mínima de TNF $\alpha(100 \mathrm{pg} / \mathrm{mL})$ capaz de originar cambios en la expresión de la GFAP. Dicha dosis se tomó como referencia para el desarrollo de los estudios posteriores.

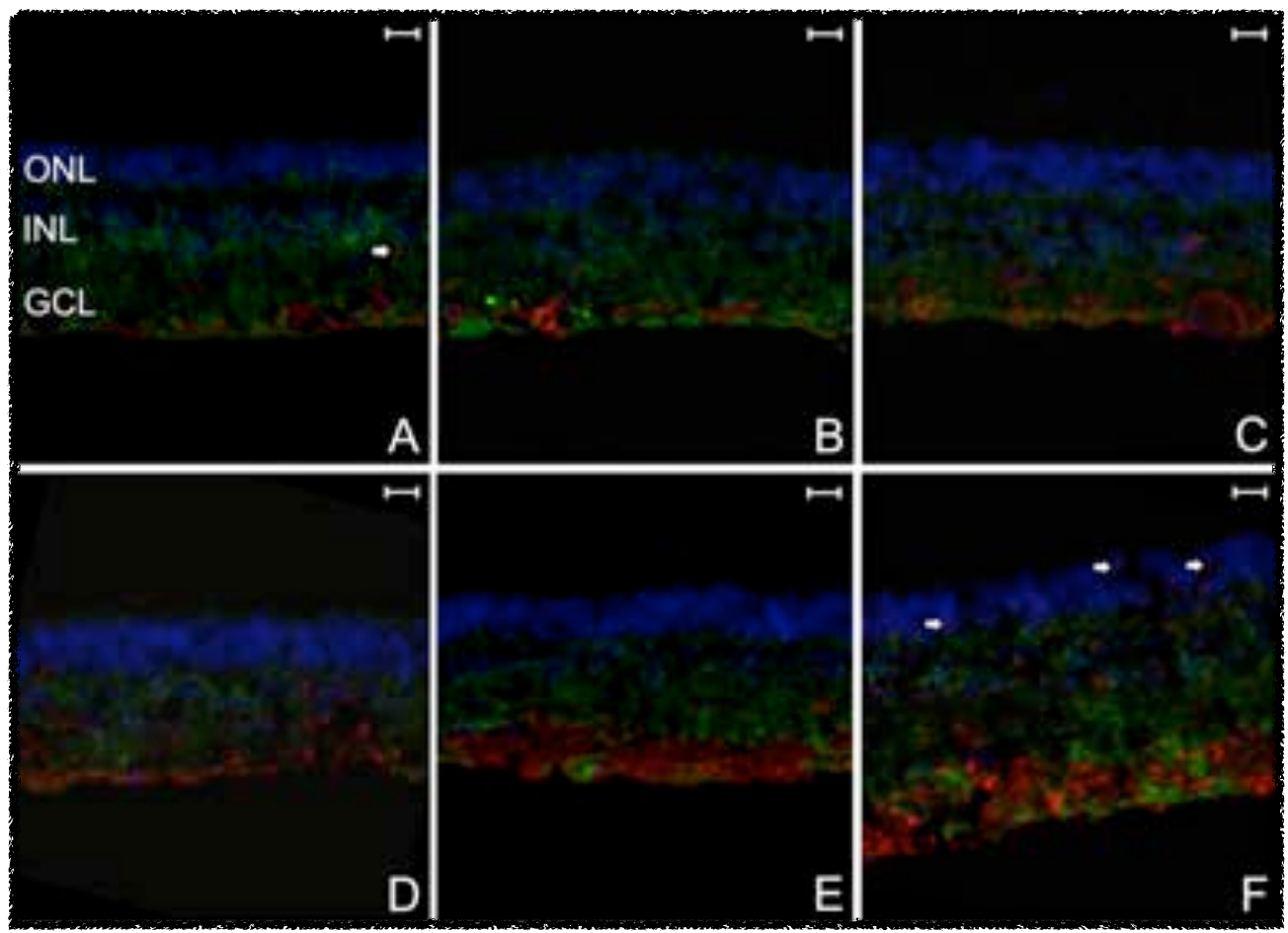

Figura 6.5.1 Distribución de la GFAP (rojo) y de la CRALBP (verde) en explantes cultivados como control (A) y con 25 (B), 50 (C), 100 (D), 200 (E) y 400 pg/mL (F) de TNFa, durante dos días. Los núcleos celulares se muestran teñidos con DAPI (azul). ONL: capa nuclear externa; INL: capa nuclear interna; GCL: capa de las células ganglionares. Barras de escala: $20 \mu \mathrm{m}$. 


\section{Evaluación inmunohistoquímica de los explantes cultivados con}

\section{$100 \mathrm{pg} / \mathrm{mL}$ de TNF $\alpha:$}

Los explantes cultivados con $100 \mathrm{pg} / \mathrm{mL}$ de TNF $\alpha$ revelaron cambios en la expresión de la GFAP (Fig. 6.5.2A-C) en comparación con los controles (Fig. 6.2.3A-C).

A los 3 días, un número considerable de células de Müller mostraron expresión de la GFAP en sus cuerpos celulares, a nivel de la OPL (Fig. 6.5.2A). La expresión de la CRALBP se mantuvo en niveles similares a los controles (Fig. 6.2.3A).

A los 6 días, la estructura retiniana comenzó a desorganizarse (Fig. 6.5.2B). Las capas celulares más externas perdieron la típica compactación nuclear, apareciendo un aumento en los niveles de la GFAP en las células de Müller, detectándose esta proteína a nivel de la ONL. La expresión de la CRALBP fue prácticamente inapreciable, siendo solo detectable en algunas células de Müller en la INL.

Al final del cultivo, 9 días, la inmunoreactividad para la GFAP se hizo aparente en un gran número de células de Müller (Fig. 6.5.2C). Se redujo el número de núcleos DAPI ${ }^{+}$ presentes en la INL, y los situados en la ONL aparecieron separados entre sí, estando rodeados por procesos $\mathrm{GFAP}^{+}$de las células de Müller. Estas prolongaciones llegaron a atravesar la OLM en algunos puntos (Fig. 6.5.2C flecha), comenzando su extensión por el área subretiniana. En este tiempo de estudio no se detectó la expresión de la CRALBP. 


\section{Resultados}

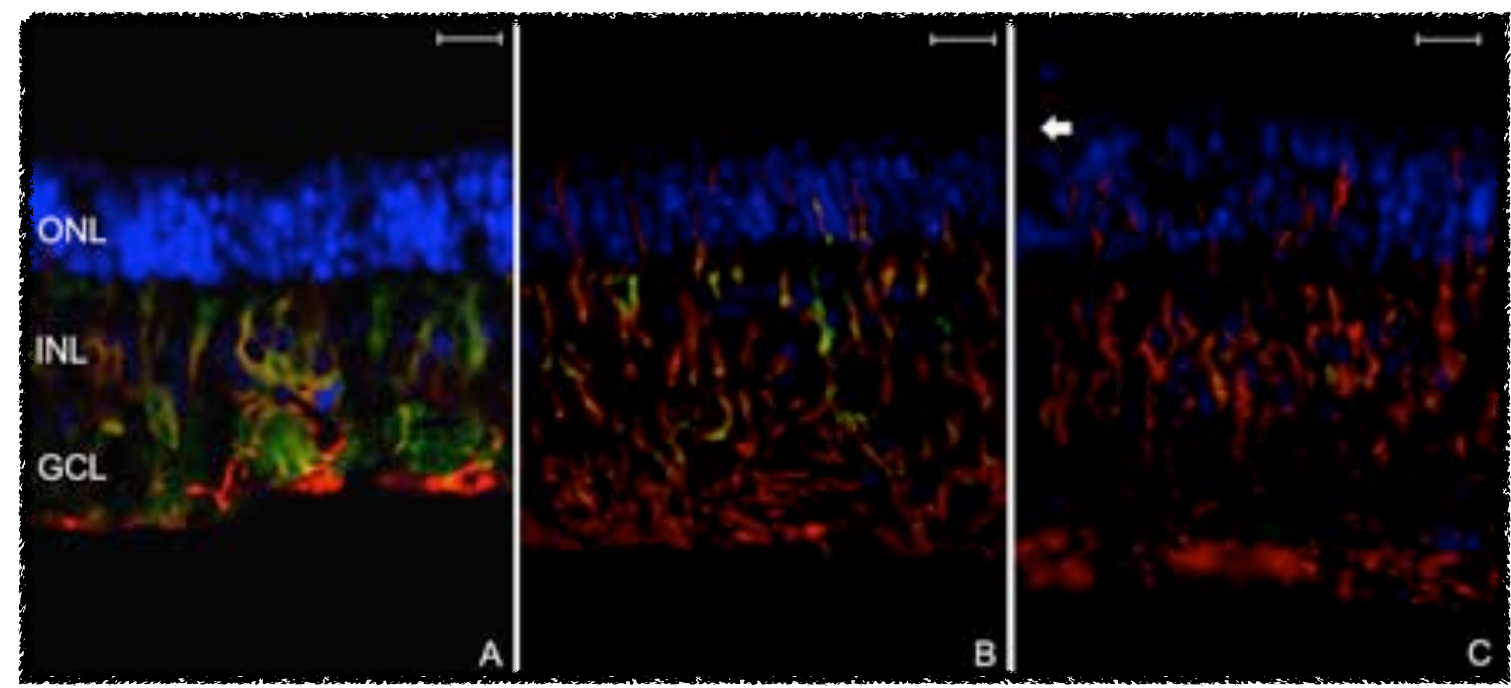

Figura 6.5.2 Distribución de la GFAP (rojo) y de la CRALBP (verde) en explantes cultivados con $100 \mathrm{pg} / \mathrm{mL}$ de TNFa durante 3 (A), 6 (B) y 9 (C) días. Los núcleos celulares se muestran teñidos con DAPI (azul). ONL: capa nuclear externa; INL: capa nuclear interna; GCL: capa de las células ganglionares. Barras de escala: $20 \mu \mathrm{m}$.

\subsection{Caracterización inmunohistoquímica de los explantes}

\section{neurorretinianos cultivados con adalimumab}

Los explantes cultivados con $10 \mu \mathrm{g} / \mathrm{mL}$ de adalimumab (Fig. 6.6A-C), procesados y doblemente inmunomarcados con anticuerpos frente a la GFAP y a la CRALBP, revelaron una importante reducción en los niveles de expresión de la GFAP, tanto a los 3, como a los 6 y 9 días de cultivo, en comparación con los controles (Fig. 6.2.3A-C). En estos experimentos, los niveles de expresión de la GFAP se mostraron similares a los observados en las retinas recién desprendidas (Fig. 6.1C). Finalmente, a los 9 días de cultivo, se apreciaron pequeñas regiones celulares $\mathrm{GFAP}^{+}$en la zona de la INL (Fig. 6.6C flechas), detectándose una leve desestructuración de las capas retinianas más externas (ONL). Los niveles de expresión de la CRALBP se mantuvieron aparentemente constantes durante el cultivo (Fig. 6.6A-C), mostrando niveles de expresión similares a los observados en retinas recién desprendidas (Fig. 6.1C). 


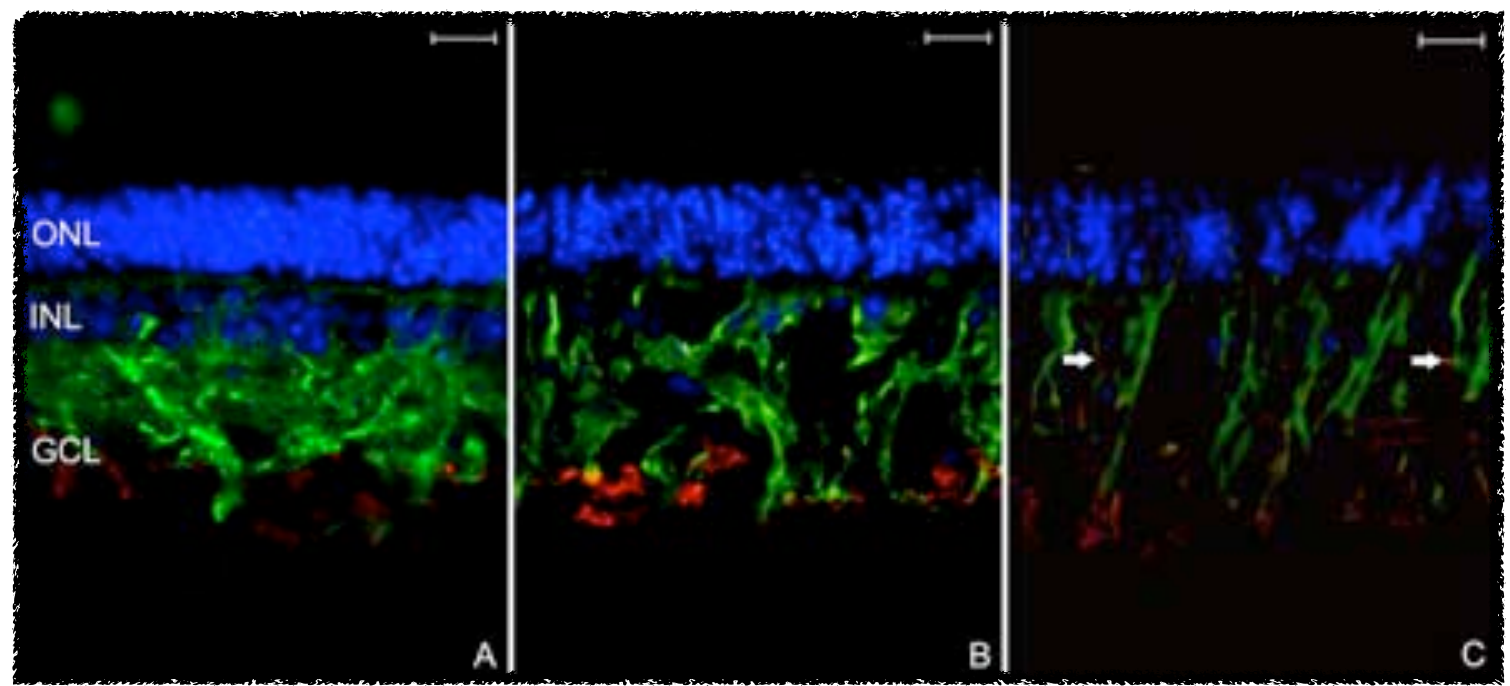

Figura 6.6 Distribución de la GFAP (rojo) y de la CRALBP (verde) en explantes cultivados con 10 $\mu \mathrm{g} / \mathrm{mL}$ de adalimumab durante $3(A), 6$ (B) y 9 (C) días. Los núcleos celulares se muestran teñidos con DAPI (azul). ONL: capa nuclear externa; INL: capa nuclear interna; GCL: capa de las células ganglionares. Barras de escala: $20 \mu \mathrm{m}$.

\subsection{Caracterización inmunohistoquímica de los explantes}

\section{neurorretinianos cultivados con $\mathrm{TNF} \alpha /$ adalimumab}

Los explantes cultivados con $100 \mathrm{pg} / \mathrm{mL}$ de TNF $\alpha$ y $10 \mu \mathrm{g} / \mathrm{mL}$ de adalimumab (Fig. 6.7A-C), procesados y doblemente inmunomarcados, revelaron unos patrones de expresión de la GFAP y de la CRALBP, a los tres y a los seis días de cultivo (Fig. 6.7A\&B), similares a los mostrados por los explantes cultivados solo con adalimumab (Fig. 6.6A\&B). Comparados con los controles (Fig. 6.2.3A\&B) y con los explantes cultivados con 100 pg/mL de TNF $\alpha$ (Fig. 6.5.2A\&B), la expresión de la GFAP se presentó notablemente reducida, mientras que la de la CRALBP y la organización retiniana se mantuvieron mejor conservadas, pudiendo compararse con los patrones mostrados por las retinas recién desprendidas (Fig. 6.1C). A la finalización del cultivo, 9 días, la expresión de la GFAP permaneció en niveles menores a los controles (Fig. 6.2.3C), sin embargo, comenzaron a observase pequeñas porciones celulares $\mathrm{GFAP}^{+}$ atravesando la ONL (Fig. 6.7C flechas). En este tiempo de estudio, la CRALBP continuó siendo 


\section{Resultados}

expresada por las células de Müller, y comenzó a percibirse cierto grado de desorganización retiniana, haciéndose ésta más notable en las capas externas.

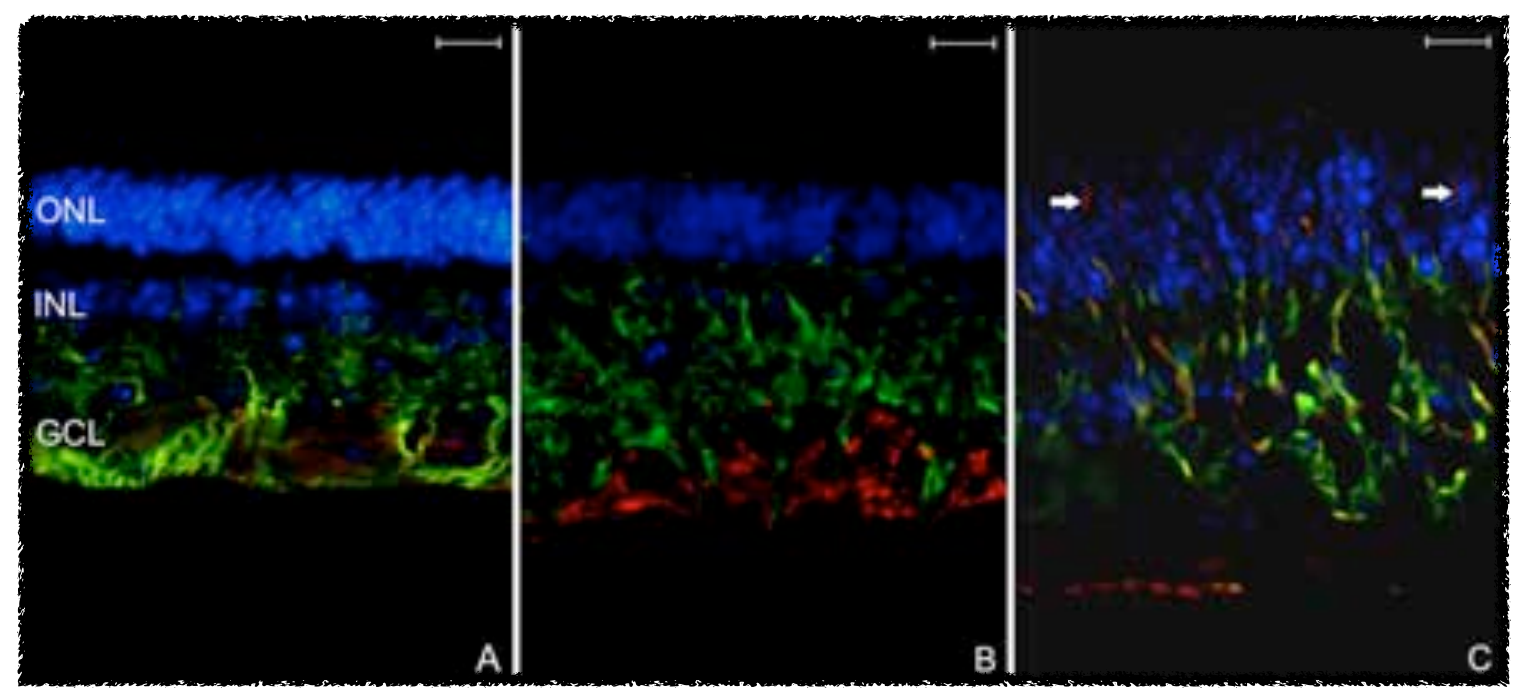

Figura 6.7 Distribución de la GFAP (rojo) y de la CRALBP (verde) en explantes cultivados con 100 pg/mL de TNFa y $10 \mu \mathrm{g} / \mathrm{mL}$ de adalimumab durante $3(A), 6(B)$ y $9(C)$ días. Los núcleos celulares se muestran teñidos con DAPI (azul). ONL: capa nuclear externa; INL: capa nuclear interna; GCL: capa de las células ganglionares. Barras de escala: $20 \mu \mathrm{m}$.

\subsection{Evaluación del espesor de los explantes}

\section{neurorretinianos durante los cultivos}

Los explantes mostraron una reducción del espesor retiniano a lo largo del tiempo de cultivo en comparación con las muestras recién desprendidas, que revelaron un grosor medio de $200,7( \pm 14,3) \mu \mathrm{m}$.

Las medidas del espesor de los explantes neurorretinianos, a lo largo de las diferentes condiciones de cultivo, se resumen y se representan en la tabla y en la gráfica siguientes (Fig. 6.8.1 у 6.8.2). 


\begin{tabular}{|c|c|c|c|c|}
\hline & Post-DR & 3 días & 6 días & 9 días \\
\hline Control & \multirow{6}{*}{$200,7 \pm 14,3$} & $160,8 \pm 7,6$ & $107,5 \pm 6,3$ & $110,4 \pm 6,8$ \\
\hline PBMCs & & $156,5 \pm 9,3$ & $109,1 \pm 13,8$ & $104,2 \pm 12,0$ \\
\hline CD14+ & & $157,7 \pm 12,5$ & $108,9 \pm 7,9$ & $110,1 \pm 9,6$ \\
\hline TNFa & & $131,0 \pm 14,3$ & $114,7 \pm 10,5$ & $131,3 \pm 7,8$ \\
\hline Adalimumab & & $166,4 \pm 11,9$ & $118,7 \pm 7,1$ & $120,4 \pm 8,0$ \\
\hline $\begin{array}{c}\text { TNFa/ } \\
\text { Adalimumab }\end{array}$ & & $164,8 \pm 10,3$ & $116,1 \pm 10,3$ & $122,9 \pm 7,6$ \\
\hline
\end{tabular}

Figura 6.8.1 Medidas del espesor ( $\mu \mathrm{m})$ de las neurorretinas recién desprendidas y de los explantes cultivados como control y con PBMCs, con monocitos CD14+, con $100 \mathrm{pg} / \mathrm{mL}$ de TNFa, con $10 \mu \mathrm{g} /$ $\mathrm{mL}$ de adalimumab y con $100 \mathrm{pg} / \mathrm{mL}$ de TNFa más $10 \mu \mathrm{g} / \mathrm{mL}$ de adalimumab, durante 3, 6 y 9 días.

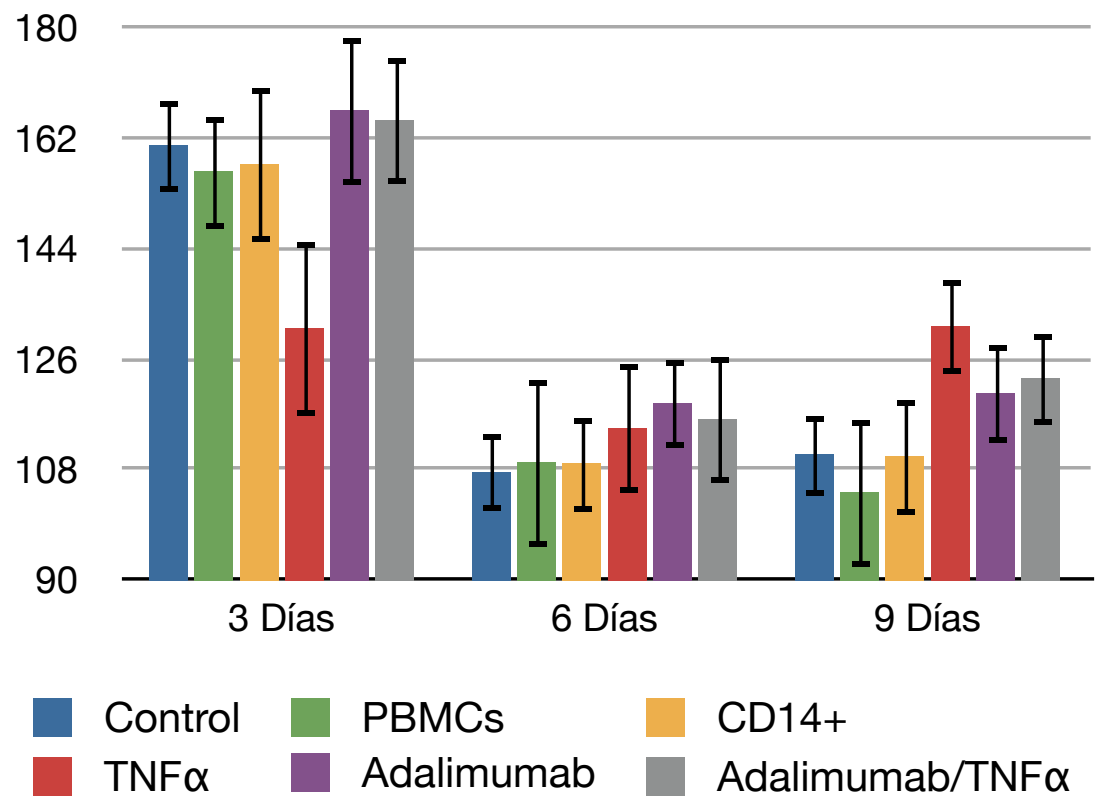

Figura 6.8.2 Valores promedio y desviación estándar del espesor $(\mu \mathrm{m})$ de los explantes cultivados como control y con PBMCs, con monocitos CD14+, con $100 \mathrm{pg} / \mathrm{mL}$ de TNFa, con $10 \mu \mathrm{g} / \mathrm{mL}$ de adalimumab y con $100 \mathrm{pg} / \mathrm{mL}$ de TNFa más $10 \mu \mathrm{g} / \mathrm{mL}$ de adalimumab, durante 3, 6 y 9 días. 


\section{Resultados}

Tomando como referencia los cambios observados en los controles, los explantes cultivados en presencia de PBMCs mantuvieron unos valores del espesor retiniano similares a éstos, tanto a los tres como a los seis días, para finalmente mostrar un mayor adelgazamiento. Por el contrario, los cultivados con monocitos $\mathrm{CD} 14^{+}$mostraron modificaciones semejantes a los controles en todos los tiempos de estudio evaluados.

Los cultivos con $100 \mathrm{pg} / \mathrm{mL}$ de TNF $\alpha$ revelaron una rápida reducción del espesor de la neurorretina, mostrando el grosor mínimo detectado a los tres días, $131,0( \pm 14,3) \mu \mathrm{m}$, para continuar disminuyendo hasta los seis días. Posteriormente, el tejido retiniano reveló un engrosamiento hasta los $131,3( \pm 7,8) \mu \mathrm{m}$, siendo este valor el máximo detectado a los nueve días de cultivo.

Por último, los explantes cultivados en presencia de $10 \mu \mathrm{g} / \mathrm{mL}$ de adalimumab o de 100 $\mathrm{pg} / \mathrm{mL}$ de $\mathrm{TNF} \alpha$ y $10 \mu \mathrm{g} / \mathrm{mL}$ de adalimumab, redujeron su espesor de una manera menos marcada, mostrando los mayores valores a los tres días de cultivo, $166,4( \pm 11,9)$ y 164,8 $( \pm 10,3) \mu \mathrm{m}$ respectivamente. A los seis y nueve días los espesores observados fueron similares entre ambos tiempos de estudio, situándose por encima de los detectados en los controles. 


\section{Discusiann}



Como ya se ha mencionado, el propósito de este estudio ha sido analizar el papel que juegan las células macrofágicas en el incremento de la respuesta gliótica por parte de las células de Müller, probablemente ligada a la acción del TNF $\alpha$, y evaluar el efecto potencial que pueden tener los agentes biológicos bloqueantes del TNF sobre dicha respuesta, en un modelo de cultivo organotípico de neurorretina porcina.

No obstante, en éste, como en todo trabajo, existen una serie de limitaciones que deben ser tenidas en cuenta a la hora de interpretar los resultados, algunas de las cuales se incluyen y discuten a lo largo de este capítulo.

\subsection{Discusión del material y método}

\subsubsection{Elección del modelo de cultivo organotípico de}

\section{neurorretina porcina}

En los seres humanos, muy pocas veces se pueden evaluar las modificaciones iniciales que sufre la retina tras un desprendimiento, siendo necesario recurrir a modelos experimentales que simulen estas condiciones patológicas para poder estudiarlas. Como ya se ha descrito, los modelos in vivo presentan determinadas limitaciones, ${ }^{76}$ y entre las técnicas in vitro, las basadas en cultivos celulares difieren considerablemente de la situación in vivo, debido a que las células son extraidas de su ambiente orgánico específico perdiendo el efecto de las interacciones intercelulares. ${ }^{115}$ Sin embargo, los sistemas de cultivo de explantes retinianos pueden reproducir las dinámicas funcionales de dicho tejido, de una manera más cercana a la realidad que los cultivos de células disociadas, ${ }^{116}$ habiéndose mostrado útiles para 
describir la diferenciación retiniana pre y postnatal temprana, los procesos patofisiológicos de las enfermedades retinianas degenerativas, y para determinar el efecto y la toxicidad de fármacos, de factores de crecimiento, y de células madre. ${ }^{175-190}$

Entre las múltiples especies animales empleadas en el estudio de las patologías retinianas, se optó por utilizar ojos porcinos para el desarrollo del modelo in vitro, porque comparten múltiples similitudes con los del ser humano, tales como el tamaño del globo ocular y del cristalino, el grosor y la rigidez escleral, y la estructura, la ultraestructura, el tamaño y la extensión retinianas. ${ }^{130}$ Los ojos porcinos poseen doble circulación retiniana, al contrario de los conejos, y carecen de zona tapetal, al contrario de los félidos, los cánidos y los bóvidos. ${ }^{132}$ La retina del cerdo tiene una alta densidad total de conos, ${ }^{130,131}$ concentrándose éstos en una gran banda horizontal, denominada area centralis, que atraviesa toda la extensión retiniana, pasando sobre el disco óptico, ${ }^{130}$ y que se corresponde con una alta densidad de células ganglionares. ${ }^{158,290}$ Esta banda no es atravesada por ninguno de los principales vasos retinianos, ${ }^{158,159}$ indicando que el area centralis en el cerdo es similar, en cierto modo, a la fóvea de la retina humana, ${ }^{130}$ teniendo en cuenta que no está deprimida, y que los cerdos carecen de la especialización foveolar de los seres humanos. ${ }^{130,132}$ Igualmente, la retina del cerdo tiene una densidad de bastones similar al humano, ${ }^{132}$ al contrario de otros animales previamente utilizados en el estudio de la patología retiniana, como la ardilla terrestre californiana, cuya retina está constituida solo por conos, ${ }^{291,292}$ o el gato, cuya retina está constituida exclusivamente por bastones. ${ }^{293}$

Por su parte, el modelo de cultivo organotípico de neurorretina de cerdo ya había sido caractarizado previamente, ${ }^{77}$ revelando cierto grado de similitud, en cuanto a los cambios a nivel retiniano, con los modelos experimentales de DR in vivo, 17, 31, 132, 294 siendo particularmente parecidos los observados en las capas retinianas externas. Sin embargo, hay que tener en cuenta, que las alteraciones estructurales observadas en la retina interna 
seguirían un patrón más cercano al originado por la axotomía y la isquemia que se provocan en este modelo. Por otra parte, está basado en el cultivo aislado de la neurorretina, careciendo por tanto, del sustento proporcionado por el vítreo, implicado en el metabolismo de las capas más internas de la retina; del importante papel que juega el EPR para el mantenimiento de la función retiniana; y de la vascularización e irrigación aportadas por la circulación retiniana y por la coroidea. Además, tanto el vítreo como el EPR están directamente implicados en el desarrollo de patologías retinianas, ya que el vítreo contribuye a la formación de las membranas epirretinianas, mientras que las células del EPR tienen la capacidad de diferenciarse y de migrar al parénquima retiniano tras el DR.

Otras opciones, no utilizadas en este estudio, son los modelos de cultivo de neurorretina de cerdo con parches de EPR-coroides o el cultivo en perfusión de explantes de neurorretina-EPR, pero además de tener un desarrollo complejo, muestran unos patrones de degeneración celular similares al cultivo de las neurorretinas a lo largo del tiempo, aunque con un mejor mantenimiento general de la estructura retiniana. ${ }^{115,295}$

Por todo ello, se optó por utilizar un modelo de cultivo organotípico de neurorretina porcina para analizar la respuesta in vitro de las células gliales retinianas, principalmente de las células de Müller. Este modelo suma la ventaja que supone la fácil obtención de los ojos porcinos, y también de las muestras sanguíneas empleadas en este estudio, en un matadero local, así como su mínimo coste de adquisición.

Debido a que regionalmente en la extensión retiniana se pueden encontrar diferencias, tanto en el grosor del tejido retiniano como en el número de células presentes, se optó por utilizar explantes de la zona media de la retina, descartando las regiones más periféricas y la zona del nervio óptico, como han descrito otros autores. ${ }^{77,182,295-298}$ De este modo, se pueden obtener seis muestras homogéneas de 5 x $5 \mathrm{~mm}$, que permiten llevar a cabo estudios comparativos, sin embargo, no se puede descartar que algunas de las modificaciones 
celulares, o del espesor retiniano, descritas sean atribuibles a diferencias regionales. Igualmente, se evitaron bordes irregulares en los explantes, ya que estas porciones degenerarían rápidamente, y zonas con vasos visibles, para descartar los posibles efectos que, sobre los cambios retinianos observados, pudieran ejercer las células endoteliales en degeneración.

Los tiempos de estudio elegidos (3, 6 y 9 días de cultivo), se basaron en los experimentos previos descritos por Winkler y cols. ${ }^{77}$ Donde los explantes porcinos cultivados durante diez días mostraron unos patrones de degeneración muy heterogéneos, y tiempos de cultivo más prolongados, resultaron en una gran desorganización de la estructura retiniana, no permitiendo la identificación de las capas nucleares.

\subsubsection{Elección del medio de cultivo retiniano}

El medio Neurobasal A suplementado con B-27 y libre de suero fetal se considera una de las combinaciones más adecuadas para el cultivo de múltiples tipos neuronales, incluyendo los fotorreceptores. ${ }^{299}$ Sin embargo, en un cultivo organotípico de neurorretina tienen que recibir los suplementos adecuados tanto las células neuronales como las gliales, sabiendo que el medio más utilizado para el cultivo de estas últimas es DMEM suplementado con suero fetal, 164, 167 y que la combinación de Neurobasal A y B-27 limita considerablemente el mantenimiento de las células de Müller, ya que es necesario suero fetal para su supervivencia. 190,299

Por ello, se optó por una combinación de Neurobasal A, B-27 y suero fetal, que había sido utilizada previamente en el cultivo organotípico de retina de rata, ${ }^{300}$ y porque experimentos previos llevados a cabo por el Grupo de Retina del IOBA mostraron una mejor conservación morfológica de la retina, en comparación con la utilización de otras combinaciones libres de suero fetal, como Neurobasal A, DMEM/F12 y B-27 (datos no 
publicados).

No obstante, para minizar el efecto que los factores presentes en el suero fetal pudieran ejercer sobre las modificaciones retinianas, se redujo la concentración de éste a la mínima necesaria para el mantenimiento de las células gliales (2\%). ${ }^{116}$ Simultáneamente, se comenzó a utilizar suero fetal de origen porcino para favorecer la maduración de los monocitos cultivados con los explantes retinianos. ${ }^{275}$

\subsubsection{Elección de los métodos de obtención de los PBMCs}

Para la obtención de los PBMCs a partir de la sangre periférica porcina, se utilizó una modificación del método originalmente descrito por Boyum. ${ }^{280}$ Sin embargo, los resultados conseguidos con respecto al número de células $\left(15 \times 10^{6}\right.$ células $\left./ \mathrm{mL}\right)$ y su viabilidad (90\%) no se consideraron satisfactorios y se decidió optar por otro método de aislamiento. Así, en los experimentos posteriores encaminados a la obtención de monocitos $\mathrm{CD}_{14}{ }^{+}$, se empleó el método descrito por Gonzalez y colaboradores, ${ }^{281}$ obteniendo una mayor cantidad de células $\left(100 \times 10^{6}\right.$ células $\left./ \mathrm{mL}\right)$ y con unos porcentajes de viabilidad más elevados (98\%), lo que permitió añadir un mayor número de células a los cultivos organotípicos.

Las diferencias encontradas en estos resultados pueden atribuirse a que el primer método está descrito para la separación de sangre humana, utilizando un gradiente de Histopaque $^{\circledR}$, con una densidad de $1077 \mathrm{~g} / \mathrm{L}$, mientras que el descrito por Gonzalez y colaboradores, ${ }^{281}$ está desarrollado específicamente para la separación de PBMCs a partir de sangre de cerdo, utilizando un gradiente de Percoll ${ }^{\circledR}$, con una densidad de $1130 \mathrm{~g} / \mathrm{L}$. Además, este método se complementa con la sedimentación inicial y posterior lisado de los hematíes, para obtener una población de PBMCs más purificada.

Otra variación metodológica introducida simultáneamente con el cambio del método de extracción de los PBMCs, y que también podría haber influido en los resultados 
mencionados, fue la utilización de EDTA como agente anticoagulante, para llevar a cabo los estudios de las poblaciones celulares mediante citometría de flujo.

\subsubsection{Elección de la GFAP y de la CRALBP como proteínas a}

\section{evaluar en las células gliales}

Para el estudio de la gliosis reactiva durante los cultivos organotípicos se optó por valorar el aumento que exhiben los filamentos intermedios originados por la GFAP, siendo uno de los principales componentes de la compleja respuesta retiniana que se produce frente a estímulos patológicos. ${ }^{24-26}$ Aunque está considerada como una respuesta inespecífica, es la más sensible que puede ser utilizada como marcador celular precoz frente a un daño retiniano. Tras un DR hay un gran aumento en la cantidad de filamentos intermedios GFAP', revelando un proceso de gliosis en las células de Müller y en los astrocitos, ${ }^{25,282-284}$ mientras que en condiciones fisiológicas, se expresan en un nivel muy bajo o no se detectan en las células gliales de ojos sanos de mamíferos. ${ }^{301}$ De este modo, mediante la inmunodetección de la GFAP se puede valorar el grado de gliosis reactiva que se produce durante el transcurso del cultivo organotípico.

Pero la GFAP no solo se expresa en las células de Müller, ya que también está presente en los astrocitos, de modo que para poder diferenciar ambos tipos celulares, se hace necesario evaluar otra proteína expresada solamente por uno de éstos, como la CRALBP. Ésta es una proteina de unión a los retinoides e implicada en el metabolismo de la vitamina A, que se encuentra en las células de Müller pero no en los astrocitos de mamíferos adultos, donde solo está presente durante las dos primeras semanas postnatales. ${ }^{285,286}$ De este modo, utilizando dobles marcajes, se permite diferenciar a las células de Müller de los astrocitos. ${ }^{286,287}$ 
Para el estudio de los cambios glióticos en las células de Müller también se puede evaluar la expresión de otra proteína, la vimentina, que al igual que la GFAP, forma parte de los filamentos intermedios de las células gliales. Aparece en las células de Müller desde la ILM y la NFL hasta la ONL, siendo prácticamente imperceptible en los astrocitos y predominando su expresión sobre la GFAP en condiciones fisiológicas. No obstante, aunque aumenta su expresión tras el daño del parénquima retiniano, la proteína que predomina es la GFAP, siendo más notables los incrementos en su expresión desde niveles basales en la ILM hasta llegar a ocupar el espacio subretiniano. ${ }^{77,302}$ Por esta razón, y para no encarecer innecesariamente los experimentos, no se ha estudiado el patrón de expresión de la vimentina.

En cuanto a la identificación de las células de Müller, otra de las proteínas más utilizadas es la S100, implicada en la fosforilación y ensamblaje de los filamentos intermedios. Esta proteína se expresa a lo largo de toda la extensión celular en condiciones fisiológicas, aumentando en las capas externas tras un daño retiniano, pero también aparece en los astrocitos, por lo que no permitiría discriminar entre ambos tipos celulares. ${ }^{303,304}$ Debido a esto, no se ha evaluado la expresión de la S100 en los experimentos.

Por último, otra de las técnicas que permite el estudio, en profundidad y con detalle, de los cambios estructurales retinianos es la microscopía electrónica. Sin embargo, esta técnica requiere un procesado de las muestras diferente al utilizado en este trabajo, donde principalmente se evaluó la expresión proteica mediante técnicas de inmunohistoquímica. 


\subsection{Discusión de los resultados}

\subsubsection{Puesta a punto y estandarización del cultivo}

\section{organotípico de neurorretina porcina}

Durante el cultivo, los hallazgos histológicos más relevantes fueron la degeneración temprana de los OS de los fotorreceptores, el acortamiento de las capas plexiformes, unido a la reducción del grosor retiniano, la vacuolización de la GCL, la progresiva muerte celular, y finalmente, la aparición de restos tisulares sobre la OLM.

A los tres y seis días de cultivo, la presencia de fragmentos de los OS de los fotorreceptores en la región subrretiniana fue disminuyendo, de una manera similar a lo que ocurre en los DR mantenidos experimentalmente durante un periodo de tiempo largo. ${ }^{17,}{ }^{31}$ In vivo, se atribuye la desaparición de estos restos celulares a la acción llevada a cabo por las células del EPR y por los macrófagos, que probablemente fagocitan los restos acumulados en esta zona. ${ }^{31}$ En este modelo ambos tipos celulares están ausentes, pudiendo desaparecer los mencionados fragmentos de los OS durante el procesado de las muestras.

Los núcleos observados en la IPL a los tres y seis días, podrían corresponderse con células de la INL o de la GCL que se desplazan hacia capas más internas o externas, respectivamente, debido al proceso de degeneración retiniana. Estas modificaciones no han sido descritas en otros modelos.

La rápida degeneración de las células ganglionares podría atribuirse a la axotomía y a la isquemia, producidas en el modelo utilizado, al igual que se ha descrito en el cultivo de retina de rata, donde las células ganglionares pierden sus axones y se reducen notablemente los neurofilamentos del cuerpo celular a los pocos días de cultivo. ${ }^{305,306}$

A los nueve días se percibe claramente un aumento en el grosor de la ONL, pudiendo atribuirse a la gliosis reaccional de las células de Müller, junto con el crecimiento de sus 
extensiones, para rellenar el espacio dejado por las neuronas en degeneración. Esto originaría la desorganización de la ONL mediante la pérdida de la compactación celular, resultando en un engrosamiento de dicha capa, y contribuyendo al aumento del grosor total del parénquima retiniano detectado en este tiempo de estudio.

Por su parte, la evaluación inmunohistoquímica reveló un rápido aumento en la expresión de la GFAP durante los primeros tres días de cultivo, presentándose esta proteína en el citoplasma de las células gliales a nivel de la ONL. Estos cambios que suceden de forma rápida, probablemente están asociados con la muerte temprana de los fotorreceptores y la alteración en los niveles de citoquinas que suceden tras el DR. ${ }^{307-310}$ A lo largo de los siguientes días, la expresión de la GFAP continuó aumentando en el citoplasma de las células de Müller, pero de forma más lenta. Lo que concuerda con los hallazgos observados en los modelos de DR experimental en gato, donde la respuesta de las células de Müller comenzó al día siguiente del DR, alcanzando la GFAP un alto grado de expresión entre los tres y los cuatro días postdesprendimiento, para posteriormente continuar aumentando mientras la retina permaneció desprendida. ${ }^{307}$ A los seis días, la expresión de la GFAP observada en los cultivos, a nivel de la OLM, estaba en consonancia con lo encontrado en estudios previos. ${ }^{17,}$ 77, 182 Finalmente, a los nueve días, la expresión de la GFAP aparece en las prolongaciones astrocitarias, presentes en las capas retinianas externas, y en las células de Müller, que rodean a los IS de los fotorreceptores e invaden el área subrretiniana, comenzando a establecer un tejido continuo adyacente a la OLM. Este tejido presentó unas características similares a las membranas subretinianas desarrolladas a los diez días en el cultivo organotípico de neurorretina porcina, ${ }^{77}$ y entre los siete y los veintiocho días tras el DR experimental en gatos. 17,311 
Las modificaciones celulares descritas durante el cultivo organotípico de la neurorretina porcina, son similares a las previamente observadas en modelos experimentales de DR , tanto in vivo como in vitro (Fig. 7.2.1).

\begin{tabular}{|c|c|c|c|c|}
\hline & Modelo actual & $\begin{array}{c}\text { Otros modelos } \\
\text { in vitro77 }\end{array}$ & $\begin{array}{c}\text { Modelos DR en } \\
\text { cerdo }{ }^{132,294}\end{array}$ & $\begin{array}{c}\text { Modelos DR en } \\
\text { gato }{ }^{17,31}\end{array}$ \\
\hline $\begin{array}{c}\text { Degeneración OS } \\
\text { temprana }\end{array}$ & + & + & + & + \\
\hline $\begin{array}{c}\text { Degeneración CG } \\
\text { temprana }\end{array}$ & + & + & No descrito & No descrito \\
\hline $\begin{array}{c}\text { Aumento GFAP } \\
\text { temprano }\end{array}$ & + & + & + & + \\
\hline $\begin{array}{c}\text { Reducción núcleos } \\
\text { ONL }\end{array}$ & + & No evaluado & + & + \\
\hline Núcleos en IPL & + & No descrito & No descrito & No descrito \\
\hline $\begin{array}{c}\text { Acortamiento IPL y } \\
\text { OPL }\end{array}$ & + & No evaluado & No evaluado & No evaluado \\
\hline $\begin{array}{c}\text { Pérdida sinapsis } \\
\text { neuronales }\end{array}$ & No evaluado & No evaluado & No evaluado & + \\
\hline $\begin{array}{c}\text { Reducción grosor } \\
\text { neurorretina }\end{array}$ & + & + & No evaluado & No evaluado \\
\hline $\begin{array}{c}\text { Aumento GFAP a lo } \\
\text { largo del tiempo de } \\
\text { DR }\end{array}$ & + & + & No descrito & + \\
\hline $\begin{array}{c}\text { Proliferación } \\
\text { células Müller } \\
\text { Castrocitarios }\end{array}$ & No evaluado & + & + & + \\
\hline $\begin{array}{c}\text { Formación } \\
\text { subretinianas }\end{array}$ & + & + & + & + \\
\hline
\end{tabular}

Figura 7.2.1 Representación de los principales hallazgos en el modelo actual, comparados con otros modelos previos de desprendimiento de retina (DR) in vitro e in vivo. OS: segmentos externos de los fotorreceptores. CG: células ganglionares; IPL: capa plexiforme interna; OPL: capa plexiforme externa; ONL: capa nuclear externa. 
Conjuntamente con la hipertrofia de las células gliales observada, no se puede descartar que en este modelo también se presenten procesos hiperplásicos en estas células, como se ha descrito previamente, ${ }^{17}$ pero no han sido evaluados en estos experimentos.

Macroscópicamente, al igual que en otros modelos de cultivo organotípico retiniano, ${ }^{77}$, 182 se pudo observar como los explantes mantuvieron su transparencia durante todo el periodo, siendo éste un signo claro de ausencia de contaminación tisular. Se produjo el adelgazamiento del espesor de la retina y la percepción de vasos sanguíneos, no apreciables durante la preparación de los explantes. Estos vasos estarían presentes en la retina desde el comienzo de los experimentos, no siendo visibles inicialmente debido a su localización en el espesor retiniano.

Los elevados patrones de desorganización observados en algunos de los explantes a los nueve días de cultivo, exclusivamente durante los primeros experimentos, estarían en consonancia con la heterogeneidad entre muestras descrita por Winkler y cols. en sus experimentos, a los diez días de cultivo. ${ }^{77}$

\subsubsection{Cultivo de los explantes neurorretinianos con}

\section{PBMCs}

Los explantes cultivados con PBMCs revelaron, en la evaluación histológica a los nueve días, un estado de degeneración retiniana más avanzado que en los controles, haciéndose difícil la diferenciación de las capas retinianas. Además de la reducción del espesor de la retina, destacó la ausencia de núcleos celulares en la GCL y la aparición de núcleos en la región de la IPL y en el área subretiniana, siendo aquí englobados por una formación tisular adyacente a la OLM. La presencia de núcleos en el área subretiniana sería compatible con la translocación de los núcleos de las células de Müller desde la INL a la ONL e incluso al espacio 
subretiniano, o con núcleos de fotorreceptores en degeneración expulsados hacia dicha región, modificaciones que han sido previamente descritas. ${ }^{17,}{ }^{77}$ Cabe mencionar, que tanto a los tres como a los seis días de cultivo con PBMCs no se apreciaron cambios histológicos en comparación con los controles, por ello, a partir de este experimento se decidió emplear únicamente el estudio inmunohistoquímico para evaluar los cambios retinianos, principalmente mediante la evaluación de la expresión de la GFAP.

Por el contrario, la evaluación inmunohistoquímica reveló modificaciones en la expresión de la GFAP en todos los tiempos de estudio. Se observó un notable aumento de la GFAP, perfilando los cuerpos celulares de unas células de Müller aparentemente más engrosadas, aunque no se han realizado estudios cuantitativos para confirmarlo, apreciando un mayor número de células de Müller $\mathrm{GFAP}^{+}$en comparación con el total de células CRALBP ${ }^{+}$ presentes en el parénquima retiniano. Sin embargo, no se detectó un aumento en la longitud de los filamentos intermedios $\mathrm{GFAP}^{+}$, a lo largo del citoplasma de las células de Müller. Finalmente, múltiples prolongaciones de estas células atravesaron la OLM y se extendieron por el área subretiniana, dispuestas en varias capas. Por otra parte, los astrocitos también revelaron cambios, como la presencia de extensiones celulares en las capas externas de la neurorretina a los seis días de cultivo.

Los cambios observados en estos experimentos pudieron ser debidos tanto a la interacción de las células de Müller con los macrófagos, que inducen gliosis reactiva, ${ }^{39}$ como con los linfocitos también presentes en los PBMCs. Sin embargo, en este modelo se considera a los PBMCs como una fuente mayoritaria de células macrofágicas, ya que fueron las predominantes en los cultivos en placa de los PBMCs. Por otra parte, las interacciones entre los macrófagos y las células gliales han sido propuestas como el origen de las modificaciones 
celulares que llevan al daño neuronal en múltiples enfermedades neurodegenerativas, incluyendo la neurodegeneración retiniana. Estudios previos han descrito como los macrófagos infiltrantes se asocian estrechamente, en el parénquima retiniano, con las células de Müller activadas. ${ }^{39} \mathrm{~A}$ raiz de estos hallazgos, se propuso que la célula de Müller es la diana inicial de las citoquinas producidas por los macrófagos infiltrantes, destacando al TNF $\alpha$ como uno de los principales implicados, ${ }^{39}$ y que otras células retinianas, como los fotorreceptores, serían dianas indirectas en este proceso, ya que no expresan receptores para la mayoría de las citoquinas secretadas por los macrófagos. ${ }^{62,312-316}$ Por tanto, las células de Müller podrían reducir la producción de factores neurotróficos necesarios para la supervivencia de los fotorreceptores, tras la activación por parte de los macrófagos. ${ }^{316-320}$ Estos hallazgos refuerzan la importancia que tendría bloquear las interacciones entre los macrófagos y las células de Müller, para el mantenimiento de la fisiología retiniana en determinadas enfermedades.

Además del papel que juegan los macrófagos en las modificaciones retinianas, también cabe mencionar la posible implicación que pueda tener la microglía en estos cambios, hecho que no ha sido evaluado específicamente en este trabajo, ya que se considera que los macrófagos infiltrantes tienen una capacidad destructiva superior a la de la microglía. ${ }^{40}$

Las células de la microglía son los macrófagos tisulares del sistema nervioso central y se activan en respuesta a pequeños cambios patológicos en el parénquima neural, protegiéndolo frente a la infección, la inflamación, la isquemia, los traumatismos, los tumores neurales y la neurodegeneración. ${ }^{321}$ La microglía se activa rápidamente, debido a su poder de respuesta frente a pequeños cambios moleculares en el microambiente celular, ${ }^{322,323}$ que preceden a los cambios estructurales en las células vecinas. La microglía en cultivo, tras ser estimulada, es capaz de producir citoquinas proinflamatorias y quimioquinas, ${ }^{324-327}$ al igual que ocurre in vivo tras un daño o durante un proceso inflamatorio. ${ }^{328}$ Se cree que la activación 
de la microglía beneficia la supervivencia de las células al retirar los restos celulares, sin embargo, también hay evidencias de que la microglía activada puede ser perjudicial para la supervivencia neuronal en el sistema nervioso central.

En la retina, la microglía se activa en respuesta a un daño, como el lumínico, la fotocoagulación láser y las cirugías intraoculares; ${ }^{320,329-331}$ o a enfermedades, como el glaucoma, la retinitis pigmentosa y la DMAE. ${ }^{332-335}$ En este tejido tiene capacidad de proliferar, de hipertrofiarse, y de migrar a las capas externas,332, 333, 336, 337 pudiendo modular la liberación de factores tróficos por parte de las células de Müller, ${ }^{320}$ incluyendo algunos que promoverían la supervivencia de los fotorreceptores y otros que promoverían su muerte celular. $^{338}$ En varias especies la microglía se activa tras un DR, pasando de una morfología ramificada a una ameboide, proliferando y migrando hacia la retina externa, situándose en regiones cercanas a las células de Müller reactivas. ${ }^{293}$ Sin embargo, tras un tiempo, la respuesta de estas células parece agotarse, reduciéndose su número y migrando de nuevo hacia las capas internas de la retina. ${ }^{293}$ Estas mismas modificaciones se han descrito en el cultivo organotípico de retina de rata, ${ }^{305}$ donde la microglía muestra actividad entre el primer y el sexto día de cultivo.

Varios estudios muestran que la respuesta de la microglía prevalece sobre la macrofágica en algunas enfermedades retinianas, ${ }^{339,} 340$ pero otros han descrito como la migración de los macrófagos tisulares hacia la retina predomina sobre la activación de la microglía. ${ }^{39}$ Por otra parte, también puede ser importante la acción conjunta de ambos tipos celulares durante los diferentes periodos del proceso patológico, como se ha observado en modelos experimentales de la neuritis autoinmune, ${ }^{341}$ donde la reacción macrofágica se lleva a cabo por parte de la microglía en las primeras fases, proliferando estas células, pero cuando la enfermedad inflamatoria presenta signos clínicos más severos, su número disminuye, siendo los macrófagos sanguíneos infiltrantes el principal efector de la respuesta inmune. ${ }^{341}$ 
Sabiendo ésto, representaría un gran paso determinar que tipo celular prevalece en los procesos patológicos retinianos, ya que los macrófagos infiltrantes tienen un poder destructivo mucho mayor que el de la microglía, ${ }^{40}$ pudiendo alterar profundamente la función retiniana, existiendo además, múltiples diferencias fenotípicas y fisiológicas entre ambos tipos celulares. $^{342}$ En comparación con otros tipos de macrófagos tisulares, la microglía está mucho más diferenciada, y el microambiente neuronal regula drásticamente su fenotipo,321, 343 manteniéndose como células relativamente quiescentes y no expresando muchos de los marcadores macrofágicos. ${ }^{73,321,343}$ Además, se conoce que la microglía del tejido nervioso se activa secundariamente a las señales proinflamatorias que se originan en otras regiones, mientras que, los macrófagos derivados del torrente sanguíneo reconocen y responden directamente a los estímulos relacionados con un daño, liberando potentes citoquinas proangiogénicas y proinflamatorias, como el $\mathrm{TNF} \alpha$, que por sí solo tiene la capacidad de activar a la microglía y a los astrocitos en el sistema nervioso central. ${ }^{344}$ Sin embargo, actualmente sigue sin estar claro el papel que pueden jugar dichos tipos celulares en las enfermedades retinianas, probablemente predominando la repuesta de uno $\mathrm{u}$ otro dependiendo de cada patología. En el caso de la VRP, podría proponerse una respuesta similar a la descrita para la neuritis autoinmune, actuando la microglía durante los cambios precoces debidos al DR y cobrando protagonismo los macrófagos infiltrantes cuando la patología se cronifica en forma de VRP. Si esto es así, la utilización de agentes terapéuticos, como los bloqueantes del TNF, se debería aplicar en las fases iniciales de la enfermedad, cuando todavía no hay signos clínicos de VRP. De aquí la importancia de identificar los pacientes de riesgo de entre toda la población que sufre un DR, como ha estudiado el Grupo de Retina del IOBA durante los últimos años..$^{6-8}$ 
Por otra parte, las modificaciones observadas en los explantes retinianos cultivados con PBMCs coinciden con los descritos en estudios previos realizados a partir de fragmentos retinianos humanos provenientes de retinectomías de pacientes con $\mathrm{VRP},{ }^{14,28-30}$ donde se ha descrito una degeneración de los OS e IS de los fotorreceptores, una notable desorganización de la estructura retiniana, una considerable pérdida de núcleos neuronales y una gliosis reactiva con un aumento en la expresión de la GFAP. Otros trabajos, realizados también a partir de fragmentos retinianos humanos, han revelado un aumento de los filamentos intermedios $\mathrm{GFAP}^{+}$a lo largo de la célula de Müller, 293, 345 estando, en estos casos, notablemente aumentada la expresión de la GFAP en comparación con los modelos previos de DR experimentales. ${ }^{17,31,132,294}$

Sin embargo, otra de las características propias de la VRP en el ser humano, que no se reproduce en estos modelos, es el crecimiento de membranas epirretinianas. Estas membranas son un tejido complejo, formado principalmente por células del EPR en proliferación, macrófagos, células gliales, fibroblastos, hialocitos y células ganglionares, 2,13, 17, 28, 30, 346, 347 pudiendo variar, a lo largo del proceso patológico, los tipos celulares presentes. ${ }^{347}$ Estas membranas se comportan como un elemento activo y contráctil en la VRP, jugando un papel importante en el proceso de la enfermedad, y atribuyéndoles la formación de pliegues retinianos, observados en algunos casos de VRP y que originan un DR traccional.

Al igual que en los resultados aquí presentados, tampoco se ha descrito la formación de membranas epirretinianas en otros cultivos de retina de cerdo, aunque se cultivara con el EPR o con parches de EPR-coroides. ${ }^{77,115,295}$ Como se ha descrito, parece necesaria una combinación de múltiples tipos celulares, algunos de ellos ausentes en estos modelos, a lo largo del tiempo y en un ambiente determinado, para que se originen. Así, en el caso del cultivo de retina bovina es necesario añadir células del EPR o fibroblastos para que se formen membranas contráctiles, con unas caractarísticas morfológicas y funcionales similares a las 
membranas epirretinianas. ${ }^{182}$ Sin embargo, la presencia de otros tipos celulares presuntamente implicados en su desarrollo, como son las células gliales y los macrófagos, no parecen suficientes para su formación en los experimentos aquí descritos. Estos hallazgos podrían restar importancia a la implicación de los macrófagos en la formación de estas membranas. Igualmente, no está claro el papel que puedan jugar las células gliales en su desarrollo, puesto que se ha considerado que todas las membranas retinianas se originan a partir de un componente glial, ${ }^{17}$ pero no se ha detectado la presencia de la GFAP en las membranas epirretinianas de algunos tipos de VRP. ${ }^{14}$ Además, en estos experimentos las células ganglionares degeneraron rápidamente, de modo que no contribuirían en su formación, y también cabe mencionar la ausencia de vítreo en este modelo de cultivo, careciendo de la presencia de hialocitos y del soporte que supone este tejido para las células que migran a la región vitreorretiniana y forman las membranas.

Por otra parte, en los modelos de DR en gato, se consideraría necesaria la reaplicación de la retina para la formación de las membranas epirretinianas. ${ }^{17}$ Así, en retinas desprendidas durante más de tres días, las células de Müller crecen únicamente por el espacio subretiniano, mientras que cuando la retina es reaplicada, los procesos de las células de Müller cesan su crecimiento por el espacio subretiniano y se extienden a lo largo de la superficie vítrea de la retina, asumiendo propiedades contráctiles, produciendo extensos pliegues y, eventualmente, el redesprendimiento de la retina, asemejándose por tanto, con las membranas epirretinianas observadas en la VRP. Igualmente, en los modelos de DR realizados en cerdo, aunque se produce una gran gliosis reactiva, no se desarrollan membranas epirretinianas, ${ }^{132,294}$ que si aparecen en el caso de procesos quirúrgicos complejos, como el transplante autólogo de un parche de EPR-coroides, donde la retina es reaplicada (Fernandez-Bueno y cols., en vías de publicación). Sin embargo, modelos de VRP en conejo y cerdo, han mostrado que no es necesaria la reaplicación de la retina para que se originen estas membranas tras un daño, 


\section{Discusián}

mientras se presenten algunos factores de crecimiento como el PRP o el PDGF.133, 141 No obstante, es necesario tener en cuenta que in vivo, más que el daño retiniano en sí mismo, son múltiples los factores que intervienen para dar lugar a los cambios que acontecen en la retina, como los componentes del suero sanguíneo o la secreción de factores por parte de las células retinianas y no retinianas que migran a la zona dañada, considerándose los principales responsables del aumento de los filamentos intermedios en las células gliales. ${ }^{348}$

\subsubsection{Cultivo de los explantes neurorretinianos con}

\section{monocitos CD14+}

En la evaluación inmunohistoquímica de los explantes cultivados con monocitos CD14 ${ }^{+}$ no se apreciaron cambios intrarretinianos significativos, ni modificaciones en la expresión de la GFAP ni en el espesor del tejido retiniano, en comparación con los controles. Estas modificaciones se consideran menores que las originadas en los cultivos con PBMCs, aunque los monocitos $\mathrm{CD}_{14} 4^{+}$utilizados se diferenciaron hacia macrófagos maduros y produjeron $\mathrm{TNF} \alpha$.

En los experimentos descritos, los monocitos CD14+ tras ser cultivados durante cuatro días, expresaron SWC9, alcanzando por tanto, un estado de madurez. Los monocitos porcinos no expresan espontáneamente el antígeno SWC9, que aparece solo cuando se diferencian hacia macrófagos maduros, siendo considerado como un antígeno selectivo. ${ }^{349}$ Los monocitos comienzan a expresar dicho antígeno a las veinticuatro horas de cultivo, alcanzando la máxima expresión a los cuatro días. ${ }^{288,350}$ El fenotipo de estos macrófagos SWC9+ $^{+}$se corresponde con el de los macrófagos obtenidos de pulmón y de bazo porcino, demostrando que la forma de diferenciación in vitro es similar a la que ocurre in vivo. ${ }^{289}$ 
Por otra parte, durante el cultivo se detectó un aumento en los niveles de TNF $\alpha$ en el medio de cultivo con monocitos $\mathrm{CD}_{14} 4^{+}$, alcanzando una concentración máxima de $13,7( \pm 3,0)$ $\mathrm{pg} / \mathrm{mL}$ a los cinco días, atribuyendo a estas células la secrección de dicha citoquina. En este modelo, es posible que los factores secretados por las células retinianas en degeneración se sumen a la presencia de suero en el medio de cultivo, lo que acelera la maduración de los monocitos hacia macrófagos, ${ }^{38}$ contribuyendo conjuntamente a la estimulación y a la activación de los monocitos CD14 ${ }^{+}$. Además, aunque los monocitos porcinos constituyen una población heterogénea con diferente capacidad de producción de $\mathrm{TNF} \alpha{ }^{275}$ tras su estimulación cerca del 70-80\% de la población monocitaria porcina expresa esta citoquina, encontrando solo un $5 \%$ de monocitos no estimulados. ${ }^{275}$

Los monocitos CD14+ se depositaron en el medio de cultivo en este experimento, en vez de sobre la retina como se hizo con los PBMCs, porque se pretendió discernir si los cambios en las células gliales eran originados por el contacto célula-célula con los macrófagos o si intervenía alguna de las múltiples citoquinas liberadas por éstos. Nuestros resultados sugieren que es necesario el contacto entre células para producir un incremento de las modificaciones retinianas, principalmente en la expresión de la GFAP por parte de las células gliales. No obstante, esta hipótesis no descarta la implicación del TNF $\alpha$ en dicha interacción, ya que puede presentarse integrado en la membrana celular, como forma transmembrana, llevando a cabo su acción tras el contacto entre células. Por otra parte, también puede barajarse la posibilidad de que los niveles de TNF $\alpha$ secretado por los monocitos $\mathrm{CD}_{14}{ }^{+}$en este experimento, no fueran lo suficientemente elevados como para sobreestimular la expresión de la GFAP en los explantes retinianos. 
No se puede descartar la presencia en el tejido retiniano de células potencialmente productoras de TNF $\alpha$, como la microglía ${ }^{305,} 351$ o los astrocitos, ${ }^{352,353}$ e incluso las propias células de Müller, como se ha observado en modelos de glaucoma. ${ }^{53,354}$ Sin embargo, en los cultivos control solo se encontraron niveles de esta citoquina durante el primer día, no siendo detectable mediante el método de ELISA utilizado, que tiene un nivel mínimo de detección de $3,7 \mathrm{pg} / \mathrm{mL}$, durante el resto del cultivo. Estos resultados son semejantes a los observados en el cultivo organotípico de retina de rata, dónde solo aparecieron niveles detectables de TNF $\alpha$ durante el primer día de cultivo, atribuyendo la secrección de esta citoquina a la microglía. ${ }^{305}$ Así pues, puede asumirse que los niveles de TNF $\alpha$ detectados durante el experimento con monocitos CD14 ${ }^{+}$, y que aparecen durante los nueve días de cultivo, son secretados por estas células.

\subsubsection{Cultivo de los explantes neurorretinianos con TNF $\alpha$}

Aunque son varias las citoquinas implicadas en la VRP, los hallazgos descritos por otros autores, al igual que los realizados por el Grupo de Retina del IOBA durante los últimos años, ${ }^{8,}$ 14 apuntan directamente hacia el TNF $\alpha$ como uno de los principales implicados en la patogenia de esta patología. Además, se sabe que en el sistema nervioso central el TNF $\alpha$ está implicado en la cronicidad de la respuesta inflamatoria, originando un daño tisular, así como en la desmielinización y en la degeneración axonal. ${ }^{51,52}$

De los experimentos planteados para determinar si el TNF $\alpha$ tiene un efecto sobre la expresión de la GFAP, se desprende que son necesarias concentraciones de al menos 100 pg/ mL de TNF $\alpha$ exógeno para estimular cambios retinianos asociados con los procesos de gliosis reactiva, durante un periodo de cultivo corto. Por ello, se utilizó dicha concentración en los 
experimentos posteriores, ya que de las dosis utilizadas es la mínima capaz de inducir cambios en las células gliales retinianas.

La evaluación inmuhistoquímica de los explantes cultivados con 100 pg/mL de TNF $\alpha$ durante tres, seis y nueve días, reveló un aumento progresivo en la expresión de la GFAP a lo largo de la célula de Müller, llegando sus extensiones celulares a atravesar la OLM, e invadir el área subretiniana, comenzando a originar membranas tisulares en esta zona. Por otra parte, se observó una reducción y finalmente una pérdida de la expresión de la CRALBP, una notable reducción en el número de núcleos $\mathrm{DAPI}^{+}$y una gran desorganización de la estructura retiniana, con la consiguiente pérdida de la compactación celular, que originó el aumento del espesor del tejido retiniano.

Los resultados observados permiten reconsiderar los efectos que el TNF $\alpha$ producido por los monocitos $\mathrm{CD} 14^{+}$puede ejercer sobre los cultivos retinianos, ya que concentraciones de 25 y 50 pg/mL de TNFa exógeno no originaron cambios en la expresión de la GFAP, siendo necesarias dosis de $100 \mathrm{pg} / \mathrm{mL}$ o superiores para inducirlos, y sabiendo que los niveles máximos detectados en el sobrenadante de los cultivos con monocitos CD14+ fueron de 13,7 $( \pm 3,0) \mathrm{pg} / \mathrm{mL}$. Por lo tanto, se necesitan concentraciones muy superiores a las secretadas por estos monocitos para originar cambios en las células gliales.

Igualmente, la importancia que pudieran tener otras células retinianas, principalmente la microglía, en la sobreestimulación de las células de Müller, también se podría replantear, al menos a través de la secrección de TNF $\alpha$, puesto que las concentraciones de esta citoquina, que originan cambios en el parénquima retiniano, son muy superiores a los niveles detectados en los controles del cultivo, y a los observados en estudios previos realizados en retinas de rata, en los que se atribuía la secreción de TNF $\alpha$ íntegramente a la microglía. ${ }^{305}$ 
Las modificaciones observadas en el parénquima retiniano al añadir TNF $\alpha$ exógeno son comparables con las producidas durante el cultivo con PBMCs, pudiendo atribuir a esta citoquina un papel principal en la interacción entre los macrófagos y las células de Müller, para el desarrollo de la gliosis reactiva. Sin embargo, durante el cultivo con PBMCs se produjo la invasión del área subretiniana por parte de múltiples prolongaciones de las células de Müller, originando formaciones tisulares en esta región, algo que solo comenzó a apreciarse a los nueve días de cultivo con TNF $\alpha$ exógeno. No obstante, las células macrofágicas utilizadas pudieron secretar potencialmente otras citoquinas implicadas en la VRP, como el TGF $\beta$, el PDGF, la IL1 $\alpha$, la IL1 $\beta$ y/o el MIF, pudiendo ser las responsables de estos cambios. 5, 9, 61, 236, 239, 242, 244 Por otra parte, también hay que tener en cuenta que el TNF $\alpha$ utilizado actuaría como sTNF $\alpha$, mientras que los macrófagos originados a partir de los PBMCs pudieron producir mTNF $\alpha$, ejerciendo su acción mediante el contacto célula-célula, además de liberar sTNF $\alpha$.

No ha sido el objetivo de este trabajo discernir que tipo de TNF $\alpha$ es el principal implicado en la interacción celular mencionada, ni que receptores están siendo estimulados, sabiendo de la extremada complejidad de acción que tiene esta citoquina, ya que dependiendo de los mecanismo moleculares desencadenados en sus receptores puede tener una acción neuroprotectora o neurodegenerativa. ${ }^{62,225-227}$ No obstante, hay evidencias de que el tipo de tejido y el ambiente celular son factores importantes para determinar el efecto de la acción del $\mathrm{TNF} \alpha,{ }^{217}$ e incluso que la actividad de esta citoquina depende no solo del tipo celular, sino también de las interacciones entre las células y de su estado fisiológico, ${ }^{354}$ por lo tanto, los complejos estudios requeridos para averiguar las vías de acción del TNF $\alpha$ en la VRP deberían realizarse directamente en seres humanos. 


\subsubsection{Cultivo de los explantes neurorretinianos con adalimumab y con $\mathrm{TNF} \alpha /$ adalimumab}

El adalimumab demostró actividad tanto en los cultivos control como cuando fue añadido con TNF $\alpha$ exógeno, originando un menor grado de gliosis reaccional y una mejor conservación del parénquima retiniano. La acción que este antagonista del TNF tiene directamente sobre los explantes en cultivo se puede atribuir al bloqueo del TNF $\alpha$ producido por las propias células de la retina, siendo también efectivo para bloquear el efecto sobreestimulador que el $\mathrm{TNF} \alpha$ exógeno ejerce sobre las células gliales. Estos resultados implicarían directamente al TNF $\alpha$ en el desarrollo de la gliosis reaccional observada en estos experimentos.

La concentración de adalimumab utilizada, $10 \mu \mathrm{g} / \mathrm{mL}$, fue inferior a las potencialmente tóxicas para el tejido retiniano tras inyección intravítrea, 0,5 mg/0,1 mL, ${ }^{273,274}$ y superior a la dosis efectiva capaz de neutralizar el $90 \%$ del sTNF $\alpha$, siendo ésta de $9 \mathrm{ng} / \mathrm{mL}$ para bloquear 3 ng/mL de sTNF ${ }^{266}$ Además la concentración utilizada en estos experimentos ha sido empleada eficazmente en cultivos celulares. ${ }^{278,279}$ De este modo, la dosis del antagonista utilizada no induciría un daño directo sobre la retina, y tras el bloqueo del TNF $\alpha$ exógeno añadido, $100 \mathrm{pg} / \mathrm{mL}$, seguiría existiendo una concentracción de adalimumab no unido que podría seguir actuando, como así se ha mostrado, al reducir también los cambios glióticos espontáneos a lo largo del cultivo con TNF $\alpha$ exógeno.

El mecanismo de acción del adalimumab se basa en la unión al TNF $\alpha$ impidiendo el contacto con los TNFRs de manera competitiva, y por tanto, bloqueando su actividad biológica. Por ello, fue necesario añadir conjuntamente el TNF $\alpha$ y el agente anti-TNF en el medio de cultivo, con la finalidad de bloquear dicha citoquina e impedir completamente la 
unión con los TNFRs del parénquima retiniano, ya que tras la unión con sus receptores, el adalimumab no es capaz de bloquear la acción biológica del TNF $\alpha$.

Aunque el adalimumab es un anticuerpo humanizado, las secuencias del TNF $\alpha$ humano y del porcino comparten múltiples características, como la longitud y la polaridad (Homo sapiens, http://genome.ucsc.edu/cgi-bin/pbGlobal?proteinID=P01375; y Sus scrofa, $\underline{\text { http: } / /}$ genome.ucsc.edu/cgi-bin/pbGlobal?proteinID=P23563). Estas similitudes explicarían la eficacia del adalimumab en el bloqueo del TNF $\alpha$ porcino, lo que no ocurre en el caso del TNF $\alpha$ murino. ${ }^{266}$

Desde hace más de treinta años, se considera conveniente la inhibición de la hipertrofia de las células de Müller, ${ }^{17,}{ }^{32-34}$ sin embargo, todavía no se ha conseguido reducir satisfactoriamente la gliosis reactiva que estas células originan en el tejido retiniano. Se sabe que en el DR las células de Müller están afectadas, originando su hipertrofia, su hiperplasia y su crecimiento por el espacio subretiniano y epirretiniano. Sin embargo, los factores moleculares que controlan estos cambios todavía no están adecuadamente documentados. Las células de Müller, al igual que los fotorreceptores, reaccionan rápidamente tras el DR, mostrando cambios en su remodelación celular, incluyendo un aumento en la expresión de la GFAP y de la vimentina, y la reducción de la CRALBP, de la anhidrasa carbónica y de la glutamina sintetasa. ${ }^{284}$ Realmente, no está claro si estos mecanismos son neuroprotectores y/ o vasoprotectores, si tienen unos efectos adversos para las células retinianas o si, incluso, podrían argumentarse ambas teorías. ${ }^{355}$ Lo que es cierto, es que las células gliales reactivas pueden liberar múltiples citoquinas y especies reactivas de oxígeno, que se difunden a las regiones adyacentes y activan las vías apoptóticas, originando la pérdida de las neuronas que sobrevivieron al daño inicial. ${ }^{356-358}$ Además, tanto la hipertrofia de las células de Müller como su crecimiento por las superficies retinianas tienen una gran importancia práctica, ya que el 
crecimiento por el espacio subretiniano inhibe la regeneración de los OS de los fotorreceptores, ${ }^{359}$ y el crecimiento por la superficie vítrea puede contribuir a la contracción de la retina, lo que conlleva a la pérdida de la visión. ${ }^{359,} 360$ Estos cambios de las células de Müller no pueden ser considerados como acciones beneficiosas para la retina, ya que realmente estas células están alteradas durante el remodelado tisular, lo que tiene serias consecuencias para la fisiología retiniana. ${ }^{31}$

En los últimos años, se han probado numerosas sustancias para intentar inhibir la proliferación celular, y la formación y la contracción de las membranas retinianas en modelos in vivo e in vitro, como ya se ha mencionado. Durante este tiempo, algunas demostraron ser eficaces, sin embargo, muchas de ellas originaron graves efectos secundarios, y solo unas pocas llegaron a ser probadas en ensayos clínicos, pero finalmente no tuvieron un éxito manifiesto. $^{2,5}$ En este sentido, hay varios trabajos experimentales que han estudiado la proliferación de las células de Müller tras un daño retiniano, así como la utilización de sustancias capaces de bloquearla, ${ }^{361-367}$ no obstante, los estudios encaminados a reducir la hipertrofia de las células gliales son pocos..$^{33,34,364}$

Eibl y cols. (2007) ${ }^{364}$ describieron la utilización de alquilfosfocolinas para reducir la proliferación de las células de Müller tras el DR experimental en conejo, pero no resultaron eficaces en la reducción de la expresión de la vimentina, proteína implicada en la hipertrofia de las células de Müller.

Tura y cols. (2009) ${ }^{33}$ mostraron la eficacia del H-1152P para reducir la hipertrofia de las células gliales, en el cultivo organotípico de retina de ratón y tras inyección intravítrea previamente al daño del nervio óptico. Esta molécula es un inhibidor de la ROCK (RhOassoCiated protein Kinase), proteína que regula la organización del citoesqueleto de actina y sus eventos dinámicos, como la contracción, la adhesión, la motilidad, la progresión del ciclo celular y la expresión génica, en varios tipos celulares. ${ }^{368}$ Dicha sustancia tiene un efecto 


\section{Discusión}

neuroprotector sobre las células retinianas, particularmente sobre las células ganglionares, asociado a una disminución en la reactividad de los astrocitos, de las células de Müller y de la microglía. Sin embargo, todavía no está claro su mecanismo de acción, pudiendo atribuirse a la inhibición de la ROCK directamente en las neuronas retinianas, asociándose con la disminución de la reactividad de las células gliales; a la inhibición de la excesiva gliosis reactiva, asociándose con una protección neuronal; o a una acción simultánea tanto sobre las neuronas retinianas como sobre las células gliales. Por otra parte, aunque esta sustancia es capaz de disminuir la expresión de la GFAP, su efecto también se asocia con una reducción en los niveles de once citoquinas secretadas por las células retinianas, siendo mencionable la reducción del TNFa y de su receptor TNFR1, sin embargo, también disminuye los niveles de citoquinas antiinflamatorias, como la IL5 e IL13. Por último, aunque el H-1152P ha sido utilizado en múltiples estudios experimentales, y no solo a nivel ocular, no está aprobado por la FDA para su uso clínico.

Lewis y cols. (2009) ${ }^{34}$ describieron la utilidad del Palomid 529 (Paloma Pharmaceuticals, MA, EE.UU.) para reducir la proliferación y el crecimiento de las células gliales, y la muerte de los fotorreceptores, tras el DR experimental en conejo. Esta molécula sintética es un inhibidor de la vía Akt/mTOR, implicada en el metabolismo, en el crecimiento, en la supervivencia, en la apoptosis y en la progresión del ciclo celular, ${ }^{369}$ sugiriendo que dicha vía estaría activa tras el DR. ${ }^{34}$ Sin embargo, no se conoce exactamente su mecanismo de acción en la retina, no se tiene la certeza de que actúe directamente sobre las células de Müller, ya que podría hacerlo a través de la acción que tiene sobre las células del EPR, ${ }^{370} \mathrm{e}$ igualmente ocurre con su acción sobre los fotorreceptores. Los hallazgos están basados en el análisis de la expresión de la vimentina, proteína no evaluada en este trabajo, sin embargo, como bien mencionan Eibl y cols., ${ }^{364}$ una posible estrategia para controlar la hipertrofia de las células de Müller pasaría por inhibir la sobreexpresión de ambos filamentos intermedios, la 
GFAP y la vimentina. El Palomid 529 también parece tener un efecto sobre la microglía/ macrófagos, reduciendo su respuesta, pero tampoco se conoce si esta sustancia actúa directamente sobre las células inmunes o indirectamente a través de otros tipos celulares como las células de Müller o del EPR. El Palomid 529 tampoco está aceptado por la FDA para uso clínico, pero los autores consideran que podría utilizarse para tratar las enfermedades proliferativas asociadas con la cirugía del DR y la consiguiente muerte de los fotorreceptores.

Finalmente, del trabajo aquí presentado se desprende que la utilización de agentes biológicos bloqueantes del TNF podría abrir una nueva vía de actuación en la reducción de los cambios gliales que sufre la retina tras un DR, actuando directamente sobre su diana terapeútica, el TNF $\alpha$, que estaría implicado en las interacciones entre los macrófagos y las células de Müller, originando su hipertrofia. El bloqueo del TNF $\alpha$ permitiría reducir algunos de los cambios fibróticos que inducen el desprendimiento traccional de la retina, tras su reaplicación quirúrgica, con la consiguiente pérdida de la función visual, en los pacientes con VRP.

A pesar de que son necesarios estudios complementarios encaminados a probar la eficacia y la seguridad de los agentes antagonistas del TNF en modelos animales, y posteriormente en los pertinentes ensayos clínicos, los hallazgos presentados en este trabajo representan una aproximación importante hacia la aplicación clínica de estos agentes como coadyuvantes en el tratamiento de la VRP, habiendo demostrado ser eficaces en el bloqueo del TNF $\alpha$ tras inyección intravítrea, ${ }^{371}$ y estando aprobados por la FDA para su uso clínico. 


\subsection{Continuación de la línea de investigación}

Con la continuación del proyecto se intentarán resolver los problemas planteados en este trabajo, e igualmente se evaluará la potencial aplicación que los agentes bloqueantes del TNF pudieran tener en el tratamiento de la VRP.

Entre las acciones a llevar a cabo para alcanzar este fin, se pueden sugerir:

- Ampliar las técnicas histológicas e inmunohistoquímicas, para poder evaluar las modificaciones de las neuronas retinianas y de la microglía, así como analizar la proliferación y la muerte celular, durante las diferentes condiciones de cultivo planteadas.

- Aplicar un programa de análisis de imagen que permita evaluar objetiva y cuantitativamente los cambios celulares producidos durante los cultivos.

- Evaluar la eficacia de otros agentes antagonistas del TNF, pudiendo tener importancia el bloqueo conjunto del TNF $\alpha$ y del TNF $\beta$ (o LTA), como apuntan las actuales líneas de investigación desarrolladas por el Grupo de Retina del IOBA. Para ello, sería necesario estudiar la eficacia del etanercept y del infliximab, ambos bloqueantes potenciales del TNF $\beta$.

- Utilizar la técnica de cultivo organotípico descrita con muestras de neurorretina humana, permitiendo determinar in vitro el efecto que el TNF $\alpha$ exógeno y los agentes antagonistas del TNF ejercen sobre el tejido humano.

- Evaluar la eficacia de los agentes bloqueantes del TNF en modelos animales de DR y de VRP, lo que además permitiría la obtención de importantes datos relacionados con su tolerancia, vida media y concentraciones efectivas tras la administración intravítrea.

- Por último, si tras estos ensayos los resultados siguen siendo satisfactorios, y previamente al planteamiento de un ensayo clínico, se podría evaluar la incidencia y la evolución de la VRP 
en pacientes que sufran un DR y que estén siendo tratados con agentes anti-TNF debido a otras patologías. 



\section{Candusianes}



De acuerdo con los objetivos planteados en este trabajo y como consecuencia de los resultados obtenidos y de su discusión, se ha llegado a las siguientes conclusiones:

1. El modelo de cultivo organotípico de neurorretina porcina permite la evaluación de algunas de las modificaciones celulares producidas tras el desprendimiento de retina, facilitando el estudio de las interacciones con otros tipos celulares no retinianos y/o con las citoquinas secretadas por estas células.

2. Los macrófagos están implicados en las modificaciones que experimentan las células de Müller, porque su adición al cultivo de las neurorretinas origina un aumento en la hipertrofia reactiva.

3. El TNF $\alpha$ juega un papel muy importante en la mediación entre los macrófagos y las células de Müller, porque su adición al cultivo de las neurorretinas origina unas modificaciones similares a las producidas por los macrófagos.

4. Se puede intentar abordar la vitreorretinopatía proliferante con agentes antagonistas del TNF, como el adalimumab, capaz de bloquear las modificaciones espontáneas y las originadas por el TNF $\alpha$ exógeno en las neurorretinas cultivadas, aunque son necesarios más estudios antes de plantear un ensayo clínico piloto. 



\section{Bibliagrafía}



1. Machemer R, Aaberg TM, Freeman HM, Irvine AR, Lean JS, Michels RM. An updated classification of retinal detachment with proliferative vitreoretinopathy. Am J Ophthalmol 1991;112:159-165.

2. Pastor JC, de la Rua ER, Martin F. Proliferative vitreoretinopathy: risk factors and pathobiology. Prog Retin Eye Res 2002;21:127-144.

3. de la Rua ER, Pastor JC, Fernandez I, et al. Non-complicated retinal detachment management: variations in 4 years. Retina 1 project; report $1 . \mathrm{Br} J$ Ophthalmol 2008;92:523-525.

4. Patel NN, Bunce $\mathrm{C}$, Asaria $\mathrm{RH}$, Charteris DG. Resources involved in managing retinal detachment complicated by proliferative vitreoretinopathy. Retina 2004;24:883-887.

5. $\quad$ Pastor JC. Proliferative vitreoretinopathy: an overview. Surv Ophthalmol 1998;43:3-18.

6. Rojas J, Fernandez I, Pastor JC, et al. Development of predictive models of proliferative vitreoretinopathy based on genetic variables: the Retina 4 project. Invest Ophthalmol Vis Sci 2009;50:2384-2390.

7. Sanabria Ruiz-Colmenares MR, Pastor Jimeno JC, Garrote Adrados JA, Telleria Orriols JJ, Yugueros Fernandez MI. Cytokine gene polymorphisms in retinal detachment patients with and without proliferative vitreoretinopathy: a preliminary study. Acta Ophthalmol Scand 2006;84:309-313.

8. Rojas J, Fernandez I, Pastor JC, et al. A strong genetic association between the tumor necrosis factor locus and proliferative vitreoretinopathy: the retina 4 project. Ophthalmology 2010;117:2417-2423 e2411-2412.

9. Kon $\mathrm{CH}$, Occleston NL, Aylward GW, Khaw PT. Expression of vitreous cytokines in proliferative vitreoretinopathy: a prospective study. Invest Ophthalmol Vis Sci 1999;40:705-712.

10. El-Ghrably IA, Dua HS, Orr GM, Fischer D, Tighe PJ. Detection of cytokine mRNA production in infiltrating cells in proliferative vitreoretinopathy using reverse transcription polymerase chain reaction. Br J Ophthalmol 1999;83:1296-1299.

11. Charteris DG, Hiscott P, Robey HL, Gregor ZJ, Lightman SL, Grierson I. Inflammatory cells in proliferative vitreoretinopathy subretinal membranes. Ophthalmology 1993;100:43-46.

12. Hisatomi T, Sakamoto $\mathrm{T}$, Sonoda $\mathrm{KH}$, et al. Clearance of apoptotic photoreceptors: elimination of apoptotic debris into the subretinal space and macrophage-mediated phagocytosis via phosphatidylserine receptor and integrin alphavbeta3. Am J Pathol 2003;162:1869-1879.

13. Jerdan JA, Pepose JS, Michels RG, et al. Proliferative vitreoretinopathy membranes. An immunohistochemical study. Ophthalmology 1989;96:801-810.

14. Pastor JC, Mendez MC, de la Fuente MA, et al. Intraretinal immunohistochemistry findings in proliferative vitreoretinopathy with retinal shortening. Ophthalmic Res 2006;38:193-200.

15. Charteris DG. Proliferative vitreoretinopathy: pathobiology, surgical management, and adjunctive treatment. Br J Ophthalmol 1995;79:953-960.

16. Baudouin C, Hofman P, Brignole F, Bayle J, Loubiere R, Gastaud P. Immunocytology of cellular components in vitreous and subretinal fluid from patients with proliferative vitreoretinopathy. Ophthalmologica 1991;203:38-46. 


\section{Bibliagrafia}

17. Fisher SK, Lewis GP. Muller cell and neuronal remodeling in retinal detachment and reattachment and their potential consequences for visual recovery: a review and reconsideration of recent data. Vision Res 2003;43:887-897.

18. Reichenbach A, Stolzenburg JU, Eberhardt W, Chao TI, Dettmer D, Hertz L. What do retinal muller (glial) cells do for their neuronal 'small siblings'? J Chem Neuroanat 1993;6:201-213.

19. Newman E, Reichenbach A. The Muller cell: a functional element of the retina. Trends Neurosci 1996;19:307-312.

20. Mano T, Puro DG. Phagocytosis by human retinal glial cells in culture. Invest Ophthalmol Vis Sci 1990;31:1047-1055.

21. Francke M, Makarov F, Kacza J, et al. Retinal pigment epithelium melanin granules are phagocytozed by Muller glial cells in experimental retinal detachment. J Neurocytol 2001;30:131-136.

22. Caspi RR, Roberge FG. Glial cells as suppressor cells: characterization of the inhibitory function. J Autoimmun 1989;2:709-722.

23. Roberge FG, Caspi RR, Chan CC, Nussenblatt RB. Inhibition of T lymphocyte proliferation by retinal glial Muller cells: reversal of inhibition by glucocorticoids. J Autoimmun 1991;4:307-314.

24. Bignami A, Dahl D. The radial glia of Muller in the rat retina and their response to injury. An immunofluorescence study with antibodies to the glial fibrillary acidic (GFA) protein. Exp Eye Res 1979;28:63-69.

25. Eisenfeld AJ, Bunt-Milam AH, Sarthy PV. Muller cell expression of glial fibrillary acidic protein after genetic and experimental photoreceptor degeneration in the rat retina. Invest Ophthalmol Vis Sci 1984;25:1321-1328.

26. Bringmann A, Reichenbach A. Role of Muller cells in retinal degenerations. Front Biosci 2001;6:E72-92.

27. Bringmann A, Pannicke T, Grosche J, et al. Muller cells in the healthy and diseased retina. Prog Retin Eye Res 2006;25:397-424.

28. Charteris DG, Downie J, Aylward GW, Sethi C, Luthert P. Intraretinal and periretinal pathology in anterior proliferative vitreoretinopathy. Graefes Arch Clin Exp Ophthalmol 2007;245:93-100.

29. Wickham L, Charteris DG. Glial cell changes of the human retina in proliferative vitreoretinopathy. Dev Ophthalmol 2009;44:37-45.

30. Sethi CS, Lewis GP, Fisher SK, et al. Glial remodeling and neural plasticity in human retinal detachment with proliferative vitreoretinopathy. Invest Ophthalmol Vis Sci 2005;46:329-342.

31. Fisher SK, Lewis GP, Linberg KA, Verardo MR. Cellular remodeling in mammalian retina: results from studies of experimental retinal detachment. Prog Retin Eye Res 2005;24:395-431.

32. Van Horn DL, Aaberg TM, Machemer R, Fenzl R. Glial cell proliferation in human retinal detachment with massive periretinal proliferation. Am J Ophthalmol 1977;84:383-393.

33. Tura A, Schuettauf F, Monnier PP, Bartz-Schmidt KU, Henke-Fahle S. Efficacy of Rhokinase inhibition in promoting cell survival and reducing reactive gliosis in the rodent retina. Invest Ophthalmol Vis Sci 2009;50:452-461. 
34. Lewis GP, Chapin EA, Byun J, Luna G, Sherris D, Fisher SK. Muller cell reactivity and photoreceptor cell death are reduced after experimental retinal detachment using an inhibitor of the Akt/mTOR pathway. Invest Ophthalmol Vis Sci 2009;50:4429-4435.

35. Celada A, Nathan C. Macrophage activation revisited. Immunol Today 1994;15:100-102.

36. Forrester JV, Dick AD, McMenamin PG, Lee WR. The Eye: basic sciences in practice, Chapter 7: Immunology. 2nd ed. WB Saunders Company Ltd, London; 1996:265-318.

37. Yang P, de Vos AF, Kijlstra A. Macrophages in the retina of normal Lewis rats and their dynamics after injection of lipopolysaccharide. Invest Ophthalmol Vis Sci 1996;37:77-85.

38. Osusky R, Ryan SJ. Retinal pigment epithelial cell proliferation: potentiation by monocytes and serum. Graefes Arch Clin Exp Ophthalmol 1996;234 Suppl 1:S76-82.

39. Caicedo A, Espinosa-Heidmann DG, Pina Y, Hernandez EP, Cousins SW. Blood-derived macrophages infiltrate the retina and activate Muller glial cells under experimental choroidal neovascularization. Exp Eye Res 2005;81:38-47.

40. Gordon S. The macrophage. Bioessays 1995;17:977-986.

41. Wiedemann P. Growth factors in retinal diseases: proliferative vitreoretinopathy, proliferative diabetic retinopathy, and retinal degeneration. Surv Ophthalmol 1992;36:373-384.

42. Zacks DN, Han Y, Zeng Y, Swaroop A. Activation of signaling pathways and stressresponse genes in an experimental model of retinal detachment. Invest Ophthalmol Vis Sci 2006;47:1691-1695.

43. Hiscott P. Macrophages in the pathobiology of epiretinal membranes: multifunctional cells for a multistage process. Br J Ophthalmol 1993;77:686-687.

44. Kirchhof B, Sorgente N. Pathogenesis of proliferative vitreoretinopathy. Modulation of retinal pigment epithelial cell functions by vitreous and macrophages. Dev Ophthalmol 1989;16:1-53.

45. Martin F, Pastor JC, De La Rua ER, et al. Proliferative vitreoretinopathy: cytologic findings in vitreous samples. Ophthalmic Res 2003;35:232-238.

46. Osusky R, Malik P, Aurora Y, Ryan SJ. Monocyte-macrophage differentiation induced by coculture of retinal pigment epithelium cells with monocytes. Ophthalmic Res 1997;29:124-129.

47. Toti P, Greco G, Catella AM. Morphological and pathogenetic aspects of proliferative vitreoretinopathy. A histological and immunohistochemical study. Doc Ophthalmol 1994;88:105-112.

48. Canataroglu H, Varinli I, Ozcan AA, Canataroglu A, Doran F, Varinli S. Interleukin (IL)-6, interleukin (IL)-8 levels and cellular composition of the vitreous humor in proliferative diabetic retinopathy, proliferative vitreoretinopathy, and traumatic proliferative vitreoretinopathy. Ocul Immunol Inflamm 2005;13:375-381.

49. Lin ML, Li YP, Li ZR, Lin JX, Zhou XL, Liang D. Macrophages acquire fibroblast characteristics in a rat model of proliferative vitreoretinopathy. Ophthalmic Res 2011;45:180-190.

50. MacEwan DJ. TNF ligands and receptors--a matter of life and death. $\mathrm{Br} J$ Pharmacol 2002;135:855-875. 


\section{Bibliagrafia}

51. Rothwell NJ, Hopkins SJ. Cytokines and the nervous system II: Actions and mechanisms of action. Trends Neurosci 1995;18:130-136.

52. Keffer J, Probert L, Cazlaris $\mathrm{H}$, et al. Transgenic mice expressing human tumour necrosis factor: a predictive genetic model of arthritis. EMBO J 1991;10:4025-4031.

53. Tezel G, Li LY, Patil RV, Wax MB. TNF-alpha and TNF-alpha receptor-1 in the retina of normal and glaucomatous eyes. Invest Ophthalmol Vis Sci 2001;42:1787-1794.

54. Nakazawa T, Nakazawa C, Matsubara A, et al. Tumor necrosis factor-alpha mediates oligodendrocyte death and delayed retinal ganglion cell loss in a mouse model of glaucoma. J Neurosci 2006;26:12633-12641.

55. de Kozak Y, Naud MC, Bellot J, Faure JP, Hicks D. Differential tumor necrosis factor expression by resident retinal cells from experimental uveitis-susceptible and -resistant rat strains. J Neuroimmunol 1994;55:1-9.

56. de Vos AF, van Haren MA, Verhagen C, Hoekzema R, Kijlstra A. Kinetics of intraocular tumor necrosis factor and interleukin- 6 in endotoxin-induced uveitis in the rat. Invest Ophthalmol Vis Sci 1994;35:1100-1106.

57. Markomichelakis NN, Theodossiadis PG, Pantelia E, Papaefthimiou S, Theodossiadis GP, Sfikakis PP. Infliximab for chronic cystoid macular edema associated with uveitis. Am J Ophthalmol 2004;138:648-650.

58. Nakamura S, Yamakawa T, Sugita M, et al. The role of tumor necrosis factor-alpha in the induction of experimental autoimmune uveoretinitis in mice. Invest Ophthalmol Vis Sci 1994;35:3884-3889.

59. de Kozak Y, Cotinet A, Goureau O, Hicks D, Thillaye-Goldenberg B. Tumor necrosis factor and nitric oxide production by resident retinal glial cells from rats presenting hereditary retinal degeneration. Ocul Immunol Inflamm 1997;5:85-94.

60. Armstrong D, Augustin AJ, Spengler R, et al. Detection of vascular endothelial growth factor and tumor necrosis factor alpha in epiretinal membranes of proliferative diabetic retinopathy, proliferative vitreoretinopathy and macular pucker. Ophthalmologica 1998;212:410-414.

61. Limb GA, Alam A, Earley O, Green W, Chignell AH, Dumonde DC. Distribution of cytokine proteins within epiretinal membranes in proliferative vitreoretinopathy. Curr Eye Res 1994;13:791-798.

62. Fontaine V, Mohand-Said S, Hanoteau N, Fuchs C, Pfizenmaier K, Eisel U. Neurodegenerative and neuroprotective effects of tumor Necrosis factor (TNF) in retinal ischemia: opposite roles of TNF receptor 1 and TNF receptor 2. $J$ Neurosci 2002;22:RC216.

63. Reiff A, Takei S, Sadeghi S, et al. Etanercept therapy in children with treatment-resistant uveitis. Arthritis Rheum 2001;44:1411-1415.

64. Sfikakis PP, Theodossiadis PG, Katsiari CG, Kaklamanis P, Markomichelakis NN. Effect of infliximab on sight-threatening panuveitis in Behcet's disease. Lancet 2001;358:295-296.

65. Tsilimbaris MK, Panagiotoglou TD, Charisis SK, Anastasakis A, Krikonis TS, Christodoulakis E. The use of intravitreal etanercept in diabetic macular oedema. Semin Ophthalmol 2007;22:75-79. 
66. Theodossiadis PG, Liarakos VS, Sfikakis PP, et al. Intravitreal administration of the antiTNF monoclonal antibody infliximab in the rabbit. Graefes Arch Clin Exp Ophthalmol 2009;247:273-281.

67. Arias L, Caminal JM, Badia MB, Rubio MJ, Catala J, Pujol O. Intravitreal infliximab in patients with macular degeneration who are nonresponders to antivascular endothelial growth factor therapy. Retina 2010;30:1601-1608.

68. Farvardin $\mathrm{M}$, Afarid $\mathrm{M}$, Mehryar $\mathrm{M}$, Hosseini $\mathrm{H}$. Intravitreal infliximab for the treatment of sight-threatening chronic noninfectious uveitis. Retina 2010;30:1530-1535.

69. Wu L, Hernandez-Bogantes E, Roca JA, Arevalo JF, Barraza K, Lasave AF. Intravitreal tumor necrosis factor inhibitors in the treatment of refractory diabetic macular edema: a pilot study from the Pan-American Collaborative Retina Study Group. Retina 2011;31:298-303.

70. Androudi S, Tsironi E, Kalogeropoulos C, Theodoridou A, Brazitikos P. Intravitreal adalimumab for refractory uveitis-related macular edema. Ophthalmology 2010;117:1612-1616.

71. Jap A, Chee SP. Immunosuppressive therapy for ocular diseases. Curr Opin Ophthalmol 2008;19:535-540.

72. Cuff CA, Berman JW, Brosnan CF. Interleukin-1beta-induced expression of monocyte chemotactic protein-1 in the rabbit retina: an in situ and immunohistochemical study. Glia 2000;30:279-289.

73. Dick $A D$, Carter $D$, Robertson $M$, et al. Control of myeloid activity during retinal inflammation. J Leukoc Biol 2003;74:161-166.

74. Nishijima K, Kiryu J, Tsujikawa A, et al. Platelets adhering to the vascular wall mediate postischemic leukocyte-endothelial cell interactions in retinal microcirculation. Invest Ophthalmol Vis Sci 2004;45:977-984.

75. Takanohashi A, Yabe T, Schwartz JP. Pigment epithelium-derived factor induces the production of chemokines by rat microglia. Glia 2005;51:266-278.

76. Agrawal RN, He S, Spee C, Cui JZ, Ryan SJ, Hinton DR. In vivo models of proliferative vitreoretinopathy. Nat Protoc 2007;2:67-77.

77. Winkler J, Hagelstein S, Rohde M, Laqua H. Cellular and cytoskeletal dynamics within organ cultures of porcine neuroretina. Exp Eye Res 2002;74:777-788.

78. Weller M, Wiedemann P, Heimann K. Proliferative vitreoretinopathy--is it anything more than wound healing at the wrong place? Int Ophthalmol 1990;14:105-117.

79. Tano Y, Chandler D, Machemer R. Treatment of intraocular proliferation with intravitreal injection of triamcinolone acetonide. Am J Ophthalmol 1980;90:810-816.

80. Koerner F, Merz A, Gloor B, Wagner E. Postoperative retinal fibrosis--a controlled clinical study of systemic steroid therapy. Graefes Arch Clin Exp Ophthalmol 1982;219:268-271.

81. Garcia A, Hernando MT, Manzanas L, Pastor JC. Tratamiento profilactico de la vitreoretinopatia proliferante. Arch Soc Esp Oftalmol 1991;60:315-322.

82. Cheema RA, Peyman GA, Fang T, Jones A, Lukaris AD, Lim K. Triamcinolone acetonide as an adjuvant in the surgical treatment of retinal detachment with proliferative vitreoretinopathy. Ophthalmic Surg Lasers Imaging 2007;38:365-370. 


\section{Bibliagrafia}

83. Blumenkranz M, Hernandez E, Ophir A, Norton EW. 5-fluorouracil: new applications in complicated retinal detachment for an established antimetabolite. Ophthalmology 1984;91:122-130.

84. Berman DH, Gombos GM. Proliferative vitreoretinopathy: does oral low-dose colchicine have an inhibitory effect? A controlled study in humans. Ophthalmic Surg 1989;20:268-272.

85. Wiedemann P, Leinung C, Hilgers RD, Heimann K. Daunomycin and silicone oil for the treatment of proliferative vitreoretinopathy. Graefes Arch Clin Exp Ophthalmol 1991;229:150-152.

86. Mietz H, Walshe R, Wiedemann P, Heimann K, Green WR. Histopathologic study of epiretinal proliferations after vitrectomy with daunomycin and silicone oil. Retina 1994;14:425-429.

87. Wiedemann P, Evans PY, Wiedemann R, Meyer-Schwickerath R, Heimann K. A fluorescein angiographic study on patients with proliferative vitreoretinopathy treated by vitrectomy and intraocular daunomycin. Int Ophthalmol 1989;13:211-216.

88. Charteris DG, Aylward GW, Wong D, Groenewald C, Asaria RH, Bunce C. A randomized controlled trial of combined 5-fluorouracil and low-molecular-weight heparin in management of established proliferative vitreoretinopathy. Ophthalmology 2004;111:2240-2245.

89. Wickham L, Sethi CS, Lewis GP, Fisher SK, McLeod DC, Charteris DG. Glial and neural response in short-term human retinal detachment. Arch Ophthalmol 2006;124:1779-1782.

90. Johnson RN, Blankenship G. A prospective, randomized, clinical trial of heparin therapy for postoperative intraocular fibrin. Ophthalmology 1988;95:312-317.

91. Iverson DA, Katsura H, Hartzer MK, Blumenkranz MS. Inhibition of intraocular fibrin formation following infusion of low-molecular-weight heparin during vitrectomy. Arch Ophthalmol 1991;109:405-409.

92. Asaria $\mathrm{RH}$, Kon $\mathrm{CH}$, Bunce $\mathrm{C}$, et al. Adjuvant 5-fluorouracil and heparin prevents proliferative vitreoretinopathy : Results from a randomized, double-blind, controlled clinical trial. Ophthalmology 2001;108:1179-1183.

93. Wickham L, Bunce C, Wong D, McGurn D, Charteris DG. Randomized controlled trial of combined 5-Fluorouracil and low-molecular-weight heparin in the management of unselected rhegmatogenous retinal detachments undergoing primary vitrectomy. Ophthalmology 2007;114:698-704.

94. Kuriyama S, Ohuchi T, Yoshimura N, Honda Y, Hiraoka M, Abe M. Evaluation of radiation therapy for experimental proliferative vitreoretinopathy in rabbits. Graefes Arch Clin Exp Ophthalmol 1990;228:552-555.

95. Binder S, Bonnet M, Velikay M, et al. Radiation therapy in proliferative vitreoretinopathy. A prospective randomized study. Graefes Arch Clin Exp Ophthalmol 1994;232:211-214.

96. Lei H, Velez $\mathrm{G}$, Cui J, et al. N-acetylcysteine suppresses retinal detachment in an experimental model of proliferative vitreoretinopathy. Am J Pathol 2010;177:132-140.

97. Hart PH, Vitti GF, Burgess DR, Whitty GA, Piccoli DS, Hamilton JA. Potential antiinflammatory effects of interleukin 4: suppression of human monocyte tumor necrosis factor alpha, interleukin 1, and prostaglandin E2. Proc Natl Acad Sci $U S A$ 1989;86:3803-3807. 
98. Nomoto A, Mutoh S, Hagihara H, Yamaguchi I. Smooth muscle cell migration induced by inflammatory cell products and its inhibition by a potent calcium antagonist, nilvadipine. Atherosclerosis 1988;72:213-219.

99. Daniels SA, Coonley KG, Yoshizumi MO. Taxol treatment of experimental proliferative vitreoretinopathy. Graefes Arch Clin Exp Ophthalmol 1990;228:513-516.

100. Ohuchi T, Kuriyama S, Yoshimura N, Honda Y, Hiraoka M, Abe M. Suppression of human retinal pigment epithelial cell proliferation by hyperthermia. Arch Ophthalmol 1990;108:873-875.

101. Oleszak E. Inhibition of mitogenic activity of PDGF, EGF, and FGF by interferon-gamma. Exp Cell Res 1988;179:575-580.

102. Kuratsu J, Ushio Y. Antiproliferative effect of trapidil, a platelet-derived growth factor antagonist, on a glioma cell line in vitro. J Neurosurg 1990;73:436-440.

103. Yang $\mathrm{CH}$, Huang TF, Liu KR, Chen MS, Hung PT. Inhibition of retinal pigment epithelial cellinduced tractional retinal detachment by disintegrins, a group of Arg-Gly-Asp-containing peptides from viper venom. Invest Ophthalmol Vis Sci 1996;37:843-854.

104. Maurice D. Review: practical issues in intravitreal drug delivery. J Ocul Pharmacol Ther 2001;17:393-401.

105. Guidetti B, Azema J, Malet-Martino M, Martino R. Delivery systems for the treatment of proliferative vitreoretinopathy: materials, devices and colloidal carriers. Curr Drug Deliv 2008;5:7-19.

106. Steinhorst UH, Chen EP, Hatchell DL, et al. Aclacinomycin A in the treatment of experimental proliferative vitreoretinopathy. Efficacy and toxicity in the rabbit eye. Invest Ophthalmol Vis Sci 1993;34:1753-1760.

107. Steinhorst UH, Chen EP, Machemer R, Hatchell DL. N,N-dimethyladriamycin for treatment of experimental proliferative vitreoretinopathy: efficacy and toxicity on the rabbit retina. Exp Eye Res 1993;56:489-495.

108. Barcia E, Herrero-Vanrell R, Diez A, Alvarez-Santiago C, Lopez I, Calonge M. Downregulation of endotoxin-induced uveitis by intravitreal injection of polylactic-glycolic acid (PLGA) microspheres loaded with dexamethasone. Exp Eye Res 2009;89:238-245.

109. Martinez-Sancho C, Herrero-Vanrell R, Negro S. Study of gamma-irradiation effects on aciclovir poly(D,L-lactic-co-glycolic) acid microspheres for intravitreal administration. $J$ Control Release 2004;99:41-52.

110. Rincon AC, Molina-Martinez IT, de Las Heras B, et al. Biocompatibility of elastin-like polymer poly(VPAVG) microparticles: in vitro and in vivo studies. J Biomed Mater Res A 2006;78:343-351.

111. Araiz JJ, Refojo MF, Arroyo MH, Leong FL, Albert DM, Tolentino FI. Antiproliferative effect of retinoic acid in intravitreous silicone oil in an animal model of proliferative vitreoretinopathy. Invest Ophthalmol Vis Sci 1993;34:522-530.

112. Arroyo MH, Refojo MF, Araiz JJ, Tolentino FI, Cajita VN, Elner VM. Silicone oil as a delivery vehicle for BCNU in rabbit proliferative vitreoretinopathy. Retina 1993;13:245-250. 


\section{Bibliagrafia}

113. Berger AS, Cheng CK, Pearson PA, et al. Intravitreal sustained release corticosteroid-5fluoruracil conjugate in the treatment of experimental proliferative vitreoretinopathy. Invest Ophthalmol Vis Sci 1996;37:2318-2325.

114. Charteris DG, Sethi CS, Lewis GP, Fisher SK. Proliferative vitreoretinopathy-developments in adjunctive treatment and retinal pathology. Eye (Lond) 2002;16:369-374.

115. Kobuch K, Herrmann WA, Framme C, Sachs HG, Gabel VP, Hillenkamp J. Maintenance of adult porcine retina and retinal pigment epithelium in perfusion culture: characterisation of an organotypic in vitro model. Exp Eye Res 2008;86:661-668.

116. Caffe AR, Ahuja P, Holmqvist B, et al. Mouse retina explants after long-term culture in serum free medium. J Chem Neuroanat 2001;22:263-273.

117. de Souza OF, Sakamoto T, Kimura H, et al. Inhibition of experimental proliferative vitreoretinopathy in rabbits by suramin. Ophthalmologica 1995;209:212-216.

118. Fastenberg DM, Diddie KR, Sorgente N, Ryan SJ. A comparison of different cellular inocula in an experimental model of massive periretinal proliferation. Am J Ophthalmol 1982;93:559-564.

119. Fastenberg DM, Diddie KR, Dorey K, Ryan SJ. The role of cellular proliferation in an experimental model of massive periretinal proliferation. Am J Ophthalmol 1982;93:565-572.

120. Wiedemann P, Sorgente N, Ryan SJ. Proliferative vitreoretinopathy: the rabbit cell injection model for screening of antiproliferative drugs. J Pharmacol Methods 1984;12:69-78.

121. Tano Y, Sugita G, Abrams G, Machemer R. Inhibition of intraocular proliferations with intravitreal corticosteroids. Am J Ophthalmol 1980;89:131-136.

122. Hida T, Chandler DB, Sheta SM. Classification of the stages of proliferative vitreoretinopathy in a refined experimental model in the rabbit eye. Graefes Arch Clin Exp Ophthalmol 1987;225:303-307.

123. Hsu HT, Dorey K, Sorgente N, Ryan SJ. Surgical removal of vitreous. Its effect on intraocular fibroblast proliferation in the rabbit. Arch Ophthalmol 1984;102:605-607.

124. Sugita G, Tano Y, Machemer R, Abrams G, Claflin A, Fiorentino G. Intravitreal autotransplantation of fibroblasts. Am J Ophthalmol 1980;89:121-130.

125. Radtke ND, Tano Y, Chandler D, Machemer R. Simulation of massive periretinal proliferation by autotransplantation of retinal pigment epithelial cells in rabbits. $A m \mathrm{~J}$ Ophthalmol 1981;91:76-87.

126. Cleary PE, Ryan SJ. Method of production and natural history of experimental posterior penetrating eye injury in the rhesus monkey. Am J Ophthalmol 1979;88:212-220.

127. Hsu HT, Ryan SJ. Natural history of penetrating ocular injury with retinal laceration in the monkey. Graefes Arch Clin Exp Ophthalmol 1986;224:1-6.

128. Cleary PE, Ryan SJ. Vitrectomy in penetrating eye injury. Results of a controlled trial of vitrectomy in an experimental posterior penetrating eye injury in the rhesus monkey. Arch Ophthalmol 1981;99:287-292.

129. Canto Soler MV, Gallo JE, Dodds RA, Suburo AM. A mouse model of proliferative vitreoretinopathy induced by dispase. Exp Eye Res 2002;75:491-504.

130. Hendrickson A, Hicks D. Distribution and density of medium- and short-wavelength selective cones in the domestic pig retina. Exp Eye Res 2002;74:435-444. 
131. Chandler MJ, Smith PJ, Samuelson DA, MacKay EO. Photoreceptor density of the domestic pig retina. Vet Ophthalmol 1999;2:179-184.

132. Jackson TL, Hillenkamp J, Williamson TH, Clarke KW, Almubarak AI, Marshall J. An experimental model of rhegmatogenous retinal detachment: surgical results and glial cell response. Invest Ophthalmol Vis Sci 2003;44:4026-4034.

133. Garcia-Layana A, Pastor JC, Saornil MA, Gonzalez G. Porcine model of proliferative vitreoretinopathy with platelets. Curr Eye Res 1997;16:556-563.

134. Algvere P, Kock E. Experimental Fibroplasia in the rabbit vitreous. Retinal detachment induced by autologous fibroblasts. Albrecht Von Graefes Arch Klin Exp Ophthalmol 1976;199:215-222.

135. Gonvers M, Thresher R. Temporary use of silicone oil in the treatment of proliferative vitreoretinopathy. An experimental study with a new animal model. Graefes Arch Clin Exp Ophthalmol 1983;221:46-53.

136. Lean JS, van der Zee WA, Ryan SJ. Experimental model of proliferative vitreoretinopathy (PVR) in the vitrectomised eye: effect of silicone oil. Br J Ophthalmol 1984;68:332-335.

137. Chandler DB, Quansah FA, Hida T, Machemer R. A refined experimental model for proliferative vitreoretinopathy. Graefes Arch Clin Exp Ophthalmol 1986;224:86-91.

138. Sakamoto T, Kimura H, Scuric Z, et al. Inhibition of experimental proliferative vitreoretinopathy by retroviral vector-mediated transfer of suicide gene. Can proliferative vitreoretinopathy be a target of gene therapy? Ophthalmology 1995;102:1417-1424.

139. Hui YN, Sorgente N, Ryan SJ. Posterior vitreous separation and retinal detachment induced by macrophages. Graefes Arch Clin Exp Ophthalmol 1987;225:279-284.

140. Hui YN, Goodnight R, Sorgente N, Ryan SJ. Fibrovascular proliferation and retinal detachment after intravitreal injection of activated macrophages in the rabbit eye. Am J Ophthalmol 1989;108:176-184.

141. Pinon RM, Pastor JC, Saornil MA, et al. Intravitreal and subretinal proliferation induced by platelet-rich plasma injection in rabbits. Curr Eye Res 1992;11:1047-1055.

142. Goldaracena MB, Garcia-Layana A, Pastor JC, Saornil MA, de la Fuente F, Gayoso MJ. The role of retinotomy in an experimental rabbit model of proliferative vitreoretinopathy. Curr Eye Res 1997;16:422-427.

143. Pastor JC, Rodriguez E, Marcos MA, Lopez MI. Combined pharmacologic therapy in a rabbit model of proliferative vitreoretinopathy (PVR). Ophthalmic Res 2000;32:25-29.

144. Liou GI, Pakalnis VA, Matragoon S, et al. HGF regulation of RPE proliferation in an IL-1beta/retinal hole-induced rabbit model of PVR. Mol Vis 2002;8:494-501.

145. Planck SR, Andresevic J, Chen JC, et al. Expression of growth factor mRNA in rabbit PVR model systems. Curr Eye Res 1992;11:1031-1039.

146. Wong CA, Potter MJ, Cui JZ, et al. Induction of proliferative vitreoretinopathy by a unique line of human retinal pigment epithelial cells. Can J Ophthalmol 2002;37:211-220.

147. Chinn C, Spee C, Barron E, Ryan SJ, Hinton DR. Strain-dependent gene expression in a lens extraction PVR model. Invest Ophthalmol Vis Sci 2005;46:ARVO E-Abstract 5528.

148. Saika S, Yamanaka O, Ikeda K, et al. Inhibition of p38MAP kinase suppresses fibrotic reaction of retinal pigment epithelial cells. Lab Invest 2005;85:838-850. 


\section{Bibliagrafia}

149. Saika S, Kono-Saika S, Tanaka T, et al. Smad3 is required for dedifferentiation of retinal pigment epithelium following retinal detachment in mice. Lab Invest 2004;84:1245-1258.

150. Frenzel EM, Neely KA, Walsh AW, Cameron JD, Gregerson DS. A new model of proliferative vitreoretinopathy. Invest Ophthalmol Vis Sci 1998;39:2157-2164.

151. Kralinger MT, Kieselbach GF, Voigt M, et al. Experimental model for proliferative vitreoretinopathy by intravitreal dispase: limited by zonulolysis and cataract. Ophthalmologica 2006;220:211-216.

152. Jin M, Chen Y, He S, Ryan SJ, Hinton DR. Hepatocyte growth factor and its role in the pathogenesis of retinal detachment. Invest Ophthalmol Vis Sci 2004;45:323-329.

153. Seo MS, Okamoto N, Vinores MA, et al. Photoreceptor-specific expression of plateletderived growth factor-B results in traction retinal detachment. Am J Pathol 2000;157:995-1005.

154. Yamada H, Yamada E, Ando A, et al. Platelet-derived growth factor-A-induced retinal gliosis protects against ischemic retinopathy. Am J Pathol 2000;156:477-487.

155. Akiyama $\mathrm{H}$, Kachi S, Silva RL, et al. Intraocular injection of an aptamer that binds PDGF-B: a potential treatment for proliferative retinopathies. J Cell Physiol 2006;207:407-412.

156. Kimura H, Sakamoto T, Cardillo JA, et al. Retrovirus-mediated suicide gene transduction in the vitreous cavity of the eye: feasibility in prevention of proliferative vitreoretinopathy. Hum Gene Ther 1996;7:799-808.

157. De Schaepdrijver L, Simoens P, Lauwers H, De Geest JP. Retinal vascular patterns in domestic animals. Res Vet Sci 1989;47:34-42.

158. De Schaepdrijver L, Simoens P, Pollet L, Lauwers H, De Laey JJ. Morphologic and clinical study of the retinal circulation in the miniature pig. B: Fluorescein angiography of the retina. Exp Eye Res 1992;54:975-985.

159. Simoens $P$, De Schaepdrijver L, Lauwers H. Morphologic and clinical study of the retinal circulation in the miniature pig. A: Morphology of the retinal microvasculature. Exp Eye Res 1992;54:965-973.

160. Forrester JV, Docherty R, Kerr C, Lackie JM. Cellular proliferation in the vitreous: the use of vitreous explants as a model system. Invest Ophthalmol Vis Sci 1986;27:1085-1094.

161. Jin M, He S, Worpel V, Ryan SJ, Hinton DR. Promotion of adhesion and migration of RPE cells to provisional extracellular matrices by TNF-alpha. Invest Ophthalmol Vis Sci 2000;41:4324-4332.

162. Gamulescu MA, Chen Y, He S, et al. Transforming growth factor beta2-induced myofibroblastic differentiation of human retinal pigment epithelial cells: regulation by extracellular matrix proteins and hepatocyte growth factor. Exp Eye Res 2006;83:212-222.

163. Guidry C. Isolation and characterization of porcine Muller cells. Myofibroblastic dedifferentiation in culture. Invest Ophthalmol Vis Sci 1996;37:740-752.

164. Guidry C. Tractional force generation by porcine Muller cells. Development and differential stimulation by growth factors. Invest Ophthalmol Vis Sci 1997;38:456-468.

165. Guidry C, Bradley KM, King JL. Tractional force generation by human muller cells: growth factor responsiveness and integrin receptor involvement. Invest Ophthalmol Vis Sci 2003;44:1355-1363. 
166. Guidry C. The role of Muller cells in fibrocontractive retinal disorders. Prog Retin Eye Res 2005;24:75-86.

167. Hardwick C, Feist R, Morris R, et al. Tractional force generation by porcine Muller cells: stimulation by growth factors in human vitreous. Invest Ophthalmol Vis Sci 1997;38:2053-2063.

168. Strangeways TSP, Honor BF. Experimental studies on the differentiation of embryonic tissues growing in vivo and in vitro. II The development of the isolated early embryonic eye of the fowl when cultivated in vitro. Proc R Soc Lond B 1926;100:273-283.

169. Tansley K. The formation of rosettes in the rat retina. Br J Ophthalmol 1933;17:321-336.

170. Trowell OA. A modified technique for organ culture in vitro. Exp Cell Res 1954;6:246-248.

171. Lucas DR. Inherited retinal dystrophy in the mouse: its appearance in eyes and retinae cultured in vitro. J Embryol Exp Morphol 1958;6:589-592.

172. Lucas DR, Trowell OA. In vitro culture of the eye and the retina of the mouse and rat. $J$ Embryol Exp Morphol 1958;6:178-182.

173. Sidman RL. Organ-culture analysis of inherited retinal degeneration in rodents. Natl Cancer Inst Monogr 1963;11:227-246.

174. Tamai M, Takahashi J, Noji T, Mizuno K. Development of photoreceptor cells in vitro: influence and phagocytic activity of homo- and heterogenic pigment epithelium. Exp Eye Res 1978;26:581-590.

175. Caffe AR, Visser $H$, Jansen HG, Sanyal S. Histotypic differentiation of neonatal mouse retina in organ culture. Curr Eye Res 1989;8:1083-1092.

176. Caffe AR, Soderpalm A, van Veen T. Photoreceptor-specific protein expression of mouse retina in organ culture and retardation of rd degeneration in vitro by a combination of basic fibroblast and nerve growth factors. Curr Eye Res 1993;12:719-726.

177. Engelsberg K, Johansson K, Ghosh F. Development of the embryonic porcine neuroretina in vitro. Ophthalmic Res 2005;37:104-111.

178. Ogilvie JM, Speck JD, Lett JM, Fleming TT. A reliable method for organ culture of neonatal mouse retina with long-term survival. J Neurosci Methods 1999;87:57-65.

179. Katsuki H, Yamamoto R, Nakata D, Kume T, Akaike A. Neuronal nitric oxide synthase is crucial for ganglion cell death in rat retinal explant cultures. J Pharmacol Sci 2004;94:77-80.

180. Cossenza M, Cadilhe DV, Coutinho RN, Paes-de-Carvalho R. Inhibition of protein synthesis by activation of NMDA receptors in cultured retinal cells: a new mechanism for the regulation of nitric oxide production. J Neurochem 2006;97:1481-1493.

181. Hartani D, Belguendouz H, Guenane H, Chachoua L, Lahlou-Boukoffa OQ, Touil-Boukoffa C. [Effect of nitrites and nitrates on bovine retina in vitro]. J Fr Ophtalmol 2006;29:32-36.

182. Allamby D, Foreman D, Carrington L, McLeod D, Boulton M. Cell attachment to, and contraction of, the retina in vitro. Invest Ophthalmol Vis Sci 1997;38:2064-2072.

183. Koizumi A, Zeck G, Ben Y, Masland RH, Jakobs TC. Organotypic culture of physiologically functional adult mammalian retinas. PLoS One 2007;2:e221. 


\section{Bibliagrafia}

184. Syed H, Safa R, Chidlow G, Osborne NN. Sulfisoxazole, an endothelin receptor antagonist, protects retinal neurones from insults of ischemia/reperfusion or lipopolysaccharide. Neurochem Int 2006;48:708-717.

185. Delyfer MN, Simonutti M, Neveux N, Leveillard T, Sahel JA. Does GDNF exert its neuroprotective effects on photoreceptors in the rd1 retina through the glial glutamate transporter GLAST? Mol Vis 2005;11:677-687.

186. Franke AG, Gubbe C, Beier M, Duenker N. Transforming growth factor-beta and bone morphogenetic proteins: cooperative players in chick and murine programmed retinal cell death. J Comp Neurol 2006;495:263-278.

187. Lagreze WA, Pielen A, Steingart R, et al. The peptides ADNF-9 and NAP increase survival and neurite outgrowth of rat retinal ganglion cells in vitro. Invest Ophthalmol Vis Sci 2005;46:933-938.

188. Garcia M, Forster V, Hicks D, Vecino E. Effects of muller glia on cell survival and neuritogenesis in adult porcine retina in vitro. Invest Ophthalmol Vis Sci 2002;43:3735-3743.

189. Saikia P, Maisch T, Kobuch K, et al. Safety testing of indocyanine green in an ex vivo porcine retina model. Invest Ophthalmol Vis Sci 2006;47:4998-5003.

190. Johnson TV, Martin KR. Development and characterization of an adult retinal explant organotypic tissue culture system as an in vitro intraocular stem cell transplantation model. Invest Ophthalmol Vis Sci 2008;49:3503-3512.

191. Luo J, Miller MW. Platelet-derived growth factor-mediated signal transduction underlying astrocyte proliferation: site of ethanol action. J Neurosci 1999;19:10014-10025.

192. Fujisawa K, Spee C, Hinton DR, Ryan SJ. PDGF-BB stimulates gliosis in a mouse organ culture model of PVR. Invest Ophthalmol Vis Sci 2003;44:ARVO E-Abstract 4982.

193. Anderson DH, Stern WH, Fisher SK, Erickson PA, Borgula GA. The onset of pigment epithelial proliferation after retinal detachment. Invest Ophthalmol Vis Sci 1981;21:10-16.

194. Limb GA, Hollifield RD, Webster L, Charteris DG, Chignell AH. Soluble TNF receptors in vitreoretinal proliferative disease. Invest Ophthalmol Vis Sci 2001;42:1586-1591.

195. Hinton DR, He S, Graf K, et al. Mitogen-activated protein kinase activation mediates PDGFdirected migration of RPE cells. Exp Cell Res 1998;239:11-15.

196. Campochiaro PA, Sugg R, Grotendorst G, Hjelmeland LM. Retinal pigment epithelial cells produce PDGF-like proteins and secrete them into their media. Exp Eye Res 1989;49:217-227.

197. Andrews A, Balciunaite E, Leong FL, et al. Platelet-derived growth factor plays a key role in proliferative vitreoretinopathy. Invest Ophthalmol Vis Sci 1999;40:2683-2689.

198. Ikuno Y, Leong FL, Kazlauskas A. Attenuation of experimental proliferative vitreoretinopathy by inhibiting the platelet-derived growth factor receptor. Invest Ophthalmol Vis Sci 2000;41:3107-3116.

199. Cicik E, Tekin H, Akar S, et al. Interleukin-8, nitric oxide and glutathione status in proliferative vitreoretinopathy and proliferative diabetic retinopathy. Ophthalmic Res 2003;35:251-255. 
200. La Heij EC, van de Waarenburg MP, Blaauwgeers HG, et al. Basic fibroblast growth factor, glutamine synthetase, and interleukin-6 in vitreous fluid from eyes with retinal detachment complicated by proliferative vitreoretinopathy. Am J Ophthalmol 2002;134:367-375.

201. Harada C, Harada T, Mitamura Y, et al. Diverse NF-kappaB expression in epiretinal membranes after human diabetic retinopathy and proliferative vitreoretinopathy. Mol Vis 2004;10:31-36.

202. Kon $\mathrm{CH}$, Occleston NL, Charteris D, Daniels J, Aylward GW, Khaw PT. A prospective study of matrix metalloproteinases in proliferative vitreoretinopathy. Invest Ophthalmol Vis Sci 1998;39:1524-1529.

203. Webster L, Chignell AH, Limb GA. Predominance of MMP-1 and MMP-2 in epiretinal and subretinal membranes of proliferative vitreoretinopathy. Exp Eye Res 1999;68:91-98.

204. El-Ghrably IA, Dua HS, Orr GM, Fischer D, Tighe PJ. Intravitreal invading cells contribute to vitreal cytokine milieu in proliferative vitreoretinopathy. Br J Ophthalmol 2001;85:461-470.

205. Limb GA, Little BC, Meager A, et al. Cytokines in proliferative vitreoretinopathy. Eye (Lond) 1991;5 ( Pt 6):686-693.

206. Cui JZ, Chiu A, Maberley D, Ma P, Samad A, Matsubara JA. Stage specificity of novel growth factor expression during development of proliferative vitreoretinopathy. Eye (Lond) 2007;21:200-208.

207. Heidenkummer HP, Kampik A. Immunohistochemical localization of epidermal growth factor receptor in a human epiretinal membrane. Graefes Arch Clin Exp Ophthalmol 1991;229:492-496.

208. Hueber A, Wiedemann P, Esser P, Heimann K. Basic fibroblast growth factor mRNA, bFGF peptide and FGF receptor in epiretinal membranes of intraocular proliferative disorders (PVR and PDR). Int Ophthalmol 1996;20:345-350.

209. Cassidy L, Barry P, Shaw C, Duffy J, Kennedy S. Platelet derived growth factor and fibroblast growth factor basic levels in the vitreous of patients with vitreoretinal disorders. $\mathrm{Br}$ J Ophthalmol 1998;82:181-185.

210. Mitamura Y, Takeuchi S, Matsuda A, Tagawa Y, Mizue Y, Nishihira J. Monocyte chemotactic protein-1 in the vitreous of patients with proliferative diabetic retinopathy. Ophthalmologica 2001;215:415-418.

211. Hinton DR, He S, Jin ML, Barron E, Ryan SJ. Novel growth factors involved in the pathogenesis of proliferative vitreoretinopathy. Eye (Lond) 2002;16:422-428.

212. Vassalli P. The pathophysiology of tumor necrosis factors. Annu Rev Immunol 1992;10:411-452.

213. Wallach D. Cell death induction by TNF: a matter of self control. Trends Biochem Sci 1997;22:107-109.

214. Vandenabeele P, Declercq W, Beyaert R, Fiers W. Two tumour necrosis factor receptors: structure and function. Trends Cell Biol 1995;5:392-399.

215. Smith CA, Farrah T, Goodwin RG. The TNF receptor superfamily of cellular and viral proteins: activation, costimulation, and death. Cell 1994;76:959-962.

216. Baud V, Karin M. Signal transduction by tumor necrosis factor and its relatives. Trends Cell Biol 2001;11:372-377. 


\section{Bibliagrafia}

217. Wajant H, Pfizenmaier K, Scheurich P. Tumor necrosis factor signaling. Cell Death Differ 2003;10:45-65.

218. Saito K, Suyama K, Nishida K, Sei Y, Basile AS. Early increases in TNF-alpha, IL-6 and IL-1 beta levels following transient cerebral ischemia in gerbil brain. Neurosci Lett 1996;206:149-152.

219. Yang P, McKay BS, Allen JB, Jaffe GJ. Effect of NF-kappa B inhibition on TNF-alphainduced apoptosis in human RPE cells. Invest Ophthalmol Vis Sci 2004;45:2438-2446.

220. Rodrigues EB, Farah ME, Maia M, et al. Therapeutic monoclonal antibodies in ophthalmology. Prog Retin Eye Res 2009;28:117-144.

221. Csaszar A, Abel T. Receptor polymorphisms and diseases. Eur J Pharmacol 2001;414:9-22.

222. Gehr G, Gentz R, Brockhaus M, Loetscher H, Lesslauer W. Both tumor necrosis factor receptor types mediate proliferative signals in human mononuclear cell activation. $J$ Immunol 1992;149:911-917.

223. Li X, Yang Y, Ashwell JD. TNF-RII and C-IAP1 mediate ubiquitination and degradation of TRAF2. Nature 2002;416:345-347.

224. Aderka D, Engelmann H, Maor Y, Brakebusch C, Wallach D. Stabilization of the bioactivity of tumor necrosis factor by its soluble receptors. J Exp Med 1992;175:323-329.

225. Tezel G, Wax MB. Increased production of tumor necrosis factor-alpha by glial cells exposed to simulated ischemia or elevated hydrostatic pressure induces apoptosis in cocultured retinal ganglion cells. J Neurosci 2000;20:8693-8700.

226. Diem R, Meyer R, Weishaupt JH, Bahr M. Reduction of potassium currents and phosphatidylinositol 3-kinase-dependent AKT phosphorylation by tumor necrosis factor(alpha) rescues axotomized retinal ganglion cells from retrograde cell death in vivo. $J$ Neurosci 2001;21:2058-2066.

227. Micheau O, Tschopp J. Induction of TNF receptor I-mediated apoptosis via two sequential signaling complexes. Cell 2003;114:181-190.

228. Sheppard D. Transforming growth factor beta: a central modulator of pulmonary and airway inflammation and fibrosis. Proc Am Thorac Soc 2006;3:413-417.

229. Priglinger SG, May CA, Neubauer AS, et al. Tissue transglutaminase as a modifying enzyme of the extracellular matrix in PVR membranes. Invest Ophthalmol Vis Sci 2003;44:355-364.

230. Bottner $\mathrm{M}$, Krieglstein $\mathrm{K}$, Unsicker $\mathrm{K}$. The transforming growth factor-betas: structure, signaling, and roles in nervous system development and functions. $J$ Neurochem 2000;75:2227-2240.

231. Bornstein P. Thrombospondins as matricellular modulators of cell function. $J$ Clin Invest 2001;107:929-934.

232. Flanders KC. Smad3 as a mediator of the fibrotic response. Int $J$ Exp Pathol 2004;85:47-64.

233. Ikuno Y, Kazlauskas A. TGFbeta1-dependent contraction of fibroblasts is mediated by the PDGFalpha receptor. Invest Ophthalmol Vis Sci 2002;43:41-46. 
234. Nagineni CN, Kutty V, Detrick B, Hooks JJ. Expression of PDGF and their receptors in human retinal pigment epithelial cells and fibroblasts: regulation by TGF-beta. $J$ Cell Physiol 2005;203:35-43.

235. Maier P, Broszinski A, Heizmann U, Boehringer D, Reinhard T. Determination of active TGF-beta2 in aqueous humor prior to and following cryopreservation. Mol Vis 2006;12:1477-1482.

236. Connor TB, Jr., Roberts $A B$, Sporn MB, et al. Correlation of fibrosis and transforming growth factor-beta type 2 levels in the eye. J Clin Invest 1989;83:1661-1666.

237. Saika S. TGFbeta pathobiology in the eye. Lab Invest 2006;86:106-115.

238. Bandyopadhyay B, Fan J, Guan S, et al. A "traffic control" role for TGFbeta3: orchestrating dermal and epidermal cell motility during wound healing. J Cell Biol 2006;172:1093-1105.

239. Cui JZ, Chiu A, Maberley D, Ma P, Samad A, Matsubara JA. Stage specificity of novel growth factor expression during development of proliferative vitreoretinopathy. Eye 2007;21:200-208.

240. Grisanti S, Guidry C. Transdifferentiation of retinal pigment epithelial cells from epithelial to mesenchymal phenotype. Invest Ophthalmol Vis Sci 1995;36:391-405.

241. Bando H, Ikuno Y, Hori Y, Sayanagi K, Tano Y. Mitogen-activated protein kinase (MAPK) and phosphatidylinositol-3 kinase (PI3K) pathways differently regulate retinal pigment epithelial cell-mediated collagen gel contraction. Exp Eye Res 2006;82:529-537.

242. Chen B, Jiand D, Huang P, Tang L. [Relationship between IL-1 beta and TNF-alpha in subretinal fluids of rhegmatogenous retinal detachment with PVR]. Hunan Yi Ke Da Xue Xue Bao 1998;23:483-485.

243. Bernhagen J, Calandra T, Bucala R. Regulation of the immune response by macrophage migration inhibitory factor: biological and structural features. J Mol Med 1998;76:151-161.

244. Mitamura Y, Takeuchi S, Matsuda A, Tagawa Y, Mizue Y, Nishihira J. Macrophage migration inhibitory factor levels in the vitreous of patients with proliferative vitreoretinopathy. $A m \mathrm{~J}$ Ophthalmol 1999;128:763-765.

245. Hochberg MC, Lebwohl MG, Plevy SE, Hobbs KF, Yocum DE. The benefit/risk profile of TNF-blocking agents: findings of a consensus panel. Semin Arthritis Rheum 2005;34:819-836.

246. Mazumdar S, Greenwald D. Golimumab. MAbs 2009;1:422-431.

247. Goel N, Stephens S. Certolizumab pegol. MAbs 2010;2:137-147.

248. Enbrel®. In: etanercept. Thousand Oaks, CA: Immunex Corporation. Marketed by Amgen and Wyeth Pharmaceuticals; 2006.

249. Remicadeß. In: infliximab. Malvern, PA: Centocor Inc.; 2007.

250. Humira ${ }^{\circledR}$. In: adalimumab. North Chicago, IL: Abbott Laboratories; 2007.

251. Arora T, Padaki R, Liu L, et al. Differences in binding and effector functions between classes of TNF antagonists. Cytokine 2009;45:124-131.

252. Calabrese LH. Molecular differences in anticytokine therapies. Clin Exp Rheumatol 2003;21:241-248.

253. Haraoui B. Differentiating the efficacy of the tumor necrosis factor inhibitors. Semin Arthritis Rheum 2005;34:7-11. 


\section{Bibliagrafia}

254. Deo YM, Graziano RF, Repp R, van de Winkel JG. Clinical significance of IgG Fc receptors and Fc gamma R-directed immunotherapies. Immunol Today 1997;18:127-135.

255. Imrie FR, Dick AD. Biologics in the treatment of uveitis. Curr Opin Ophthalmol 2007;18:481-486.

256. Lim L, Suhler EB, Smith JR. Biologic therapies for inflammatory eye disease. Clin Experiment Ophthalmol 2006;34:365-374.

257. Galor A, Perez VL, Hammel JP, Lowder CY. Differential effectiveness of etanercept and infliximab in the treatment of ocular inflammation. Ophthalmology 2006;113:2317-2323.

258. Gallagher M, Quinones K, Cervantes-Castaneda RA, Yilmaz T, Foster CS. Biological response modifier therapy for refractory childhood uveitis. $\mathrm{Br} \mathrm{J}$ Ophthalmol 2007;91:1341-1344.

259. ten Hove T, van Montfrans C, Peppelenbosch MP, van Deventer SJ. Infliximab treatment induces apoptosis of lamina propria $\mathrm{T}$ lymphocytes in Crohn's disease. Gut 2002;50:206-211.

260. Sobrin L, Kim EC, Christen W, Papadaki T, Letko E, Foster CS. Infliximab therapy for the treatment of refractory ocular inflammatory disease. Arch Ophthalmol 2007;125:895-900.

261. Sfikakis PP, Markomichelakis N, Alpsoy E, et al. Anti-TNF therapy in the management of Behcet's disease--review and basis for recommendations. Rheumatology (Oxford) 2007;46:736-741.

262. Niccoli L, Nannini C, Benucci M, et al. Long-term efficacy of infliximab in refractory posterior uveitis of Behcet's disease: a 24-month follow-up study. Rheumatology (Oxford) 2007;46:1161-1164.

263. Tugal-Tutkun I, Mudun A, Urgancioglu M, et al. Efficacy of infliximab in the treatment of uveitis that is resistant to treatment with the combination of azathioprine, cyclosporine, and corticosteroids in Behcet's disease: an open-label trial. Arthritis Rheum 2005;52:2478-2484.

264. Biester $\mathrm{S}$, Deuter $\mathrm{C}$, Michels $\mathrm{H}$, et al. Adalimumab in the therapy of uveitis in childhood. $\mathrm{Br}$ J Ophthalmol 2007;91:319-324.

265. Mushtaq B, Saeed T, Situnayake RD, Murray PI. Adalimumab for sight-threatening uveitis in Behcet's disease. Eye (Lond) 2007;21:824-825.

266. Nesbitt A, Fossati G, Bergin M, et al. Mechanism of action of certolizumab pegol (CDP870): in vitro comparison with other anti-tumor necrosis factor alpha agents. Inflamm Bowel Dis 2007;13:1323-1332.

267. Fauser S, Kalbacher H, Alteheld N, Koizumi K, Krohne TU, Joussen AM. Pharmacokinetics and safety of intravitreally delivered etanercept. Graefes Arch Clin Exp Ophthalmol 2004;242:582-586.

268. Kivilcim M, Peyman GA, Kazi AA, Dellacroce J, Ghobrial RN, Monzano R. Intravitreal toxicity of high-dose etanercept. J Ocul Pharmacol Ther 2007;23:57-62.

269. Giansanti F, Ramazzotti M, Vannozzi L, et al. A pilot study on ocular safety of intravitreal infliximab in a rabbit model. Invest Ophthalmol Vis Sci 2008;49:1151-1156.

270. Giansanti F, Ramazzotti M, Giuntoli M, et al. Intravitreal infliximab clearance in a rabbit model: different sampling methods and assay techniques. Invest Ophthalmol Vis Sci 2009;50:5328-5335. 
271. Regatieri CV, Dreyfuss JL, Melo GB, Lavinsky D, Farah ME, Nader HB. Dual role of intravitreous infliximab in experimental choroidal neovascularization: effect on the expression of sulfated glycosaminoglycans. Invest Ophthalmol Vis Sci 2009;50:5487-5494.

272. Theodossiadis PG, Liarakos VS, Sfikakis PP, Vergados IA, Theodossiadis GP. Intravitreal administration of the anti-tumor necrosis factor agent infliximab for neovascular age-related macular degeneration. Am J Ophthalmol 2009;147:825-830, 830 e821.

273. Manzano RP, Peyman GA, Carvounis PE, et al. Ocular toxicity of intravitreous adalimumab (Humira) in the rabbit. Graefes Arch Clin Exp Ophthalmol 2008;246:907-911.

274. Tsilimbaris M, Diakonis VF, Naoumidi I, et al. Evaluation of potential retinal toxicity of adalimumab (Humira). Graefes Arch Clin Exp Ophthalmol 2009;247:1119-1125.

275. Chamorro S, Revilla C, Alvarez B, Alonso F, Ezquerra A, Dominguez J. Phenotypic and functional heterogeneity of porcine blood monocytes and its relation with maturation. Immunology 2005;114:63-71.

276. Minoguchi K, Tazaki T, Yokoe T, et al. Elevated production of tumor necrosis factor-alpha by monocytes in patients with obstructive sleep apnea syndrome. Chest 2004;126:1473-1479.

277. Mizutani H, Ohmoto Y, Mizutani T, Murata M, Shimizu M. Role of increased production of monocytes TNF-alpha, IL-1beta and IL-6 in psoriasis: relation to focal infection, disease activity and responses to treatments. J Dermatol Sci 1997;14:145-153.

278. Hamdi H, Mariette X, Godot V, et al. Inhibition of anti-tuberculosis T-lymphocyte function with tumour necrosis factor antagonists. Arthritis Res Ther 2006;8:R114.

279. Saliu OY, Sofer C, Stein DS, Schwander SK, Wallis RS. Tumor-necrosis-factor blockers: differential effects on mycobacterial immunity. J Infect Dis 2006;194:486-492.

280. Boyum A. Separation of lymphocytes, lymphocyte subgroups and monocytes: a review. Lymphology 1977;10:71-76.

281. Gonzalez S, Mendoza C, Sanchez-Vizcaino JM, Alonso F. Inhibitory effect of African swine fever virus on lectin-dependent swine lymphocyte proliferation. Vet Immunol Immunopathol 1990;26:71-80.

282. Ekstrom P, Sanyal S, Narfstrom K, Chader GJ, van Veen T. Accumulation of glial fibrillary acidic protein in Muller radial glia during retinal degeneration. Invest Ophthalmol Vis Sci 1988;29:1363-1371.

283. Sarthy PV, Fu M. Transcriptional activation of an intermediate filament protein gene in mice with retinal dystrophy. Dna 1989;8:437-446.

284. Lewis GP, Guerin CJ, Anderson DH, Matsumoto B, Fisher SK. Rapid changes in the expression of glial cell proteins caused by experimental retinal detachment. Am $J$ Ophthalmol 1994;118:368-376.

285. Bunt-Milam AH, Saari JC. Immunocytochemical localization of two retinoid-binding proteins in vertebrate retina. J Cell Biol 1983;97:703-712.

286. Johnson PT, Geller SF, Lewis GP, Reese BE. Cellular retinaldehyde binding protein in developing retinal astrocytes. Exp Eye Res 1997;64:759-766.

287. Guerin CJ, Anderson DH, Fisher SK. Changes in intermediate filament immunolabeling occur in response to retinal detachment and reattachment in primates. Invest Ophthalmol Vis Sci 1990;31:1474-1482. 


\section{Bibliagrafia}

288. McCullough KC, Schaffner R, Natale V, Kim YB, Summerfield A. Phenotype of porcine monocytic cells: modulation of surface molecule expression upon monocyte differentiation into macrophages. Vet Immunol Immunopathol 1997;58:265-275.

289. McCullough KC, Basta S, Knotig S, et al. Intermediate stages in monocyte-macrophage differentiation modulate phenotype and susceptibility to virus infection. Immunology 1999;98:203-212.

290. Hebel R. Distribution of retinal ganglion cells in five mammalian species (pig, sheep, ox, horse, dog). Anat Embryol (Berl) 1976;150:45-51.

291. Sakai T, Lewis GP, Linberg KA, Fisher SK. The ability of hyperoxia to limit the effects of experimental detachment in cone-dominated retina. Invest Ophthalmol Vis Sci 2001;42:3264-3273.

292. Jacobs GH, Calderone JB, Sakai T, Lewis GP, Fisher SK. An animal model for studying cone function in retinal detachment. Doc Ophthalmol 2002;104:119-132.

293. Lewis GP, Sethi CS, Carter KM, Charteris DG, Fisher SK. Microglial cell activation following retinal detachment: a comparison between species. Mol Vis 2005;11:491-500.

294. Iandiev I, Uckermann O, Pannicke T, et al. Glial cell reactivity in a porcine model of retinal detachment. Invest Ophthalmol Vis Sci 2006;47:2161-2171.

295. Kaempf S, Walter P, Salz AK, Thumann G. Novel organotypic culture model of adult mammalian neurosensory retina in co-culture with retinal pigment epithelium. $J$ Neurosci Methods 2008;173:47-58.

296. Kaempf S, Johnen S, Salz AK, Weinberger A, Walter P, Thumann G. Effects of bevacizumab (Avastin) on retinal cells in organotypic culture. Invest Ophthalmol Vis Sci 2008;49:3164-3171.

297. Kuhrt H, Walski M, Reichenbach A, Albrecht J. Rabbit retinal organ culture as an in-vitro model of hepatic retinopathy. Graefes Arch Clin Exp Ophthalmol 2004;242:512-522.

298. Lye $\mathrm{MH}$, Jakobs TC, Masland $\mathrm{RH}$, Koizumi A. Organotypic culture of adult rabbit retina. $J$ Vis Exp 2007;190.

299. Brewer GJ, Torricelli JR, Evege EK, Price PJ. Optimized survival of hippocampal neurons in B27-supplemented Neurobasal, a new serum-free medium combination. J Neurosci Res 1993;35:567-576.

300. Viktorov IV, Aleksandrova OP, Alekseeva NY. Roller organ cultures of the retina from postnatal rats. Bull Exp Biol Med 2006;142:486-489.

301. Garcia M, Vecino E. Role of Muller glia in neuroprotection and regeneration in the retina. Histol Histopathol 2003;18:1205-1218.

302. Lewis GP, Fisher SK. Up-regulation of glial fibrillary acidic protein in response to retinal injury: its potential role in glial remodeling and a comparison to vimentin expression. Int Rev Cytol 2003;230:263-290.

303. Donato R. Intracellular and extracellular roles of $\mathrm{S} 100$ proteins. Microsc Res Tech 2003;60:540-551.

304. Garbuglia M, Verzini M, Sorci G, et al. The calcium-modulated proteins, S100A1 and $\mathrm{S} 100 \mathrm{~B}$, as potential regulators of the dynamics of type III intermediate filaments. Braz $J$ Med Biol Res 1999;32:1177-1185. 
305. Mertsch K, Hanisch UK, Kettenmann H, Schnitzer J. Characterization of microglial cells and their response to stimulation in an organotypic retinal culture system. J Comp Neurol 2001;431:217-227.

306. Hughes WF. Quantitation of ischemic damage in the rat retina. Exp Eye Res 1991;53:573-582.

307. Cook B, Lewis GP, Fisher SK, Adler R. Apoptotic photoreceptor degeneration in experimental retinal detachment. Invest Ophthalmol Vis Sci 1995;36:990-996.

308. Lewis GP, Charteris DG, Sethi CS, Fisher SK. Animal models of retinal detachment and reattachment: identifying cellular events that may affect visual recovery. Eye 2002;16:375-387.

309. Lewis GP, Charteris DG, Sethi CS, Leitner WP, Linberg KA, Fisher SK. The ability of rapid retinal reattachment to stop or reverse the cellular and molecular events initiated by detachment. Invest Ophthalmol Vis Sci 2002;43:2412-2420.

310. Nakazawa T, Matsubara A, Noda K, et al. Characterization of cytokine responses to retinal detachment in rats. Mol Vis 2006;12:867-878.

311. Lewis GP, Matsumoto B, Fisher SK. Changes in the organization and expression of cytoskeletal proteins during retinal degeneration induced by retinal detachment. Invest Ophthalmol Vis Sci 1995;36:2404-2416.

312. Chakrabarti S, Sima AA, Lee J, Brachet P, Dicou E. Nerve growth factor (NGF), proNGF and NGF receptor-like immunoreactivity in BB rat retina. Brain Res 1990;523:11-15.

313. Rickman DW, Brecha NC. Expression of the proto-oncogene, trk, receptors in the developing rat retina. Vis Neurosci 1995;12:215-222.

314. Ugolini G, Cremisi F, Maffei L. TrkA, TrkB and p75 mRNA expression is developmentally regulated in the rat retina. Brain Res 1995;704:121-124.

315. Cellerino A, Kohler K. Brain-derived neurotrophic factor/neurotrophin-4 receptor TrkB is localized on ganglion cells and dopaminergic amacrine cells in the vertebrate retina. $J$ Comp Neurol 1997;386:149-160.

316. Harada T, Harada C, Nakayama N, et al. Modification of glial-neuronal cell interactions prevents photoreceptor apoptosis during light-induced retinal degeneration. Neuron 2000;26:533-541.

317. Faktorovich EG, Steinberg RH, Yasumura D, Matthes MT, LaVail MM. Photoreceptor degeneration in inherited retinal dystrophy delayed by basic fibroblast growth factor. Nature 1990;347:83-86.

318. LaVail MM, Unoki K, Yasumura D, Matthes MT, Yancopoulos GD, Steinberg RH. Multiple growth factors, cytokines, and neurotrophins rescue photoreceptors from the damaging effects of constant light. Proc Natl Acad Sci U S A 1992;89:11249-11253.

319. Campochiaro PA, Chang M, Ohsato $M$, et al. Retinal degeneration in transgenic mice with photoreceptor-specific expression of a dominant-negative fibroblast growth factor receptor. J Neurosci 1996;16:1679-1688.

320. Harada T, Harada C, Kohsaka S, et al. Microglia-Muller glia cell interactions control neurotrophic factor production during light-induced retinal degeneration. $J$ Neurosci 2002;22:9228-9236. 


\section{Bibliagrafia}

321. Streit WJ. Microglia as neuroprotective, immunocompetent cells of the CNS. Glia 2002;40:133-139.

322. Walz W, Ilschner S, Ohlemeyer C, Banati R, Kettenmann H. Extracellular ATP activates a cation conductance and a $\mathrm{K}+$ conductance in cultured microglial cells from mouse brain. $J$ Neurosci 1993;13:4403-4411.

323. Whittemore ER, Korotzer AR, Etebari A, Cotman CW. Carbachol increases intracellular free calcium in cultured rat microglia. Brain Res 1993;621:59-64.

324. Giulian D, Baker TJ, Shih LC, Lachman LB. Interleukin 1 of the central nervous system is produced by ameboid microglia. J Exp Med 1986;164:594-604.

325. Miwa T, Furukawa S, Nakajima K, Furukawa Y, Kohsaka S. Lipopolysaccharide enhances synthesis of brain-derived neurotrophic factor in cultured rat microglia. $J$ Neurosci Res 1997;50:1023-1029.

326. Janabi N, Hau I, Tardieu M. Negative feedback between prostaglandin and alpha- and betachemokine synthesis in human microglial cells and astrocytes. J Immunol 1999;162:1701-1706.

327. Prinz M, Kann O, Draheim HJ, et al. Microglial activation by components of gram-positive and -negative bacteria: distinct and common routes to the induction of ion channels and cytokines. J Neuropathol Exp Neurol 1999;58:1078-1089.

328. Kreutzberg GW. Microglia: a sensor for pathological events in the CNS. Trends Neurosci 1996;19:312-318.

329. Uhlmann S, Bringmann A, Uckermann O, et al. Early glial cell reactivity in experimental retinal detachment: effect of suramin. Invest Ophthalmol Vis Sci 2003;44:4114-4122.

330. Ng TF, Streilein JW. Light-induced migration of retinal microglia into the subretinal space. Invest Ophthalmol Vis Sci 2001;42:3301-3310.

331. Humphrey MF, Moore SR. Microglial responses to focal lesions of the rabbit retina: correlation with neural and macroglial reactions. Glia 1996;16:325-341.

332. Gupta N, Brown KE, Milam AH. Activated microglia in human retinitis pigmentosa, lateonset retinal degeneration, and age-related macular degeneration. Exp Eye Res 2003;76:463-471.

333. Penfold PL, Madigan MC, Gillies MC, Provis JM. Immunological and aetiological aspects of macular degeneration. Prog Retin Eye Res 2001;20:385-414.

334. Naskar R, Wissing $M$, Thanos $S$. Detection of early neuron degeneration and accompanying microglial responses in the retina of a rat model of glaucoma. Invest Ophthalmol Vis Sci 2002;43:2962-2968.

335. Lam TT, Kwong JM, Tso MO. Early glial responses after acute elevated intraocular pressure in rats. Invest Ophthalmol Vis Sci 2003;44:638-645.

336. Martini B, Ryan SJ. Argon laser lesions of the retina; occurrence and origin of macrophages. Eur J Ophthalmol 1992;2:51-57.

337. Yamamoto C, Ogata N, Yi X, et al. Immunolocalization of transforming growth factor beta during wound repair in rat retina after laser photocoagulation. Graefes Arch Clin Exp Ophthalmol 1998;236:41-46. 
338. Roque RS, Rosales AA, Jingjing L, Agarwal N, Al-Ubaidi MR. Retina-derived microglial cells induce photoreceptor cell death in vitro. Brain Res 1999;836:110-119.

339. Roque RS, Imperial CJ, Caldwell RB. Microglial cells invade the outer retina as photoreceptors degenerate in Royal College of Surgeons rats. Invest Ophthalmol Vis Sci 1996;37:196-203.

340. Thanos S. Sick photoreceptors attract activated microglia from the ganglion cell layer: a model to study the inflammatory cascades in rats with inherited retinal dystrophy. Brain Res 1992;588:21-28.

341. Muller M, Stenner M, Wacker K, Ringelstein EB, Hickey WF, Kiefer R. Contribution of resident endoneurial macrophages to the local cellular response in experimental autoimmune neuritis. J Neuropathol Exp Neurol 2006;65:499-507.

342. Hume DA, Ross IL, Himes SR, Sasmono RT, Wells CA, Ravasi T. The mononuclear phagocyte system revisited. J Leukoc Biol 2002;72:621-627.

343. Hansson E, Ronnback L. Glial neuronal signaling in the central nervous system. Faseb $J$ 2003;17:341-348.

344. Nguyen VT, Benveniste EN. Critical role of tumor necrosis factor-alpha and NF-kappa B in interferon-gamma -induced CD40 expression in microglia/macrophages. J Biol Chem 2002;277:13796-13803.

345. Okada M, Matsumura M, Ogino N, Honda Y. Muller cells in detached human retina express glial fibrillary acidic protein and vimentin. Graefes Arch Clin Exp Ophthalmol 1990;228:467-474.

346. Heidenkummer HP, Kampik A. Proliferative activity and immunohistochemical cell differentiation in human epiretinal membranes. Ger J Ophthalmol 1992;1:170-175.

347. Morino I, Hiscott P, McKechnie N, Grierson I. Variation in epiretinal membrane components with clinical duration of the proliferative tissue. Br J Ophthalmol 1990;74:393-399.

348. Rittling SR, Baserga R. Functional analysis and growth factor regulation of the human vimentin promoter. Mol Cell Biol 1987;7:3908-3915.

349. Dominguez J, Ezquerra A, Alonso F, et al. Porcine myelonocytic markers: summary of the second international swine CD workshop. Vet Immunol Immunopathol 1998;60:329-341.

350. Dominguez J, Ezquerra A, Alonso F, et al. Workshop studies with monoclonal antibodies identifying a novel porcine differentiation antigen, SWC9. Vet Immunol Immunopathol 1998;60:343-349.

351. Meda L, Cassatella MA, Szendrei GI, et al. Activation of microglial cells by beta-amyloid protein and interferon-gamma. Nature 1995;374:647-650.

352. Streit WJ, Walter SA, Pennell NA. Reactive microgliosis. Prog Neurobiol 1999;57:563-581.

353. Brenner T, Yamin A, Abramsky O, Gallily R. Stimulation of tumor necrosis factor-alpha production by mycoplasmas and inhibition by dexamethasone in cultured astrocytes. Brain Res 1993;608:273-279.

354. Fuchs C, Forster V, Balse E, Sahel JA, Picaud S, Tessier LH. Retinal-cell-conditioned medium prevents TNF-alpha-induced apoptosis of purified ganglion cells. Invest Ophthalmol Vis Sci 2005;46:2983-2991. 


\section{Bibliagrafia}

355. Marc RE, Murry RF, Fisher SK, Linberg KA, Lewis GP. Amino acid signatures in the detached cat retina. Invest Ophthalmol Vis Sci 1998;39:1694-1702.

356. Dong Y, Benveniste EN. Immune function of astrocytes. Glia 2001;36:180-190.

357. Goureau O, Hicks D, Courtois Y, De Kozak Y. Induction and regulation of nitric oxide synthase in retinal Muller glial cells. J Neurochem 1994;63:310-317.

358. Tezel G, Wax MB. The immune system and glaucoma. Curr Opin Ophthalmol 2004;15:80-84.

359. Anderson DH, Guerin CJ, Erickson PA, Stern WH, Fisher SK. Morphological recovery in the reattached retina. Invest Ophthalmol Vis Sci 1986;27:168-183.

360. Friedlander M. Fibrosis and diseases of the eye. J Clin Invest 2007;117:576-586.

361. Ikeda T, Puro DG. Regulation of retinal glial cell proliferation by antiproliferative molecules. Exp Eye Res 1995;60:435-443.

362. Dyer MA, Cepko CL. Control of Muller glial cell proliferation and activation following retinal injury. Nat Neurosci 2000;3:873-880.

363. Milenkovic I, Birkenmeier G, Wiedemann P, Reichenbach A, Bringmann A. Effect of alpha2macroglobulin on retinal glial cell proliferation. Graefes Arch Clin Exp Ophthalmol 2005;243:811-816.

364. Eibl KH, Lewis GP, Betts $\mathrm{K}$, et al. The effect of alkylphosphocholines on intraretinal proliferation initiated by experimental retinal detachment. Invest Ophthalmol Vis Sci 2007;48:1305-1311.

365. Eibl KH, Schwabe K, Welge-Luessen U, Kampik A, Eichler W. The role of alkylphosphocholines in retinal Muller glial cell proliferation. Curr Eye Res 2008;33:385-393.

366. Eibl KH, Fisher SK, Lewis GP. Alkylphosphocholines: a new approach to inhibit cell proliferation in proliferative vitreoretinopathy. Dev Ophthalmol 2009;44:46-55.

367. Fischer AJ, Scott MA, Ritchey ER, Sherwood P. Mitogen-activated protein kinase-signaling regulates the ability of Muller glia to proliferate and protect retinal neurons against excitotoxicity. Glia 2009;57:1538-1552.

368. Mueller BK, Mack H, Teusch N. Rho kinase, a promising drug target for neurological disorders. Nat Rev Drug Discov 2005;4:387-398.

369. Sarbassov DD, Ali SM, Sabatini DM. Growing roles for the mTOR pathway. Curr Opin Cell Biol 2005;17:596-603.

370. Zhou P, Zhao MW, Li XX, Yu WZ, Bian ZM. siRNA targeting mammalian target of rapamycin (mTOR) attenuates experimental proliferative vitreoretinopathy. Curr Eye Res 2007;32:973-984.

371. Berger S, Savitz SI, Nijhawan S, et al. Deleterious role of TNF-alpha in retinal ischemiareperfusion injury. Invest Ophthalmol Vis Sci 2008;49:3605-3610. 
Anexa 1 



\title{
Müller and macrophage-like cell interactions in an organotypic culture of porcine neuroretina
}

\author{
Ivan Feruandez-Bueno, ${ }^{1}$ Jose Carlos Pastor, ${ }^{1}$ Masuel Jose Gayoso, ${ }^{2}$ Igaacio Alealde, ${ }^{2}$ Maria Teresa Gareia ${ }^{1}$

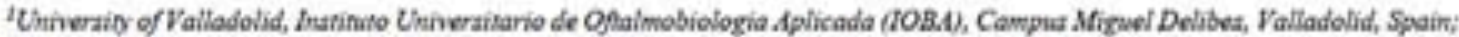

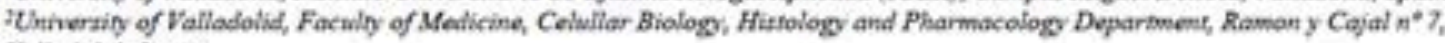 \\ Valladalid, Spain
}

\begin{abstract}
Parpose: To analyze the is vitro Maller cell modificaticas in an crganotypic culture of poscine neuroetina in response to the addition of a blood-derived mononuclear fraction (MNF; monocytes and byphocytes) as a source of macrophages. Methods: Control and MNF-stimulased nearoretinal explants were examined at 3, 6, and 9 days of culture. Specimens were peocessed for epoxy-fesin embedding and cryosectioning. Light and imminoflaorescence macroscopy were performed, asing toluidine blue stainmg and anzibodies against glial fibeillary acidic protein (GFAP), as a reactrve glsoss marker, and cellular retinaldetyde-binding protein (CRALBP), as a Meller cell marker Results: Comparod to controls, explants coculfured with MNF displayed increased cellular dusorganization and langer tiveve invasion of the subretinal space at 9 days of culture. Immunostaining of the MNF treated explants revealed evidence of more seactive gliosis and greater number of GFAP-immunoreactive Maller cells that had increased width and processes extending into the subretinal space and forming a moltilayer tissue. Astrocytes also responded to the MNF addition, producing extensions that invaded the neuroretinal outer layers. Conclusions: Addition of MNF stimulates modifications of Maller cells, producing a wider intraretinal reactive gliosis and tissue proliferation at the subretinal space (outer layers of the retina). These findings exiphasize the role of macrophage-hike cells in the production of changes in retinal structure obverved afier retinal detachmest is tumans
\end{abstract}

In the nomal retina, Muller cells surround neuroes in the retinal tissue [1] and have nuclei located at the inner nuclear layer (INL). The cytoplasm of Maller cells extends from the inner limiting membrane (IL.M) to the outer limiting membrane (OLM). After retinal detachment (RD), multiple modifications take plase at the eellular level of the neuroretins, including significant changes in Muller eells. The auclei become translocated to the extemal layers, and cell bodies become bypertrophic and hyperplastic. Their processes extend into the subretinal space, forming subretinal membranss and initiating a reactive gliosis [2-6]. All these findings have been described in experimental models and confirmed in luman retinal samples obtained during retinectomies from proliferative vitreoretinopathy (PVR) cases $[6-10]$.

Our group has previously reported a strong correlation between the development of PVR and the presence of macrophage-like cells in vitreous samples [11]. These cellk, which are $\mathrm{CD} 68$ positive and cytokeratin negative, are also present in human retinal tissue obtained from PVR retinestony specimens [9]. They probably derive from blood monosytes and are absent in normal human retina [12]. They

Correspondence to. Ivan Fernandez-Bueno. Univeruity of Valladolid. Instinato Universitario de Oftalmobiologia Aplicada (IOBA) Campar Miguel Deliber sn Valladolid, Valladolid 47011. Spain. Phone: +34 983 184 753: FAX +34 983210 824: email: if ernandexb groba mat wva.es infiltrate the retina and probably activate Maller dial cells. possibly via tumoe necrosis factor alpha (TNFu), as proposed in an experimental model of choroidal neovascularization [13]. These and other findings [14-18] emphasize the important role of macrophages in PVR development. The purpose of this work is to analyze the in vitro response of Milller eells to a mononuslear blood fraction containing monocytes and lymplosytes as a source of macrophages-

\section{METHODS}

Nearoretina explant preparation and organotypic culnure: Nineteen eyes from domestic pizs, age 6-8 months old, were obtained from the local daughterhonse and immersed in icecold transport medium composed of Dulbesco's Modified Eagle Medium (DMEM) CO,-independent medium without L-glutamine. This medimn was supplemented with $1 \%$ antibiotic-antimycotic mixture containing penicillin. streptonycin, and amphotericin B (Gibco, Paisley, UK), Eyes were transported on ice to the laboratory where, under aseptic conditions, each eyeball was immersed in $70 \%$ ethanol and washed in transport medium. With blunt scissors, all extraocular tissues were removed. Then the selera was punctured with a 22 gange peedle at the ora serrata and bisested with comeal scissors, dividing the ocular globe into anterior and posterior eyecups. The vitreous was removed, and the posterior syectip was placed into a dish with clean transport medium. A paintbrush was used to mechanically detach the neuroretina froen the rstinal pigmented spitbelium 
(RPE), and the optic nerve was cut with Westcott scissors. The neuroretina was unrolled and cut into $5 \times 5 \mathrm{~mm}$ explants, in such a way as to avoid visible blood vessels. Explants were transferred to Transwell culture dishes (Coming Inc., Corning NY), containing $1.6 \mathrm{ml}$ culture medium composed of Neurobasal A medium supplemented with $10 \%$ fetal bovine serum, 2\% B-27 (Gibco), 1\% L-glutamine (Sigma-Aldrich, St. Louis, MO), and $1 \%$ antibiotic-antinycotic mixture. Explants were cultured at $37^{\circ} \mathrm{C}$ with $5 \% \mathrm{CO}_{7}$ in a hamidified atmosphere. The eulture medium level was maintained in contact with the support membrane beneath the explant and changed with freshly prepared, wamed medium on days 1. 3 , 5 , and 7, Specimens were collected at culture days 3, 6, and 9. Freshly detached neuroretinas were also obtained for normal morphologic evaluation.

Mononuclear fraction amaction and addition: Blood from the marginal vein of each animal was collected to prepare the mononuclear fraction (MNF) from which macrophages were derived. The blood was transported to the laboratory in beparinized collection tubes (Heparina Leo 1\%; Byk Leo, Madrid, Spain), and MNF extraction begua $30 \mathrm{~min}$ after collection. Next, $6 \mathrm{ml}$ heparinized blood was diluted $1: 1$ in 0.1 M filtered phosphate buffered saline (PBS, pH 7.4) and mixed by inversion. Histopaque ${ }^{*}-1077$ (Sigma-Aldrich) was used to separate the MNF. Histopaque ${ }^{*}$ was deposited in a centrifuge tube, and two volumes of blood-PBS mixture were added. Tubes were centrifuged at $400 \mathrm{xg}$ for $30 \mathrm{~min}$, obtaining an opaque interface containing the MNF. The plasma was removed and then the MNF was taken, leaving the erythrocytes and polymorphouuclear letukocytes in the tube. The MNF was placed into a clean centrifuge tube and washed in $10 \mathrm{ml}$ PBS by centrifugation at $250 \mathrm{xg}$ for $10 \mathrm{~min}$, prodricing a pellet at the bottom of the tube. The supematant was removed and $200 \mu \mathrm{l}$ of retinal culture medium was directly added over the pellet to reconstitute it. The cell count, made with a Necubaner counting chamber, was about $15 \times 10^{d}$ eells $\mathrm{ml}$. Cell viability, determined by the trypan blue dye exclusion method [19], was always greater than $90 \%$.

At day 0,20 ml of the MNF cell suspension were added over each explant. To ensure that mononncleas cells were deposited and remained on the retina during the culture, we placed a plastic cylinder, which had an inner diameter of $4 \mathrm{~mm}$, on each retina, and deposited the MNF into it. To verify the presence of monosytes in the MNF, we put a drop on a glass slide, which was then smeared and air-dryed. The slide was stained by the Giemsa method [20] and examined under light microscopy. To verify the survival of macrophage-like cells, we cultured the remaining MNF in $3 \mathrm{ml}$ of retinal culture medium. After 2 days of culture, the medium was removed, and the cells were stained with the Giensa method and examined by light mieroscopy.

Light and immanofluonescence microscopy: Specimeas were fixed for a maximum of $6 \mathrm{~h}$ at $4^{\circ} \mathrm{C}$ in $4 \%$ filtered paraformaldehyde (Panreac Química S.A., Barcelona, Spain) in $0.1 \mathrm{M}$ PBS ( $\mathrm{pH} 7.4$ ) and cryoprotected in $30 \%$ saccharose (Panrese Quimica S.A.) at 4 "C for $24 \mathrm{~h}$. Stmples were frozen embedded in Tissue-Tek" O.C.T. " Compound (Sakura Finetek Europe B.V., Zosterwoude, The Netherlands). Next, $12 \mathrm{~mm}$ sections were eut with a cryostat (Leica, Nussloch. Germany) and placed on commercially treated slides (FisherBiotech. Pittsburgh, PA).

A double imusunostaining protocol was performed. The firs stain was for glial fibrillary acidis protein (GFAP), which constitutes the intermediate filaments (IF) that are prominent in Maller sells and astrosytes exhibiting reactive gliosis [21-23]. The secood was for cellular retinaldehyde-binding protein (CRALBP), a retinoid-binding protein implicated in vitamin A metabolism [24]. CRALBP expression is always found in Moller cells and in astrosytes only during the first two postnatal weeks $[24,25]$. Colabeling of cells with both antibodies allowed differentiation of Moller eells from astrocytes [25,26]. Primary antibodies against undiluted, polyclonal rabbit anticow GFAP (DakoCytomation Inc, Carpinteria, CA) incubated for $30 \mathrm{~min}$ at room temperature and 1:1,000 CRALBP (mouse monoclonal antibody [B2]; Abcam ple, Cambridge, UK) incubated overnight at $4^{\circ} \mathrm{C}$ were used. Following primary antibody incubation, seetions were insubated with scsondary antibodies composed of 1:200 dilution each of Alexa Fluor 594 goat antirabbit and Alexa Fluor 488 goat anti-mouse (Molecular Probes, Eugene, CA) respectively for $2 \mathrm{~h}$. Cellular nuclei were stained with $10 \mu \mathrm{g}$ ml 4,6-diamino-2-phenilindole dihydrochloride (DAPI: Molecular Probes) for $10 \mathrm{~min}$. The slides were then coverslipped with 1:1 PBS-glycerol.

For epoxy-resin embedding. specimens were fixed as described in the previous section and dehydrated in graded aleohols. Tissue infiltration was made in graded concentrations of propylene oxide-epoxy resin-Araldite (TAAB, Berks, UK), and finally resin was polymerized at $60{ }^{\circ} \mathrm{C}$ for $24 \mathrm{~h}$. Next, $1 \mathrm{\mu m}$ sections were eut with an ultramicrotome (L.KB, Bromma, Sweden) and mounted oa slides treated with (3-aninopropyl) triethoxy-silane (SigmaAldrich). For light microseope evaluation, sections were stained with toluidine blue and coverslipped with Entellan ${ }^{*}$ (Merek. Darmstadt, Germany). For semithin immunohistological staining. a published method [7] was modified. Resin-embedded seetions were washed in propylene oxide, and epoxy resin was removed in a sodium sthoxide solution. Subsequently, sections were debydrated in praded acetones. Immunostaining was performed as described in the previous section using antibody against GFAP and DAPI dye.

Sections of porcine optic nerve were used as positive controls for anti-GFAP and anti-CRALBP antibodies. Negative controls included substitution of the primary antibody with PBS and secondary antibody onission. Light 


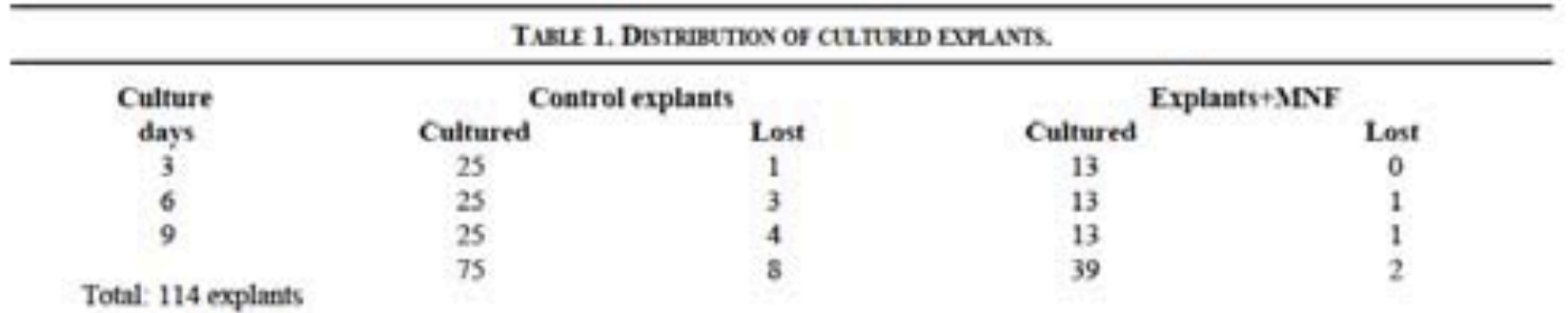

Cotitrol and MNF-stimulated neuroretinal explants were culnued duriag 3, 6 and 9 days. A total of 114 explants wete tased intally. Lost explants were disposed of in the experiment due to an opacification in the first drys of cultire. Monotuelear fraction (MNF) was added to explants in culture at day 0.
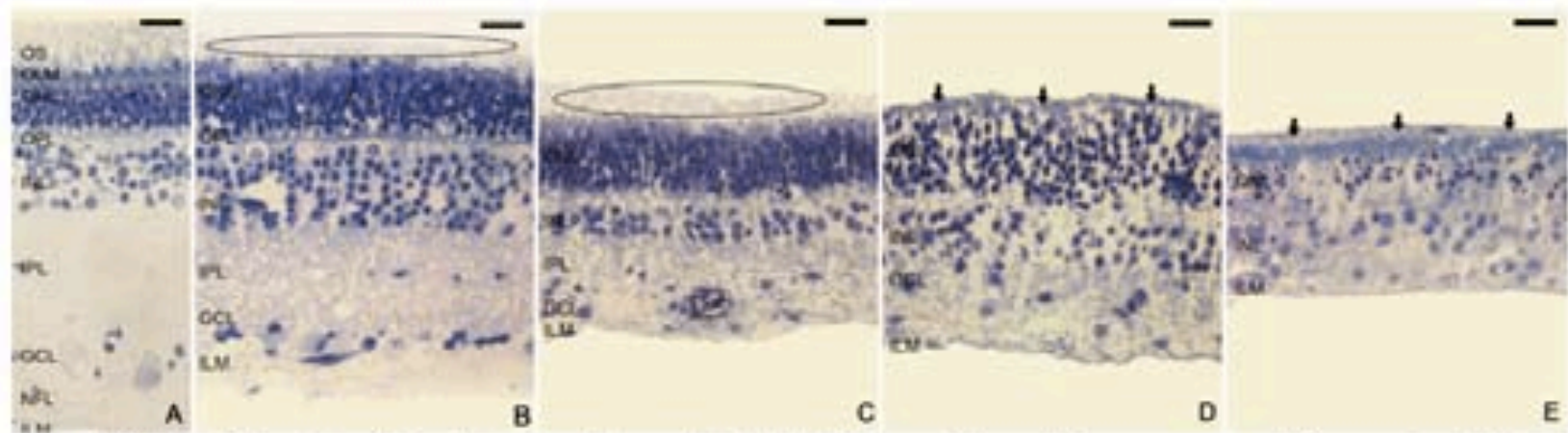

Figure 1. Tolvidine blue staining of semithin sections from coetrol explanss. Neuroretinal momphology was preserved after experimental retinal

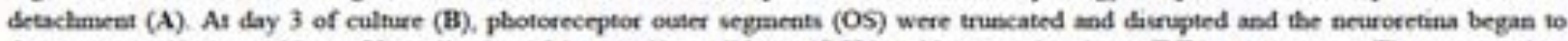
depenerate and become thinner. Vacuolization of the ganplioe cell layer (GCL) and inner maclear layer (INL) was apparent. The ouser muclear layer (ONL) showed 6-7 rows of photoreceptor noclei as in post-detached specimens, but at this time point they were loosely distributed. Fragmented $\mathrm{OS}$ were present in the subeetinal space (ellipisoid area). After 6 days of culnure (C), the anuber of rows of nuclei was reduced in the INL, but remained constant in the ONL. The neuroretinal thickness continued to decrease, mainly dae to narrowing of the plexiform layers. Fragmented $O S$ remained preseat in the subretinal space (ellipsoid asea). Affer 9 days in culture, explants that maintained the tetinal archinecture (D) revealed a lower packing density of cell, and there was a marked redaction in the mumber of nuclei in the INL. The plexiform layers almost disappeared and a tissue layer was present outside the outer limiting menbrane (OL.M; arrows). In explants that showed cellular disorganization (E). nuclei were randomly arranged, appearing outside the $\mathrm{OL}$ M and comprised a new multinuclear tissue layer in the subretinal space (arrows) Conparing (A-E) images, the retinal thinning during the culture is apparent. On days 3,6, and 9, the ONL looked progressively thicker (B-D). Scale bar equals $20 \mathrm{~mm}$. Abbeviations: inner nuclear layer (INL); nerve fiber layer (NFL).

and imanumofluorescence studies were performed with an Axiophot microscope (Zeiss, Oberkochen. Germany) equipped for epifluorescence. Images were captured with a Spot dipital camera \$P402-230 (Diagnostic Instruments, Sterling Heights, MI) and processed with the appropriate software (Spot Advanced Version 3.5.9. for Windows: Diagnostic Instruments). Fluorescence was also detected with a confocal microscope imaging system (Leica TCS SP2; Leica, Wetzlar, Germany) equipped with an Ar-Kr laser. One Airy unit was used, giving an optical slice thicloness less than $0.9 \mathrm{~mm}$. TIFF images were enhanced using Adobe Photoshop software (Version 10.0.1 for Macintosh).

\section{RESULTS}

Control parcine neuroretina in organotypic culthere:

Macroscopic morphology-A total of 75 control explants were cultured for different periods (Table 1). Eight samples lost their transparency in the first days of culture and were discarded. The other explants remained transparent and became thinner during the eotrse of the culture. This reduction of the retinal thickness was more accentuated in the last days, making visible the normal retinal blood vessels at the superficial layers of the explants.

Light mieroscopy-The overall architecture of the neuroretina, including the delicate structures of photoreceptor inner segments (IS) and outer segments (OS), was well preserved immediately after mechanical detachment from the underlying RPE (Figure 1A). At day 3 of culture (Figure 1B), the neuroretina was thinner, and a vacuolization of the ganglion eell layer (GCL) and $\mathrm{NL}$ was apparent, OS were trumeated and disrupted. In sontrast, the IS appeared quite similar to those in the postdetachment specimens, in which the outer nuclear layer (ONL) had 6-7 rows of pbotoreceptor 

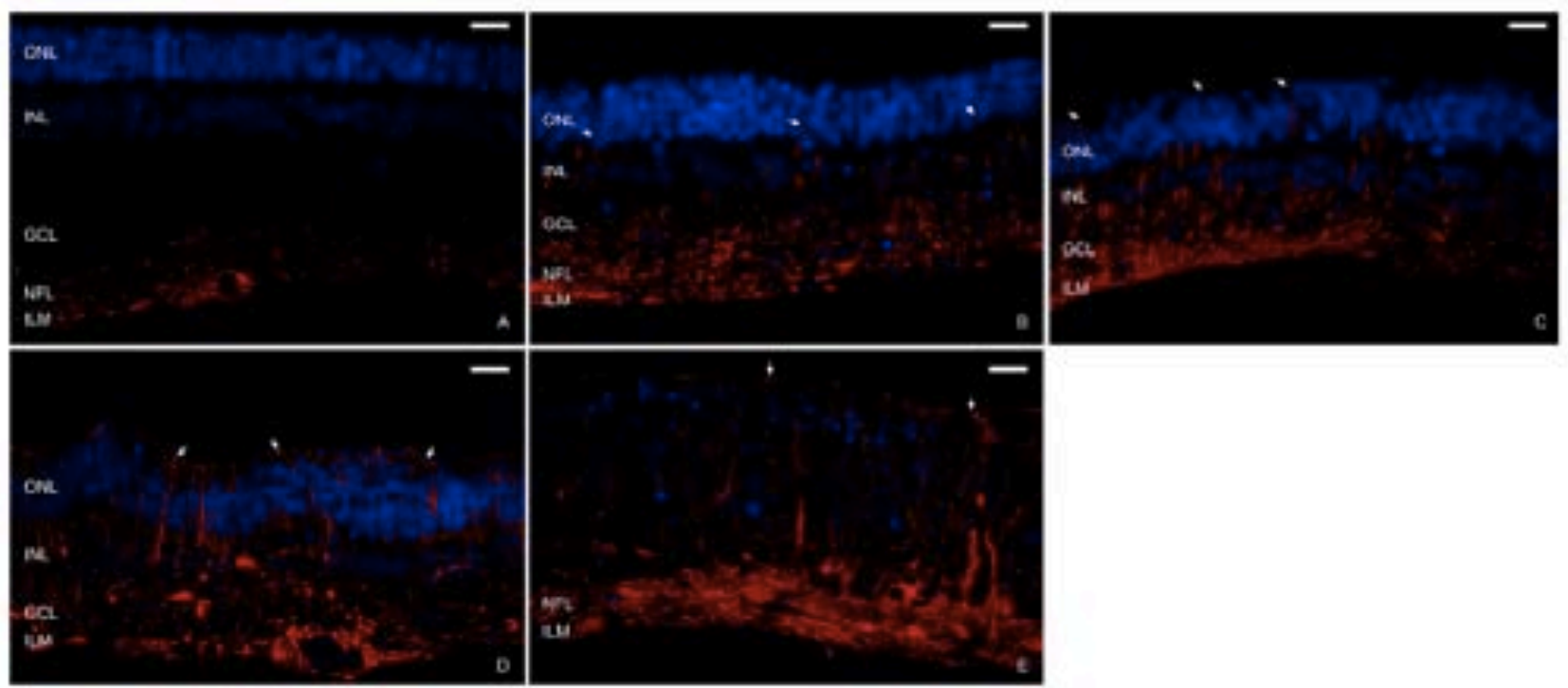

Figure 2. Immunofloorescesce staining of semithin sections from control explants, Antibodies against glal fibrillary acidic protein (GFAP. sed) were taved to ideatify elasl IF. DAPI dye (blue) was uned to Label maelei. In pewly detached sauples (A). GFAP was present in the end feet of Maller cells (uner limiting membrane, ILM) and in astrocytes (berve fiber layer, NFL). The outer nuclear layer (ONL). inner muelent layer (INL), and panglion cell layer (GCL) were identified with DAPI dye. At 3 days of culture (B). GFAP was detectable throughout the Meller cell cytoplasm, from the II.M to the ONL (arrows). After 6 days of culture (C), the Muller cells were wider and their GFAP+ processes reached the outer limiting membrane (OLM, note arrows). Afer 9 days in culture, in explants thant maintained the retinal structure (D)), labeled processes extended beyond the OLM and began to create a continoous layer in the subretinal space (arrows). In samples that lost the characteristic retinal organization (E), naclei of surviving cells and GFAP+ extessions were tandoenly distributed, appearing over the OLM (arrows). Seale bar equals $20 \mu \mathrm{m}$

nuclei that were loosely distributed. The rest of the retinal architecture appeared fairly normal.

After 6 days of culture (Figure 1C), a considerable dininution of the neuroretinal thickness was ayparent, mainly due to the thinning of the plexiform layers. The number of rows of nuclei was remarkably redueed in LNL but remained constant in ONL. At culhure days 3 and 6 , fragmented $O S$ were present in the subretinal space (Figures 1B,C, ellipsoid area). On days 3, 6, and 9, the ONL looked progressively thicker (Figures 1B-D).

After 9 days in culture, 9 of the surviving explants maintained similar retinal architecture as specimens incubated for 6 days (Figure ID). The sells were less densely packed. and the INL showed a marked reduction in the number of nuclei. The plexiform layers had almost disappeared and a tissue layer was present outside the OLM. In addition. 12 of the other surviving explants displayed cellular disorganization (Figure 1E), losing the typical retinal structure. Nuclei were randomly arranged across the neuroretina and some were located outside the OLM, comprising a new multinuclear tissue layer oriented parallel to the photoreceptor surface.

Immunofluorescence microscopy - In semithin sections processed for fluorescence microsoopy, the ONL, $\mathrm{NL}$, and GCL were identified by DAPI staining. In freshly detached specimens (Figure 2A), GFAP+ IF were only detectable in the end feet of Muller cells at the ILM, and in astrocytes located in the nerve fiber layer (NFL).

At 3 days of culture (Figure 2B). GFAP reactivity incrensed compared to that in newly detached neuroretinas. Anti-GFAP and DAPI colabeling showed that during the culture period, the immumoreactive labeling extended throughout the length of the Milller cells from the IL.M to the ONL. After 6 days of culture (Figure 2C), the cytoplasm of Moller cells was wider and the GFAP+ processes reached the OLM and extended beyond this structure.

After 9 days in culture, GFAP immunoreactivity reached its maximum in this experiment. In explants that maintained the retinal structure (Figure 2D), labeled extensions crossed the OLM and began to create a continnous layer parallel to that membrane. At this time some samples had lost the characteristic retinal organization (Figure 2E). In these explants, nuclei of surviving cells and GFAP+ extensions were nundomly distributed. These also appeared outsjde the OLM.

To corroborate Miller cell identification by anti-GFAP staining and to allow differentintion of these cells from astrocytes, we colabeled cryosections of explants on day 6 of culture with both anti-GFAP and anti-CRALBP antibodies (Figure 3). Confocal images revealed that anti-CRALBP labeling was localized to the cytoplasm and extensions of the Muller cells, and it was more concentrated at the neuroretinal 


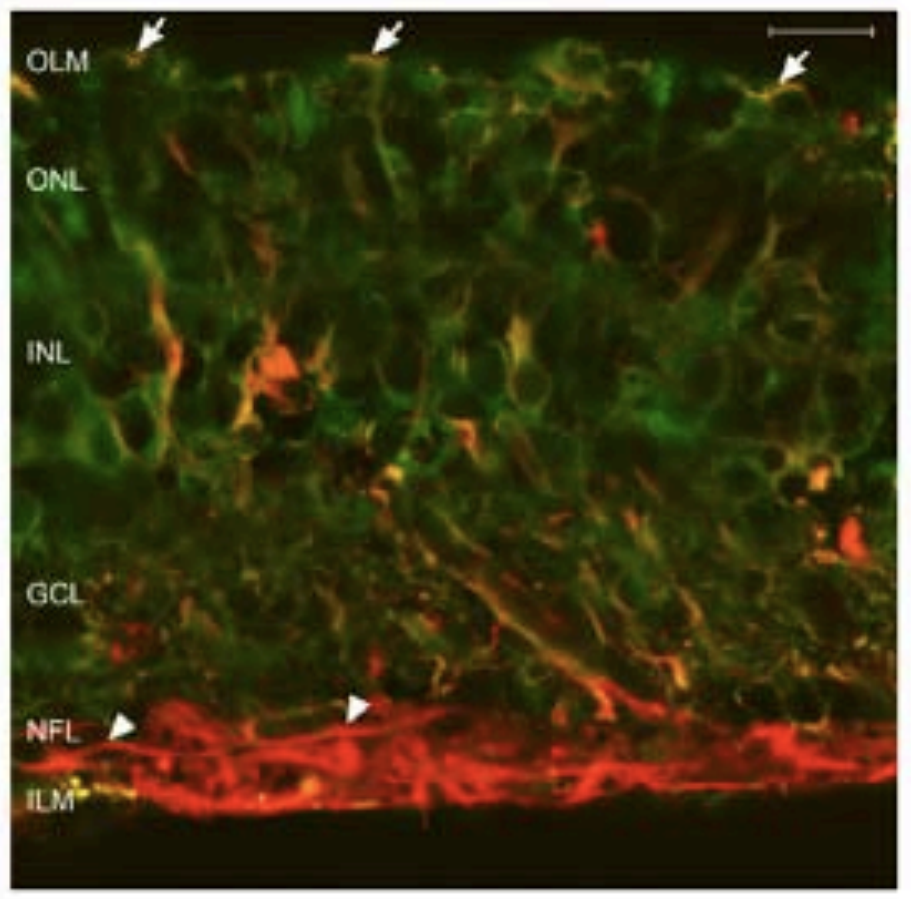

Figure 3. Inmmanofluorescence staining of cryosections from 6 day coutrol explants. As seen in confocal images of cryostat sections, antibodies against glaal fibrillary acidic proten (GFAP. red) identified glial intermediate flararnts (IF), and antiloodes against cellular retinaldehyde binding protein (CRALBP; green) identified a retinoid. binding protrin present in Moller cells. CRALBP labeling was mote concentrated at the neuroretinal outer Layers. Colocalization of both nntibodies (vellow) marked Muller cells GFAP + In coetrol explants, only some Muller cells showed GFAP expression in the cytoplasm that reached the outer limiting membrane (OLM: arrows). Astrocyte cell bodies and GFAP+ extensions wese located aloag the nerve fiber layer (NFL; arrowheads). Scale bar equals $20 \mu \mathrm{m}$. Abbreviatioes: ganglion cell layer (GCL). imner limuting membrane (II.M); inner nuclear layer (INL); outer nucleser layer (ONL).

outer layers. A small number of these cells were GFAP+ and reached the OLM. Cell bodies and GFAP+ extensions of astrocytes were localized within the NFL.

Variations in the porcine neuraretina onganotypic culture after MNF addirion:

Macroscopic morphology-A total of 39 explants were cultured in the presence of the MNF for different periods (Table 1). Two of the samples lost transparency in the first days of eulture and were disearded. During the eulture, viable explants showed the same aforedescribed evolution in controls.

Light microscopy - Histological smears of MNF stained with the Giemsa method showed abundant monosytes and lymphocytes. After 2 days in culture with the retinal mediusn, high numbers of macrophage-like sells appeared in the MNF culture.

Neuroretinal explants cocultured with MNF did not reveal any noticeable histological changes at 3 and 6 days of culture in comparison with controls. However, all of the explants cultured for 9 days with MNF showed sellular disorganization and larger tissue invasion of the subretinal space accompanied by cellular nuclei (Figure 4).

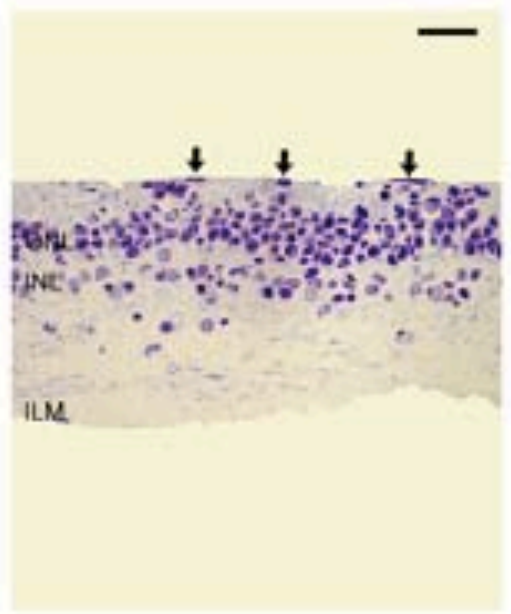

Firure 4. Tohnidme bloe staining of semithin secticens from explants cocultured with the mononsclear fraction. Explants cultured 9 days with the monomuclear fraction (MNF) had mote evident cellular disorganization and large multinuclear tissue invasion of the subretinal space (arrows). Scale bar equals 20 um. Abbreviations: inner auclear layer (TNL); inner limiting membeane (ILM); outer nuclear layer (ONL) 

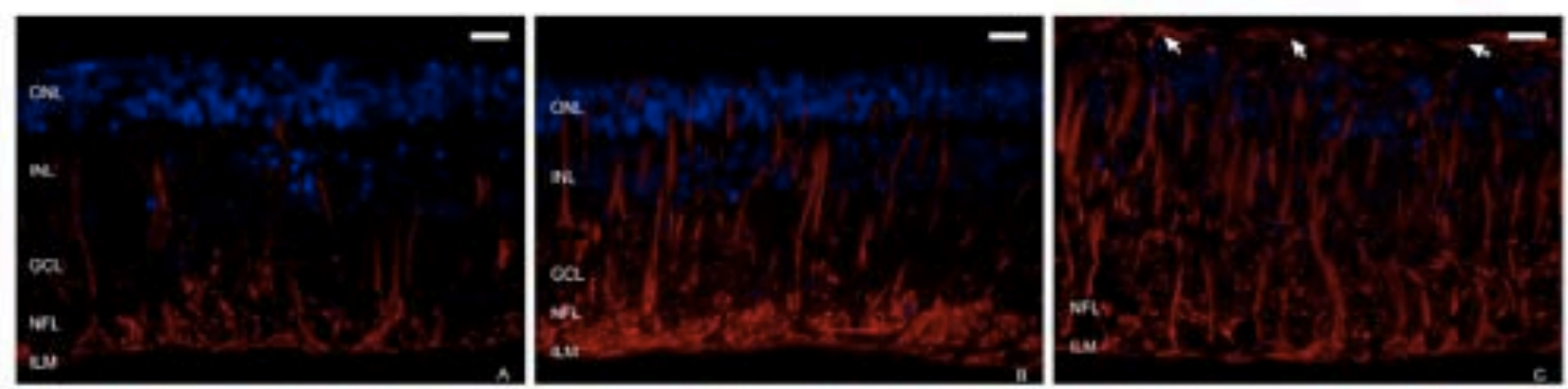

Figure S. Inmunofluorescence staining of semithin sections from explants cocultured with the monoenclear fraction. Antibody against glial Gibrillary acidie protein (GFAP, red) and DAPI dye (blue) were uved. At 3 (A), 6 (B), and 9 (C) days of culture, the Muller cells were wider and more positive for GFAP than controls. After 9 days in culture (C), numerous Maller cell GF $A$ P ' processes invaded the subretinal space, distribusted in several fibrous layers (arrows). Scale bar: $20 \mu \mathrm{m}$. Abbreviations: GCL is ganglion cell layer; ILM is inner limiting membrane; DNL. is inser meleas layer, NFL: nerve fiber layer: ONL, is outer nselear layer.

Immunofuorescence microscopy-

Imumumohistochenical labeling of semithin sections revealed increased GFAP+ reactivity and significant changes in the Maller eells at all eulture periods. In the presence of MNF, it was apparent that more Miller eells were wider and were more immunoreactive than the coutrols (Figures $5 \mathrm{~A}-\mathrm{C}$ ). In addition. at culture day 9 (Figure SC), multiple labeled processes invaded the subretinal space and were distributed in several fibrous layers. There was also an increase in GFAP labeling intensity in the NFL and GCL.

Cryosections of explants cocultured with MNF for 6 days were examined by confocal microscopy (Figure 6). Colabeling with both anti-GFAP and anti-CRALBP revealed an increased expression of GFAP and a decreased CRALBP expression in the neuroretinal extemal layers. Additionally. Muller cell processes crossed the OLM. The cell bodies of GFAP+ astrocytes remained in the NFL, but the extensions crossed the neuroretinal thickness to reach the outer layers.

\section{DISCUSSION}

While the organotypic culture of the neuroretina was originally described to follow cellulas and cytoskeletal changes during the culture period [5,27]. this model also reprodueed some of the cellular changes revealed in experimental RD [2]. Thus, we have used it to analyze the in vitro response of Moller cells to a mononuclear blood fraction as a source of macrophages. The porcine neuroretina was selected because it has many similarities with the human one. These include retinal size, extension, strocture, and ultrastructure [28]. Additionally, the holoangiotic vaseulature pattern and the distribution of immmocompetent cells [29, 30] are quite similar to that of the human eye.

In control cultures, the most important light microscopy findings were early os degeneration. ganglion cell layer vacuolization, plexiform layer shortening, cellular death, and finally cellular debris and nuclei appearing over the OLM. These changes were similar to the development of stubretinal membranes found in RD [2]. Noticenble retinal thinning also oceurred during the culture. Similar observations have also been found in other models of RD, both in vivo and in vitro [2,5,31,32]. At 3 and 6 days of culture, OS fragments present in the subretinal space were diminished, similar to that which oceurs during longer term RD. In vivo, this is probably the result of phagocytosis by RPE cells and macrophages that invade the subretinal space [31]. The thickening of the ONL. can be attributed to regional differences of the explants. Additionally, it could be due to Muller cell gliosis and growth of processes that fill the space left by dying neurons. This gliosis causes a disorganization of the ONL that reduces the packing density of the sells and results in ONL thickening.

Inmunofluorescence staining of freshly detached sauples was consistent with previous studies $[2,27,32,33]$. However, another porcine neuroretinal study found that GFAP+ staining was distributed from the NFL to the ONL [5]. We found rapid increases in GFAP expression during the first 3 days of culture, reaching the ONL. These changes were probably associated with photoreceptor cell death that occurs after RD [34]. Subsequently, the expression of the GFAP IF proteins contimued to increase in the Maller cell cytoplasm. but the rate of increase diminished. At 6 days, GFAP expression in our cultures was similar to that seen in other studies [2.5]. Finally. eytoplasmic extensions of the Moller cells surrounded photoreceptors IS and invaded the subretinal space, establishing a newly formed tiscte at 9 days of culture. This tissue appeared similar to the subretinal menbranes developed between 7 and 28 days after experimental RD in cats $[2,4]$ and in porcine neuroretina organotypic culture after 10 days [5]. Previous studies of human specimens [6,8,10] revealed the same increases in GFAP throughout Moller cells.

In explants cocultured with MNF, the glial cell thickness appeared to increase. This needs to be confirmed in quantitative follow-up studies. In addition to the elongation and overgrowth, Muller cells underwent a greater degree of hypertrophy and hyperplasia in the subretinal space when the explants were cocultured with MNF. This response was likely due to interactions of Müller cells with lymphocytes as well 


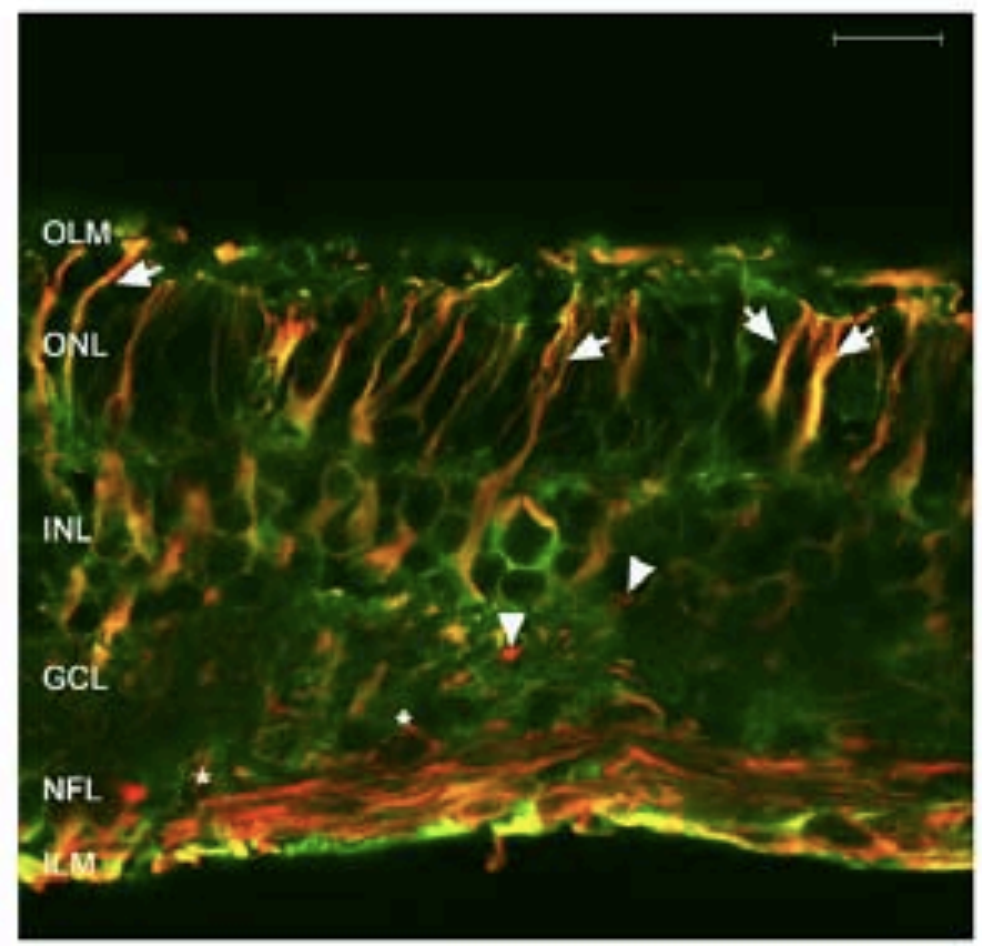

Figure 6. Immunofluorescence staining of cryosections from 6 day cocultured explantx. Antzbedies against glial fitrillary acidic protein (GFAP, red) and cellular setinsidehyde-binding protein (CRALBP: green) were used Confocal images revealed an increased expression of GFAP and a decreased CRAL BP expressioe in the neurosetinal external layers. Muller eell processes crossed the outer limining membrane (OLM: arrows). The cell bodies of GFAP+ astrocytes remained in the gerve fiber layer (NFL; asterisk), but the extensions crossed the neuroretims, seaching the outer layers (arrowhesds) Scale bar equals $20 \mu \mathrm{m}$. Abbreviations. ganglion cell layer (GCL): inner lumitug membrane (II.M); inatr nucleat layer (INL); outer noclear layer (ONL).

as macrophage-like cells [13] that can induce a retinal reactive gliosis. In this model. MNF was the most likely source of the macrophages as these cells are abundant when MNF were cultured alone. Besides Muiller cell modifications, astrocytes also underwent some changes, such as growth of extensions that invaded the neuroretinal outer layers by 6 days of culture.

At 9 days of sulture, growth of inmunoreactive Moller cells processes ocerpied the space left by dying neuroens. At this time, cells seemed to adhere to one another, forming a protective whole that included the rest of surviving neurons. The immunofluorescence and histology images at 9 days of culture with the MNF mimicked the findings obtained in human PVR retineetomy specimens [7,9]. showing grester retinal structure disorganization, loss of neuronal nuclei, and GFAP+ reactive gliosis than prior $R D$ models [2.5.31.32].

Previons studies indicated that the breakdown of the blood-ocular barrier and the separation between $O S$ and RPE that occurs in $\mathrm{RD}$ are the principal stimuli for the migration of macrophage-like cells into the retina [35-37]. These cells probably originated from blood monocytes [9] and RPE dedifferentiation [36.38]. Furthermore, apoptotic photoreceptors attract macrophages [39], and in vitro studies demonstrated that macrophage-like cells could be activated after interaction with the RPE $[17,40]$. In the activated state, these inflammatory cells can release multiple proangiogenic and proinflammatory eytokines. One of these cytokines, TNF $\alpha$, binds to receptors on Muller cells [41] and probably activates them [13]. In addition. TNF $\alpha$ activates microglia and astrocytes in the central nervous system [42].

In sumamary, we developed an in vitro neuroretina model of Müller eell gliosis that is enhaneed by external addition of masrophages. The cellular iuteractions present in this model could be used for phammacological assays, testing the efficacy of drugs that can inhabit the retinal searring process. Cytokines released by activated macrophages will be a target for future studies.

\section{ACKNOWLEDGMENTS}

We thank Nicolas Cuenca (University of Alicante, Spain) for his advice and assistance in confocal microscopy, Elena Vecino (University of Pais Vasco, Spain) for helping us with the development of the retinal organotypic culture, and Luis Santiago (University of Valladolid, Spain) for technical assistance with semithin section protocols. This study was supported in part by a grant "Proyecto de Investigación en Biomedicina de la Jumta de Castilla y León (Expediente: SAN/ 1052/VA17/05)." Portions of this research were presented at 
the anutual meeting of the Association for Research in Vision and Ophthalmology (ARVO), Fort Lauderdale, Florida, April 26-May 1, 2008.

\section{REFERENCES}

1. Ramóa y Cajal S. La rétine des vertébrés. Cellule 1893: 9:120-246

2. Fasber SK, Lews GP. Maller cell and aeurensl remodeling in retinal detachment and reattachment and their potential convequences for visual secovery a review and reconsideration of recent dats. Vision Res 2003; 43-887.97. [PMID: 12668058]

3. Lews GP, Fisher SK. Maller eell outgrowth after retinal detachment. association with eone photoreceptors. Invest Opthalmol Vis Sci 2000; 41:15:42-5. [PMW; 10798674]

4. Lewis GP. Matsumoto B. Fisher SK. Changes in the organization and expression of cytoskeletal proteins during retinal degeneration induced by retinal detachment. Invect Optathalmol Vis Sci 1995: 36-2404-16. [PMID: 7591630]

5. Winkler J, Hagelstem S, Rohde M, Lequa H. Cellulat and cytoskeletal dynamics within organ cultures of porcine neurosetina. Exp Eye Res 2002: 74:777-88. [PMDD 12126951]

6. Lewis GP, Sethi CS, Canter KM, Charteris DG, Fisher SK Microglial cell activation following retinal detachusent a comaparison between species. Mol Vis 2005; 11:491-500. [PMID: 16052164]

7. Charteris DG, Downie J. Aylward GW, Sethi C. Luthert P Intraretinal and periretinal pathology in anterior protiferative vitreoretinopathy. Graefes Arch Clin Exp Ophthalmol 2007, 245-93-100. [PMID: 16612635]

8. Okada M, Matsamara M, Ogino N. Honda Y. Maller cells in detached human retina express glial fibrillary acidic protein and vimentin. Graefes Arch Clin Exp Opbthalmsol 1990: 228.467.74. [PMID: 2227494]

9. Pastor JC, Mendez MC, de in Fuente MA, Coco RM, GarciaArumi J. Rodriguez de la Rua E. Fernandez N, Saornil MA. Ginyoso MJ. Intraretinal inmonohistochenistry findings in proliferative vitreocetinopathy with retinal shortening Ophthalmic Res 2006: 38:193-200. [DMD: 16679807]

10. Sethi CS, Lewis GP. Fisher SK. Leitser WP, Mann DL. Luthen PJ, Charteris DG. Glial remodeling and neural plasticity in human retinal detachment with proliferative vitreatetinopatby. Invest Optribalmol Vis Sa 2005; 46:329-42. [PMU: 15623793]

11. Martin F. Pastor JC, De La Rua ER. Mayo-Iscar A. GaseiaArumi J.Martinez V. Fernundez N, Smomil MA Proliferative vitreoretinoputhy; cytologic findings in vitreous sumples. Optrthalmic Res 2003; 35:232-8. [PMID; 12815199]

12. Yang $P$, de Vos AF, Kujletra A. Macrophages in the retina of nomal Lesis rats and their dynamics after injection of lipopolysaccharide. Invest Ophthalmol Vis Sa 1996: 37-77-85. [PMID: 8550337]

13. Caicedo A, Espinosa-Heidmann DG, Pina $Y$, Hemandez EP. Cousins \$W. Blood-derived macrophages infiltrate the retina and activate Muller glial eells under experimental choroidal neotascularization. Exp Eye Res 2005; 81:38-47. [PMID: 15978253]
14. Hiscott P. Macrophages in the pathobiology of epiretins membranes: multifuncticanl cells for a multistage process. $\mathrm{Br}$ J Ophthalmol 1993; 77.686-7. [PMID: 8280679]

15. Kirchhof B. Sorgente N Pathogeoesis of proliferative vitreoretinopathy. Modulation of retinal pigment epithelis cell functions by vitreous and macrophages. Dev Ophthalmol 1989: 16:1-53. [PMID: 2676632]

16. Osuský R. Ryan SJ. Retinal piement epithelial cell proliferation: potentiation by monocytes and serum. Graefes Arch Clin Exp Ophthalmol 1996; 234:576-82. [PMaD. 8871154]

17. Osuský R. Malik P. Aurora Y, Ryan SJ, Monocyte-maccophage differentiation induced by coculture of retinal pigment epithelium cells with mooocytes. Ophthalmic Res 1997: 29.124-9. [PMID: 9211464]

18. Toti P, Greco G, Catella AM. Morphological and pathogenetic aspects of proliferative vitreo-retinopachy. $\mathrm{A}$ histological and inumusolistochenical study. Doe Ophthalmol 1994. 88:105-12, [PMD: 7781478]

19. Butler M. Animal cell culnure \& technology. 2nd ed Oxon (UK) Garland Science/BIOS Scientific Publishers: 2004.

20. Freshary RL. Culture of animal cells: a manual of basic technigue. Sth ed. Hoboken (NJ): John Wiley \& Sons, Inc; 2005.

21. Ersenfeld AJ, Bunt-Milam A, Sarthy PV.Muler cell expression of glial fibeillary acidic protein after genetic and experimental photoreceptor degeneration in the rat retina. Invest Ophthalmol Vis Sei 1984, 25:1321-8. [PMD. 6386743]

22. Ekstrom P, Sanyal S, Narfstrom K, Chader GJ, van Veen T. Accumulation of glial fibrillary acidic protein in Maller radeal glia during retimal degeneration. Invest Ophthalmol Vis Sca 1988, 29:1363.71. [PMD: 3417421]

23. Sarthy PV, Fu M. Transcriptional activation of an intermediate flament protein gene in mice with retinal dystrophy. DNA 1989; 8:437-46. [PMU: 2776627]

24. Bunt-Milam AH. Saari JC. Immunecytechemical localizatice of two retinoid-binding proteins in vertebrate retina. J Cell Biol 1983; 97.703-12. [PMID: 6350319]

25. Johnson PT, Geller SF, Lewis GP. Reese BE. Cellular retinaldetyde binding protein in developing retinal astrocytes. Exp Eye Res 1997; 64:759-66. [PMUD: 9245906]

26. Guerin CJ. Wolfshagen RW. Eifrig DE, Anderwon DH Immunecytechemical identification of Muller's glia as a component of human epiretimal membranes. Inves Optathalmol Vis Sci 1990: 31:1483-91. [PMID: 2387681]

27. Allamby D, Foreman D, Casringtoon L, MeLeod D, Boulion M. Cell attachment to, and contraction of, the retina in sitro. Invest Ophthalmol Vis Sei 1997: 38:2064-72. [PMID: 9331270]

28. Hendrickson A. Hicks D. Distribution and densaty of mediumand short-wavelength selective cones in the domestic pig retina Exp Eye Res 2002: 74 435-44. [PMID 12076087]

29. De Schaepdnjver L, Simoens P, Lawwers H, De Geest JP. Retinal vascular patterns in domestic animals. Res Vet Sci 1989: 47:34-42. [PMID: 2772405]

30. Garcia-Layma A, Pastor JC, Saomil MA, Gonzalez G. Porcine model of proliferative vitreoretinopathy with platelets. Curr Eye Res 1997; 16:556-63. [PMID 9192164]

31. Fisher SK, Lewis GP, Linberg KA, Verardo MR. Cellular remodeling in mammalian retina: results from studies of 
experimental retinal detachment. Prog Retin Eye Res 2005 24:395-431. [PMID 15708835]

32 Jackson TL. Hillenkamp J, Willanmson TH. Clarke KW, Alnubarak AI. Marshall I. An experimental model of itsegmatogenous retinal detachment surgical results and glia] cell tesponse. Invest Ophthalmol Vis Sei 2003: 44:4026-34 [PMID 12939325]

33. Indiev I, Uckermann O, Pannicke $T$, Wurm A, Tenckhoff S, Pietsch UC. Reichenbach A. Wiedemsan P. Bringmann A. Uhlmann S. Glial cell reactivity in a porcine model of retinal detachment Invea Oplahalmol Vis Sci 2006; $472161-71$ [PMID: 16639028]

34. Cook B. Lewis GP. Fisher SR. Adler R. Apoptotic photoreceptor degeneration in experimental setina! detachment. Invest Ophthalmol Vis Sci 1995: 36:990-6. [PMID: 7730033]

35. Charteris DG. Hiscott P. Robey HL, Grepor ZJ, Lightman SL. Graesson I Inflammatory cells is prodiferative vitreotetinopathy subretinal membranes. Ophthalmolozy 1993: 100-43-6. [PMD: :5094546]

36. Hasatomi T, Sakamoto T. Sonoda KH, Tsutsuma C, Qhao H. Enaida H. Yamanaka I, Kuboca T, Ishibashi T, Kua S, Susin SA. Kroctart G. Clesance of apophotic plotereceptons elimination of apoptotic debris into the subretinal space and macrophage-mediated phapocytosis via pbosphatidylserine receptor and integrin alphavbeta3. Am J Pathol 2003: 162:1869-79. [PMID 12759244]

37. Jerdan JA. Pepose JS, Michels RG, Hayashi $H$, de Bustros S. Sebag M. Glaser BM. Proliferative vitreoretinopathy membranes. An immunohistochenical study. Ophathalmology 1989; 96 801-10, [PMID 2662102]

38. Charteris DG. Proliferative vitreotetinopathy: pathotrolory. surgical management, and adjunctive treatment. Br J Ophathalmol 1995; 79-953-60. [PMD: 7488586]

39. Hume DA. Ross II. Himes SR, Sasmono RT. Wells CA, Ravar T. The mosonusless phagocyte system revisiad. I Leukoe Bool 2002; 72.621-7. [PMID: 12377929]

40. Osusky R. Malis P. Ryas SJ. Retinal pigment cpithelium cells promote the maturation of monocytes to macrophages in vitro. Ophthalmic Res 1997; 29:31-6. [PMID: 9112264 ]

41. Fontaine V, Mohand-Said S, Hanotean N, Fuchs C, Pfizenmaier K. Eivel U. Neurodegenerative and neuroprotective effects of turnor Necrosis factor (TNF) in retinal inchersia: opposite toles of TNF teceptor 1 and TNF receptor 2 J Neurosci 2002 , 22-RC216, [PMD: 11917000]

42. Npryen VT. Benveniste EN. Critical role of tumor necrosis factor-alpha and NF-kappa B in interferoe-ganama -induced CD40 expression in mactopla/mactophages. I Bool Clom 2002; 277:13796-803. [PMID: 11830590]

The print version of this article was created on 30 November 2008. This reflects all typographical sorrestions and errata to the article through that date. Details of any changes maxy be found in the online version of the article. 